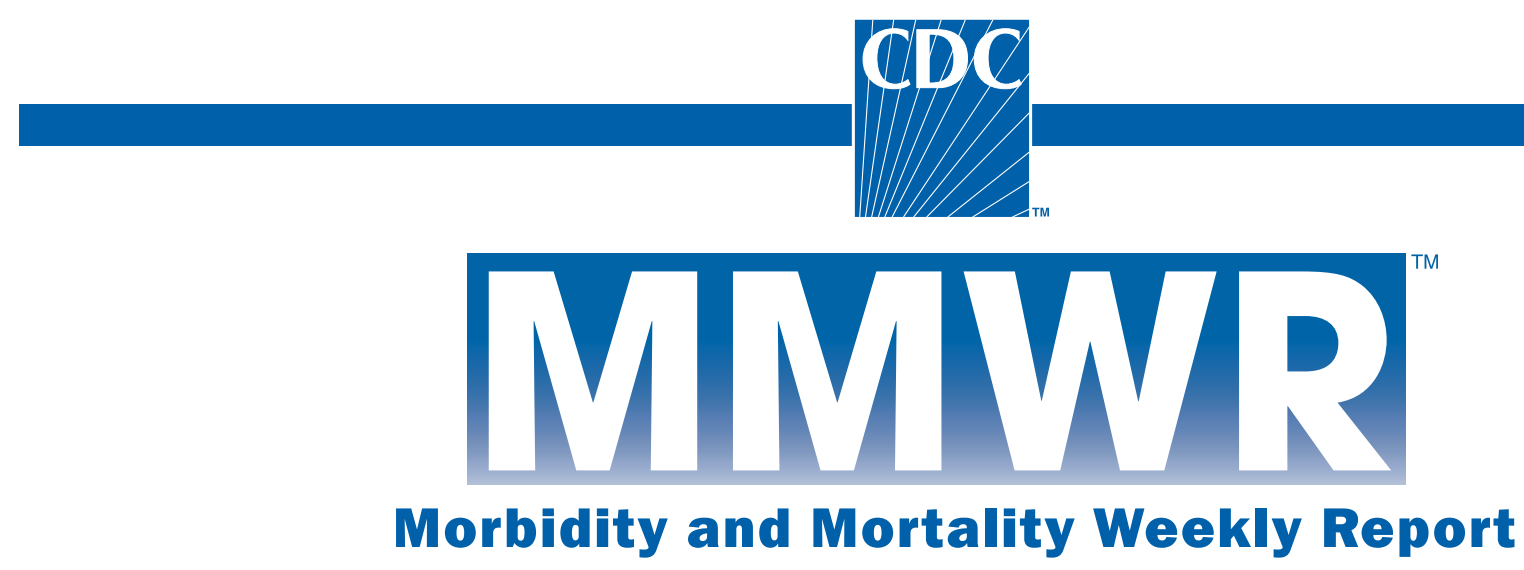

Weekly

September 15, 2006 / Vol. 55 / No. 36

\title{
State-Specific Prevalence of Obesity Among Adults - United States, 2005
}

Obesity, one of the 10 leading U.S. health indicators (1), is associated with increased risk for hypertension, dyslipidemia, type 2 diabetes, coronary heart disease, stroke, and certain cancers (2). A Healthy People 2010 objective is to reduce to $15 \%$ the prevalence of obesity among adults in the United States (objective 19-2) (1). Both national-level data from the National Health and Nutrition Examination Survey (NHANES) (3) and state-level data from the Behavioral Risk Factor Surveillance System (BRFSS) (4) indicate that the prevalence of obesity among adults continued to increase during the past decade. In 2003, one study estimated that statespecific, obesity-attributable medical expenditures ranged from $\$ 87$ million in Wyoming to $\$ 7.7$ billion in California (5). To assess the prevalence of obesity among adults by state and demographic characteristics since 1995, data were analyzed from the 1995, 2000, and 2005 BRFSS surveys. The results of these analyses indicated that $23.9 \%$ of U.S. adults were obese in 2005, and the prevalence of obesity increased during 1995-2005 in all states. To reverse this trend, a sustained and effective public health response is needed, including surveillance, research, policies, and programs directed at improving environmental factors, increasing awareness, and changing behaviors to increase physical activity and decrease calorie intake.

BRFSS data are used to track the prevalence of chronic disease risk factors and monitor progress toward state-specific health objectives. BRFSS is an ongoing, state-based, randomdigit-dialed telephone survey of the noninstitutionalized, U.S. civilian population aged $\geq 18$ years. BRFSS data files are weighted to the respondent's probability of being selected and to the age-, race-, and sex-specific populations from the annually adjusted census for each state. In 2005, response rates*

\footnotetext{
*The percentage of persons who completed interviews among all eligible persons,
} including those who were not successfully contacted. among states ranged from $34.6 \%$ to $67.4 \%$ (median: $51.1 \%$ ), based on Council of American Survey and Research Organizations (CASRO) guidelines. Cooperation rates ${ }^{\dagger}$ ranged from 58.7\% to $85.3 \%$ (median: $75.1 \%$ ). In 1995 and 2000, median CASRO response rates were $68.4 \%$ and $48.9 \%$, and median cooperation rates were $71.3 \%$ and $53.2 \%$, respectively.

Self-reported weight and height were used to calculate body mass index (BMI) (weight $[\mathrm{kg}] /$ height $\left[\mathrm{m}^{2}\right]$ ). Overweight was classified as $\mathrm{BMI} \geq 25.0$, obesity as $\mathrm{BMI} \geq 30.0$, and extreme (class III) obesity as BMI $\geq 40.0 \mathrm{~kg} / \mathrm{m}^{2}$. To be consistent with previous analyses (4), data were excluded if a respondent's weight was $\geq 500 \mathrm{lbs}$ or height was $\geq 7.0 \mathrm{ft}$.

In 2005, among the total U.S. adult population surveyed, $60.5 \%$ were overweight, $23.9 \%$ were obese, and $3.0 \%$ were extremely obese. Obesity prevalence was $24.2 \%$ among men and $23.5 \%$ among women and ranged from $17.7 \%$ among adults aged $18-29$ years to $29.5 \%$ among adults aged $50-59$ years (Table). Among racial/ethnic populations, the greatest obesity prevalence was $33.9 \%$ for non-Hispanic blacks. Overall, age-adjusted obesity rates were 15.6\%, 19.8\%, and 23.7\% for the 1995, 2000, and 2005 surveys, respectively.

\footnotetext{
$\dagger$ The percentage of persons who completed interviews among all eligible persons who were contacted.
}

\section{INSIDE}

988 National, State, and Urban Area Vaccination Coverage Among Children Aged 19-35 Months United States, 2005

993 Public Health Response to Varicella Outbreaks United States, 2003-2004

996 West Nile Virus Activity - United States, January 1-September 12, 2006

997 Notices to Readers

998 QuickStats 
The MMWR series of publications is published by the Coordinating Center for Health Information and Service, Centers for Disease Control and Prevention (CDC), U.S. Department of Health and Human Services, Atlanta, GA 30333.

Suggested Citation: Centers for Disease Control and Prevention. [Article title]. MMWR 2006;55:[inclusive page numbers].

\section{Centers for Disease Control and Prevention}

Julie L. Gerberding, MD, MPH Director

Tanja Popovic, MD, PhD

(Acting) Chief Science Officer

James W. Stephens, PhD

(Acting) Associate Director for Science

Steven L. Solomon, MD

Director, Coordinating Center for Health Information and Service Jay M. Bernhardt, PhD, MPH

Director, National Center for Health Marketing Judith R. Aguilar

(Acting) Director, Division of Health Information Dissemination (Proposed)

\section{Editorial and Production Staff}

Eric E. Mast, MD, MPH

(Acting) Editor, MMWR Series

Suzanne M. Hewitt, MPA

Managing Editor, MMWR Series

Douglas W. Weatherwax

(Acting) Lead Technical Writer-Editor

Catherine H. Bricker, MS

Jude C. Rutledge

Writers-Editors

Beverly J. Holland

Lead Visual Information Specialist

Lynda G. Cupell

Malbea A. LaPete

Visual Information Specialists

Quang M. Doan, MBA

Erica R. Shaver

Information Technology Specialists

Editorial Board

William L. Roper, MD, MPH, Chapel Hill, NC, Chairman

Virginia A. Caine, MD, Indianapolis, IN

David W. Fleming, MD, Seattle, WA

William E. Halperin, MD, DrPH, MPH, Newark, NJ

Margaret A. Hamburg, MD, Washington, DC

King K. Holmes, MD, PhD, Seattle, WA

Deborah Holtzman, PhD, Atlanta, GA

John K. Iglehart, Bethesda, MD

Dennis G. Maki, MD, Madison, WI

Sue Mallonee, MPH, Oklahoma City, OK

Stanley A. Plotkin, MD, Doylestown, PA

Patricia Quinlisk, MD, MPH, Des Moines, IA

Patrick L. Remington, MD, MPH, Madison, WI

Barbara K. Rimer, DrPH, Chapel Hill, NC

John V. Rullan, MD, MPH, San Juan, PR Anne Schuchat, MD, Atlanta, GA

Dixie E. Snider, MD, MPH, Atlanta, GA John W. Ward, MD, Atlanta, GA
Among states in 2005, obesity prevalences ranged from $17.4 \%$ to $30.3 \%$, and prevalence of extreme obesity ranged from $1.8 \%$ to $5.3 \%$. During $1995-2005$, obesity prevalence increased significantly $(\mathrm{p}<0.01)$ in all states. During 1995 2000 , the number of states with obesity prevalence $<20 \%$ declined from 50 states to 28 states (Figure). In 2005, four states (Colorado, Connecticut, Hawaii, and Vermont) still had obesity prevalences $<20 \%$, but 17 states had prevalences $\geq 25 \%$, including three (Louisiana, Mississippi, and West Virginia) with prevalences $\geq 30 \%$ (Figure).

Reported by: HM Blanck, PhD, WH Dietz, MD, PhD, DA Galuska, PhD, C Gillespie, MS, R Hamre, MPH, L Kettel Khan, PhD, MK Serdula, MD, Div of Nutrition and Physical Activity; ES Ford, MD, WS Garvin, AH Mokdad, PhD, Div of Adult and Community Health, National Center for Chronic Disease Prevention and Health Promotion; D Densmore, PhD, EIS Officer, CDC.

Editorial Note: The findings in this report indicate that statelevel prevalences of obesity in adults, based on self-reported weight and height, increased significantly during 1995-2005, moving states farther away from the Healthy People 2010 target of $15 \%$ prevalence of obesity. According to the surgeon general's Call to Action to Prevent and Decrease Overweight and Obesity (G), for obesity prevention and control to be successful, changes that promote recognition of obesity as a public health threat and assist persons in balancing healthful eating with regular physical activity must be made at multiple levels (i.e., individual, family, community, state, and nation) and across multiple sectors (i.e., education, government, and business). The Task Force on Community Preventive Services has identified evidence-based strategies to reduce weight and increase physical activity. For example, seven worksite interventions with both nutrition and physical activity components (e.g., nutrition education, physical activity "prescription," and behavioral skills development and training) were effective, resulting in average weight losses of 4.4-26.4 lbs during a minimum 6-month period (7). In addition, the Guide to Preventive Community Services ${ }^{\S}$ recommends informational, behavioral, social, environmental, and policy approaches to increase physical activity, including school-based physical education and creation of, or enhanced access to, locales for physical activity in the community.

The findings in this report are subject to at least two limitations. First, BRFSS data rely on self-reported weight and height. Study participants, especially in telephone surveys, tend to underreport their weight, overreport their height, or both, leading to underestimation of obesity prevalence (8). According to NHANES, for which measured weight and height are

\footnotetext{
${ }^{\S}$ Available at http://www.thecommunityguide.org/pa.
} 
TABLE. Percentage of adults aged $\geq \mathbf{1 8}$ years who were obese, ${ }^{*}$ by demographic characteristcs — Behavioral Risk Factor Surveillance System, United States, 1995, 2000, and 2005

\begin{tabular}{|c|c|c|c|c|c|c|}
\hline \multirow[b]{2}{*}{ Characteristc } & \multicolumn{2}{|c|}{$1995(n=110,252)$} & \multicolumn{2}{|c|}{$2000(n=172,157)$} & \multicolumn{2}{|c|}{$2005(n=333,730)$} \\
\hline & $\%$ & $\left(99 \% \mathrm{Cl}^{\dagger}\right)$ & $\%$ & $(99 \% \mathrm{Cl})$ & $\%$ & $(99 \% \mathrm{Cl})$ \\
\hline Total & 15.3 & $(14.8-15.7)$ & 19.8 & $(19.4-20.2)$ & 23.9 & $(23.5-24.2)$ \\
\hline Men & 15.6 & $(14.8-16.4)$ & 20.2 & (19.5-20.9) & 24.2 & (23.6-24.8) \\
\hline Women & 14.9 & $(14.3-15.5)$ & 19.4 & (18.8-19.9) & 23.5 & $(23.1-24.0)$ \\
\hline \multicolumn{7}{|l|}{ Age group (yrs) } \\
\hline $18-29$ & 10.2 & $(9.3-11.1)$ & 13.5 & $(12.7-14.4)$ & 17.7 & $(16.7-18.7)$ \\
\hline $30-39$ & 14.3 & $(13.4-15.3)$ & 20.2 & $(19.2-21.1)$ & 24.4 & (23.5-25.3) \\
\hline $40-49$ & 17.9 & $(16.7-19.0)$ & 22.9 & (21.8-23.9) & 26.5 & (25.6-27.3) \\
\hline $50-59$ & 21.6 & $(19.6-23.5)$ & 25.6 & (24.4-26.8) & 29.5 & $(28.6-30.4)$ \\
\hline $60-69$ & 19.4 & (18.0-20.8) & 22.9 & (21.6-24.2) & 28.1 & $(27.1-29.0)$ \\
\hline$\geq 70$ & 12.2 & $(11.1-13.2)$ & 15.5 & $(14.4-16.5)$ & 18.3 & $(17.5-19.1)$ \\
\hline \multicolumn{7}{|l|}{ Race/Ethnicity } \\
\hline Non-Hispanic white & 14.5 & $(13.9-15.0)$ & 18.5 & $(18.0-18.9)$ & 22.6 & $(22.2-23.0)$ \\
\hline Non-Hispanic black & 22.7 & (21.1-24.3) & 29.3 & (27.8-30.8) & 33.9 & (32.5-35.2) \\
\hline Hispanic§ & 16.8 & $(14.5-19.0)$ & 23.4 & $(21.5-25.4)$ & 26.5 & $(24.9-28.1)$ \\
\hline Other & 9.7 & $(7.6-11.8)$ & 12.0 & $(10.3-13.8)$ & 16.0 & $(14.4-17.6)$ \\
\hline
\end{tabular}

${ }^{*}$ Persons with a body mass index (BMI) of $\geq 30.0$; self-reported weight and height were used to calculate BMl $\left(\right.$ weight $[\mathrm{kg}] / \mathrm{height}\left[\mathrm{m}^{2}\right]$ ).

†Confidence interval.

$\S$ Might be of any race.

used for an adult sample aged $\geq 20$ years, the prevalence of obesity among U.S. adults overall was $32.2 \%$ during $2003-$ 2004 (3), approximately one third greater than the $23.9 \%$ prevalence reported in the 2005 BRFSS survey. Second, persons who use only cellular telephones or are without land-line telephones are not included in BRFSS surveys. Persons with no telephone might be of lower socioeconomic status (9), a factor associated with obesity (10); exclusion of these persons might result in underreporting of obesity prevalence.

Multiple CDC programs address prevention of obesity through nutrition and physical activity. Specifically, CDC's Nutrition and Physical Activity Program to Prevent Obesity and Other Chronic Diseases works collaboratively with state health departments to implement and evaluate interventions to increase physical activity and improve nutrition. The Steps to a HealthierUS program established by the U.S. Department of Health and Human Services in 2003 and overseen by CDC provides funding to 40 communities nationwide to use evidence-based strategies to prevent and reduce the burden of obesity. CDC's Coordinated School Health Program works through state education and health agencies to improve nutrition and increase physical activity in schools.

The continued increase in obesity prevalence underscores the need for additional measures to educate and motivate persons to make healthier choices and to establish social and physical environments that support those choices. To reduce obesity in the United States, an effective public health response will require a robust combination of policies, programs, and supportive environments created through the combined activities of health-care agencies, government, media, business and industry, communities, schools, families, and individuals. In addition, monitoring and evaluation systems are needed to ensure effectiveness of both new and existing interventions and to validate their widening use.

\section{Acknowledgment}

The findings in this report are based, in part, on data provided by BRFSS state coordinators.

\section{References}

1. US Department of Health and Human Services. Healthy people 2010 (conference ed, in 2 vols). Washington, DC: US Department of Health and Human Services; 2000. Available at http://www.health.gov/ healthypeople.

2. National Heart, Lung, and Blood Institute. Clinical guidelines on the identification, evaluation, and treatment of overweight and obesity in adults: the evidence report. Bethesda, MD: US Department of Health and Human Services, National Institutes of Health; 1998. Available at http://www.nhlbi.nih.gov/guidelines/obesity/ob_gdlns.htm.

3. Ogden CL, Carroll MD, Curtin LR, McDowell MA, Tabak CJ, Flegal KM. Prevalence of overweight and obesity in the United States, 19992004. JAMA 2006;295:1549-55.

4. Mokdad AH, Serdula MK, Dietz WH, Bowman BA, Marks JS, Koplan JP. The spread of the obesity epidemic in the United States, 19911998. JAMA 1999;282:1519-22.

5. Finkelstein EA, Fiebelkorn IC, Wang G. State-level estimates of annual medical expenditures attributable to obesity. Obes Res 2004; 12:18-24.

6. US Department of Health and Human Services. The surgeon general's call to action to prevent and decrease overweight and obesity. Rockville, MD: US Department of Health and Human Services, Public Health Service, Office of the Surgeon General; 2001. Available at http:// www.surgeongeneral.gov/topics/obesity.

7. CDC. Public health strategies for preventing and controlling overweight and obesity in school and worksite settings: a report on recommendations of the task force on community preventive services. MMWR 2005;54(No. RR-10). 
FIGURE. Percentage of adults aged $\geq 18$ years who were obese, * by state - Behavioral Risk Factor Surveillance System, United States, 1995, 2000, and 2005

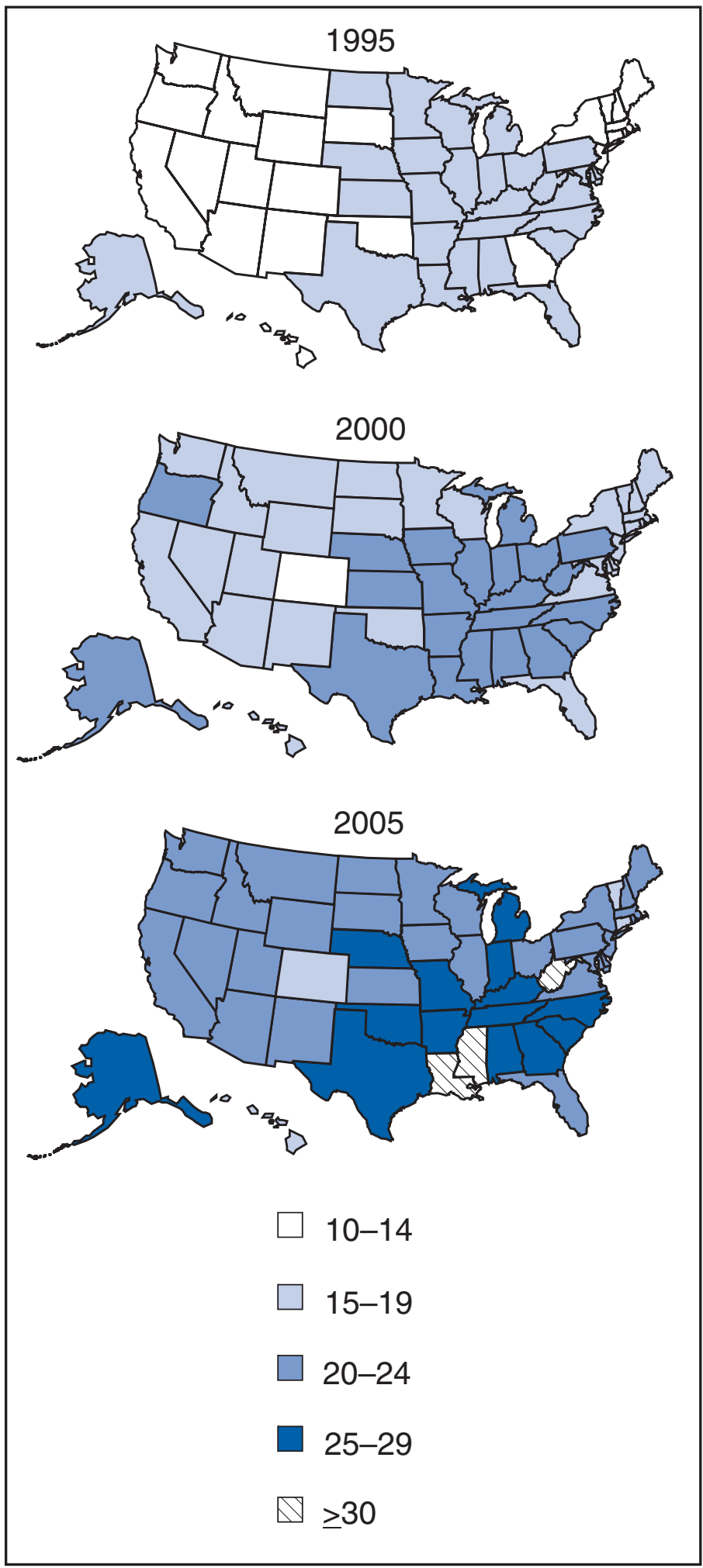

* Persons with a body mass index (BMI) of $\geq 30.0$; self-reported weight and height were used to calculate BMl (weight $[\mathrm{kg}] /$ height $\left[\mathrm{m}^{2}\right]$ ).
8. Ezzati M, Martin H, Skjold S, Vander Hoorn S, Murray CJ. Trends in national and state-level obesity in the USA after correction for selfreport bias: analysis of health surveys. J R Soc Med 2006;99:250-7.

9. Aday LA. Designing and conducting health surveys: a comprehensive guide. San Francisco, CA: Jossey-Bass Publishers; 1989:79-80.

10. Banks J, Marmot M, Oldfield Z, Smith JP. Disease and disadvantage in the United States and in England. JAMA 2006;295:2037-45.

\section{National, State, and Urban Area Vaccination Coverage Among Children Aged 19-35 Months - United States, 2005}

The National Immunization Survey (NIS) provides vaccination coverage estimates among children aged 19-35 months for each of the 50 states and selected urban areas.* Findings from the $2005 \mathrm{NIS}^{\dagger}$ include nationwide increases in coverage with $\geq 3$ and $\geq 4$ doses of pneumococcal conjugate vaccine (PCV) and continued high levels of coverage for the other recommended vaccines and vaccine series. In addition, no racial/ethnic disparities in coverage estimates were observed in the 4:3:1:3:3:1 ${ }^{\S}$ vaccine series, the recommended series for children aged 19-35 months that includes DTP/DT/DTaP; poliovirus vaccine; measles, mumps, and rubella vaccine (MMR); Haemophilus influenzae type b vaccine; hepatitis B vaccine; and varicella vaccine. An important accomplishment indicated by the 2005 NIS data is the achievement of $>50 \%$ coverage for the full series of PCV ( $\geq 4$ doses) and $>80 \%$ coverage for $\geq 3$ doses within 5 years after being added to the U.S.-recommended childhood immunization schedule in

\footnotetext{
* The 28 areas separately sampled for the 2005 NIS included 23 oversampled in previous years (Jefferson County, Alabama; Maricopa County, Arizona; Los Angeles County, California; District of Columbia; Duval County, Florida; Fulton and Dekalb counties, Georgia; Chicago, Illinois; Orleans Parish, Louisiana; Baltimore, Maryland; Detroit, Michigan; Newark, New Jersey; New York, New York; Cuyahoga and Franklin counties, Ohio; Philadelphia County, Pennsylvania; Davidson and Shelby counties, Tennessee; Bexar, Dallas, and El Paso counties, and Houston, Texas; King County, Washington; and Milwaukee County, Wisconsin), and five areas oversampled for the first time (Alameda and San Bernardino counties, California; Denver-Tri County, Colorado, consisting of Adams, Arapahoe, Denver, and Douglas counties; St. Louis City and County, Missouri; and Clark County, Nevada). Although Orleans Parish, Louisiana, was initially oversampled in 2005 , estimates are not available because of interruptions in telephone service, movement of the population, and difficulty locating providers in the aftermath of Hurricane Katrina.

$\dagger$ During the 2005 reporting period, NIS included children born during February 2002-July 2004.

$\$ \geq 4$ doses of diphtheria and tetanus toxoids and pertussis vaccines, diphtheria and tetanus toxoids vaccine, or diphtheria and tetanus toxoids vaccine and any acellular pertussis vaccine (DTP/DT/DTaP); $\geq 3$ doses of poliovirus vaccine; $\geq 1$ dose of MMR vaccine; $\geq 3$ doses of Haemophilus influenzae type $b$ vaccine; $\geq 3$ doses of hepatitis B vaccine; and $\geq 1$ dose of varicella vaccine.

'Diphtheria and tetanus toxoids and pertussis vaccines, diphtheria and tetanus toxoids vaccine, or diphtheria and tetanus toxoids vaccine and any acellular pertussis vaccine.
} 
2000. This occurred despite shortages of this vaccine during 2001-2004, which might have affected accessibility to PCV.

To collect vaccination data for age-eligible children, NIS uses a quarterly random-digit-dialed sample of telephone numbers for each survey area. NIS methodology, including the weighting of responses to represent the entire population of children aged 19-35 months, has been described previously (1). During 2005, the household survey response rate (2) was $65.1 \%$; health-care provider vaccination records were obtained for 17,563 children $(63.6 \%)$ for whom household interviews were completed.

National vaccination coverage estimates increased from 2004 to 2005 for PCV (Table 1), from $73.2 \%$ to $82.8 \%$ for $\geq 3$ doses and from $43.4 \%$ to $53.7 \%$ for $\geq 4$ doses. Coverage for $\geq 1$ dose of MMR vaccine decreased from $93.0 \%$ to $91.5 \%$. Coverage estimates for all other vaccines and vaccine series in 2005 were not significantly different (by $t$ test) from 2004 estimates.
As in previous years, estimated vaccination coverage levels varied substantially among states (Table 2). Estimated coverage with the 4:3:1:3:3:1 vaccine series ranged from 90.7\% (95\% confidence interval $[\mathrm{CI}]= \pm 3.8)$ in Massachusetts to $62.9 \%(\mathrm{CI}= \pm 8.1)$ in Vermont. Coverage also varied substantially among the 27 urban areas. The highest estimated coverage among the urban areas for the 4:3:1:3:3:1 series was $84.5 \%$ $(\mathrm{CI}= \pm 6.0)$ for Jefferson County, Alabama, and the lowest was $58.8 \%(\mathrm{CI}= \pm 7.9)$ for Clark County, Nevada.

In 2005, coverage estimates for the 4:3:1:3:3:1 vaccine series did not vary significantly by race/ethnicity** among children aged $19-35$ months, ranging from $79.5 \%(C I= \pm 4.2)$ for children of multiple races, $77.1 \%(\mathrm{CI}= \pm 6.0)$ for Asians, $76.3 \%(\mathrm{CI}= \pm 3.0)$ for blacks, $76.0 \%(\mathrm{CI}= \pm 1.4)$ for whites, and $75.6 \%(\mathrm{CI}= \pm 2.6)$ for Hispanics. During 2002-2004, coverage for the 4:3:1:3:3:1 vaccine series was lower among black compared with white children (Figure).

\footnotetext{
** For this report, persons identified as white, black, Asian, or multiple race are all non-Hispanic. Persons identified as Hispanic might be of any race.

TABLE 1. Estimated vaccination coverage among children aged 19-35 months, by selected vaccines and dosages National Immunization Survey, United States, 2001-2005

\begin{tabular}{|c|c|c|c|c|c|c|c|c|c|c|}
\hline \multirow[b]{2}{*}{ Vaccine/Dosage } & \multicolumn{2}{|r|}{ 2001* } & \multicolumn{2}{|c|}{$2002^{\dagger}$} & \multicolumn{2}{|c|}{$2003^{\S}$} & \multicolumn{2}{|c|}{$2004 \pi$} & \multicolumn{2}{|c|}{$2005^{\star \star}$} \\
\hline & $\%$ & $\left(95 \% \mathrm{Cl}^{++}\right)$ & $\%$ & $(95 \% \mathrm{Cl})$ & $\%$ & $(95 \% \mathrm{Cl})$ & $\%$ & $(95 \% \mathrm{Cl})$ & $\%$ & $(95 \% \mathrm{Cl})$ \\
\hline \multicolumn{11}{|l|}{ DTP/DT/DTaP§§ } \\
\hline$\geq 3$ doses & 94.3 & $( \pm 0.5)$ & 94.9 & $( \pm 0.6)$ & 96.0 & $( \pm 0.5)$ & 95.9 & $( \pm 0.5)$ & 96.1 & $( \pm 0.5)$ \\
\hline$\geq 4$ doses & 82.1 & $( \pm 0.8)$ & 81.6 & $( \pm 0.9)$ & 84.8 & $( \pm 0.8)$ & 85.5 & $( \pm 0.8)$ & 85.7 & $( \pm 0.9)$ \\
\hline Poliovirus & 89.4 & $( \pm 0.7)$ & 90.2 & $( \pm 0.7)$ & 91.6 & $( \pm 0.7)$ & 91.6 & $( \pm 0.7)$ & 91.7 & $( \pm 0.7)$ \\
\hline Hib ${ }^{\Uparrow} \geq 3$ doses & 93.0 & $( \pm 0.6)$ & 93.1 & $( \pm 0.6)$ & 93.9 & $( \pm 0.6)$ & 93.5 & $( \pm 0.6)$ & 93.9 & $( \pm 0.6)$ \\
\hline $\mathrm{MMR}^{\star \star \star} \geq 1$ dose & 91.4 & $( \pm 0.6)$ & 91.6 & $( \pm 0.7)$ & 93.0 & $( \pm 0.6)$ & 93.0 & $( \pm 0.6)$ & 91.5 & $( \pm 0.7)$ \\
\hline Hepatitis $B \geq 3$ doses & 88.9 & $( \pm 0.7)$ & 89.9 & $( \pm 0.7)$ & 92.4 & $( \pm 0.6)$ & 92.4 & $( \pm 0.6)$ & 92.9 & $( \pm 0.6)$ \\
\hline $\begin{array}{l}\text { Varicella } \geq 1 \text { dose } \\
\text { PCV }{ }^{\dagger \dagger}\end{array}$ & 76.3 & $( \pm 0.8)$ & 80.6 & $( \pm 0.9)$ & 84.8 & $( \pm 0.8)$ & 87.5 & $( \pm 0.7)$ & 87.9 & $( \pm 0.8)$ \\
\hline$\geq 3$ doses & - & - & 40.8 & $( \pm 1.1)$ & 68.1 & $( \pm 1.0)$ & 73.2 & $( \pm 1.0)$ & 82.8 & $( \pm 1.0)$ \\
\hline$\geq 4$ doses & - & - & - & - & 35.8 & $( \pm 1.0)$ & 43.4 & $( \pm 1.1)$ & 53.7 & $( \pm 1.3)$ \\
\hline \multicolumn{11}{|l|}{ Combined series } \\
\hline $4: 3: 1 \S \S \S$ & 78.6 & $( \pm 0.9)$ & 78.5 & $( \pm 1.0)$ & 82.2 & $( \pm 0.9)$ & 83.5 & $( \pm 0.9)$ & 83.1 & $( \pm 1.0)$ \\
\hline 4:3:1:3 3ๆๆๆ & 77.2 & $( \pm 0.9)$ & 77.5 & $( \pm 1.0)$ & 81.3 & $( \pm 0.9)$ & 82.5 & $( \pm 0.9)$ & 82.4 & $( \pm 1.0)$ \\
\hline $4: 3: 1: 3: 3^{\star \star \star \star}$ & 73.7 & $( \pm 0.9)$ & 74.8 & $( \pm 1.0)$ & 79.4 & $( \pm 0.9)$ & 80.9 & $( \pm 0.9)$ & 80.8 & $( \pm 1.0)$ \\
\hline 4:3:1:3:3:1†††† & 61.3 & $( \pm 1.0)$ & 65.5 & $( \pm 1.1)$ & 72.5 & $( \pm 1.0)$ & 76.0 & $( \pm 1.0)$ & 76.1 & $( \pm 1.1)$ \\
\hline
\end{tabular}

* Born during February 1998-May 2000.

$\dagger$ Born during February 1999-May 2001.

$\S$ Born during February 2000-May 2002.

१ी Born during February 2001-May 2003.

** Born during February 2002-July 2004.

t† Confidence interval.

$\S \S$ Diphtheria and tetanus toxoids and pertussis vaccines, diphtheria and tetanus toxoids vaccine, or diphtheria and tetanus toxoids vaccine and any acellular pertussis vaccine.

ๆी Haemophilus influenzae type $\mathrm{b}$ (Hib) vaccine.

*** Measles, mumps, and rubella vaccine.

t†† Pneumococcal conjugate vaccine.

$\S \S \S \geq 4$ doses of DTP/DT/DTaP, $\geq 3$ doses of poliovirus vaccine, and $\geq 1$ dose of any measles-containing vaccine.

ๆीๆ $4: 3: 1$ plus $\geq 3$ doses of Hib vaccine.

**** 4:3:1:3 plus $\geq 3$ doses of hepatitis $B$ vaccine.

t†t† $4: 3: 1: 3: 3$ plus $\geq 1$ dose of varicella vaccine. 
TABLE 2. Estimated vaccination coverage levels with $4: 3: 1,{ }^{*} 4: 3: 1: 3, \dagger 4: 3: 1: 3: 3, \S$ and $4: 3: 1: 3: 3: 1^{\text {Il }}$ series among children aged 19-35 months, by state and selected urban areas - National Immunization Survey, United States, 2005

\begin{tabular}{|c|c|c|c|c|c|c|c|c|}
\hline \multirow[b]{2}{*}{ State/Area } & \multicolumn{2}{|r|}{ 4:3:1 } & \multicolumn{2}{|c|}{ 4:3:1:3 } & \multicolumn{2}{|c|}{ 4:3:1:3:3 } & \multicolumn{2}{|c|}{ 4:3:1:3:3:1 } \\
\hline & $\%$ & $\left(95 \% \mathrm{Cl}^{* \star}\right)$ & $\%$ & $(95 \% \mathrm{Cl})$ & $\%$ & $(95 \% \mathrm{Cl})$ & $\%$ & $(95 \% \mathrm{Cl})$ \\
\hline United States & 83.1 & $( \pm 1.0)$ & 82.4 & $( \pm 1.0)$ & 80.8 & $( \pm 1.0)$ & 76.1 & $( \pm 1.1)$ \\
\hline Alabama & 86.0 & $( \pm 4.9)$ & 85.1 & $( \pm 5.0)$ & 83.3 & $( \pm 5.2)$ & 81.7 & $( \pm 5.5)$ \\
\hline Jefferson County & 89.3 & $( \pm 5.0)$ & 88.3 & $( \pm 5.3)$ & 85.5 & $( \pm 5.9)$ & 84.5 & $( \pm 6.0)$ \\
\hline Rest of state & 85.4 & $( \pm 5.8)$ & 84.6 & $( \pm 5.8)$ & 82.9 & $( \pm 6.1)$ & 81.2 & $( \pm 6.4)$ \\
\hline Alaska & 80.3 & $( \pm 6.3)$ & 77.7 & $( \pm 6.6)$ & 75.4 & $( \pm 6.8)$ & 68.1 & $( \pm 7.4)$ \\
\hline Arizona & 81.5 & $( \pm 4.6)$ & 81.0 & $( \pm 4.7)$ & 79.2 & $( \pm 4.9)$ & 74.9 & $( \pm 5.1)$ \\
\hline Maricopa County & 81.8 & $( \pm 6.2)$ & 81.1 & $( \pm 6.3)$ & 79.8 & $( \pm 6.5)$ & 76.4 & $( \pm 6.7)$ \\
\hline Rest of state & 80.8 & $( \pm 6.5)$ & 80.8 & $( \pm 6.5)$ & 78.2 & $( \pm 7.0)$ & 72.0 & $( \pm 7.5)$ \\
\hline Arkansas & 70.3 & $( \pm 9.0)$ & 69.3 & $( \pm 9.0)$ & 67.8 & $( \pm 9.0)$ & 64.2 & $( \pm 9.2)$ \\
\hline California & 80.5 & $( \pm 4.3)$ & 79.9 & $( \pm 4.3)$ & 77.9 & $( \pm 4.4)$ & 74.0 & $( \pm 4.8)$ \\
\hline Alameda County & 77.8 & $( \pm 8.2)$ & 76.7 & $( \pm 8.2)$ & 74.0 & $( \pm 8.5)$ & 71.1 & $( \pm 8.7)$ \\
\hline Los Angeles County & 82.9 & $( \pm 5.4)$ & 81.7 & $( \pm 5.6)$ & 79.0 & $( \pm 5.8)$ & 77.9 & $( \pm 5.9)$ \\
\hline San Bernardino County & 72.1 & $( \pm 7.2)$ & 69.3 & $( \pm 7.9)$ & 67.7 & $( \pm 7.9)$ & 62.8 & $( \pm 8.1)$ \\
\hline Rest of state & 80.3 & $( \pm 6.4)$ & 80.2 & $( \pm 6.4)$ & 78.5 & $( \pm 6.6)$ & 73.4 & $( \pm 7.1)$ \\
\hline Colorado & 85.1 & $( \pm 4.3)$ & 84.4 & $( \pm 4.3)$ & 83.4 & $( \pm 4.4)$ & 78.6 & $( \pm 5.1)$ \\
\hline Denver & 85.6 & $( \pm 6.4)$ & 84.9 & $( \pm 6.5)$ & 83.8 & $( \pm 6.6)$ & 78.8 & $( \pm 7.5)$ \\
\hline Rest of state & 84.7 & $( \pm 5.8)$ & 83.9 & $( \pm 5.8)$ & 83.2 & $( \pm 5.9)$ & 78.4 & $( \pm 6.9)$ \\
\hline Connecticut & 89.4 & $( \pm 4.9)$ & 89.4 & $( \pm 4.9)$ & 86.1 & $( \pm 5.4)$ & 81.5 & $( \pm 6.1)$ \\
\hline Delaware & 86.7 & $( \pm 6.3)$ & 86.7 & $( \pm 6.3)$ & 84.2 & $( \pm 6.6)$ & 81.6 & $( \pm 7.2)$ \\
\hline District of Columbia & 81.4 & $( \pm 5.6)$ & 78.0 & $( \pm 6.3)$ & 73.5 & $( \pm 6.6)$ & 72.1 & $( \pm 6.6)$ \\
\hline Florida & 81.5 & $( \pm 5.6)$ & 81.2 & $( \pm 5.6)$ & 79.3 & $( \pm 5.9)$ & 78.2 & $( \pm 6.0)$ \\
\hline Duval County & 79.4 & $( \pm 6.3)$ & 78.4 & $( \pm 6.3)$ & 78.0 & $( \pm 6.3)$ & 76.5 & $( \pm 6.4)$ \\
\hline Rest of state & 81.7 & $( \pm 6.0)$ & 81.4 & $( \pm 6.0)$ & 79.4 & $( \pm 6.3)$ & 78.3 & $( \pm 6.3)$ \\
\hline Georgia & 86.2 & $( \pm 4.2)$ & 85.9 & $( \pm 4.2)$ & 84.7 & $( \pm 4.3)$ & 82.4 & $( \pm 4.5)$ \\
\hline Fulton and DeKalb counties & 76.2 & $( \pm 8.7)$ & 76.0 & $( \pm 8.7)$ & 74.5 & $( \pm 8.8)$ & 71.8 & $( \pm 9.1)$ \\
\hline Rest of state & 88.4 & $( \pm 4.7)$ & 88.1 & $( \pm 4.7)$ & 87.0 & $( \pm 4.9)$ & 84.8 & $( \pm 5.1)$ \\
\hline Hawaii & 81.4 & $( \pm 6.4)$ & 81.1 & $( \pm 6.4)$ & 80.1 & $( \pm 6.5)$ & 77.5 & $( \pm 6.7)$ \\
\hline Idaho & 79.3 & $( \pm 5.6)$ & 79.3 & $( \pm 5.6)$ & 78.1 & $( \pm 5.8)$ & 68.4 & $( \pm 6.5)$ \\
\hline Illinois & 84.9 & $( \pm 5.6)$ & 84.8 & $( \pm 5.6)$ & 83.5 & $( \pm 5.7)$ & 76.7 & $( \pm 6.5)$ \\
\hline City of Chicago & 79.9 & $( \pm 6.0)$ & 79.4 & $( \pm 6.0)$ & 75.4 & $( \pm 6.4)$ & 69.7 & $( \pm 7.0)$ \\
\hline Rest of state & 86.7 & $( \pm 7.4)$ & 86.7 & $( \pm 7.4)$ & 86.4 & $( \pm 7.4)$ & 79.2 & $( \pm 8.5)$ \\
\hline Indiana & 78.9 & $( \pm 8.0)$ & 78.5 & $( \pm 8.0)$ & 78.1 & $( \pm 8.1)$ & 69.9 & $( \pm 8.6)$ \\
\hline lowa & 85.7 & $( \pm 5.6)$ & 84.9 & $( \pm 5.7)$ & 84.9 & $( \pm 5.7)$ & 75.9 & $( \pm 7.1)$ \\
\hline Kansas & 87.5 & $( \pm 4.6)$ & 86.2 & $( \pm 4.7)$ & 83.8 & $( \pm 5.0)$ & 72.0 & $( \pm 6.7)$ \\
\hline Kentucky & 84.8 & $( \pm 6.3)$ & 82.9 & $( \pm 6.8)$ & 79.7 & $( \pm 7.1)$ & 71.1 & $( \pm 8.1)$ \\
\hline Louisiana & 78.2 & $( \pm 4.3)$ & 77.1 & $( \pm 4.4)$ & 76.0 & $( \pm 4.4)$ & 74.1 & $( \pm 4.5)$ \\
\hline Maine & 88.8 & $( \pm 5.0)$ & 88.0 & $( \pm 5.1)$ & 83.3 & $( \pm 6.0)$ & 75.8 & $( \pm 6.7)$ \\
\hline Maryland & 84.3 & $( \pm 5.5)$ & 84.2 & $( \pm 5.5)$ & 82.3 & $( \pm 5.7)$ & 78.6 & $( \pm 6.1)$ \\
\hline City of Baltimore & 80.7 & $( \pm 6.9)$ & 80.1 & $( \pm 6.9)$ & 79.0 & $( \pm 7.0)$ & 76.5 & $( \pm 7.1)$ \\
\hline Rest of state & 84.8 & $( \pm 6.2)$ & 84.8 & $( \pm 6.2)$ & 82.7 & $( \pm 6.4)$ & 78.9 & $( \pm 6.9)$ \\
\hline Massachusetts & 95.6 & $( \pm 2.7)$ & 95.4 & $( \pm 2.7)$ & 93.5 & $( \pm 3.3)$ & 90.7 & $( \pm 3.8)$ \\
\hline Michigan & 84.5 & $( \pm 4.7)$ & 84.2 & $( \pm 4.7)$ & 82.7 & $( \pm 4.8)$ & 80.6 & $( \pm 5.0)$ \\
\hline City of Detroit & 75.8 & $( \pm 8.4)$ & 73.8 & $( \pm 8.7)$ & 73.1 & $( \pm 8.7)$ & 70.5 & $( \pm 8.9)$ \\
\hline Rest of state & 85.6 & $( \pm 5.2)$ & 85.4 & $( \pm 5.2)$ & 83.9 & $( \pm 5.3)$ & 81.8 & $( \pm 5.5)$ \\
\hline Minnesota & 88.4 & $( \pm 5.2)$ & 85.5 & $( \pm 5.7)$ & 85.2 & $( \pm 5.7)$ & 78.1 & $( \pm 6.4)$ \\
\hline Mississippi & 85.1 & $( \pm 5.1)$ & 84.4 & $( \pm 5.2)$ & 83.6 & $( \pm 5.3)$ & 79.1 & $( \pm 5.8)$ \\
\hline Missouri & 82.2 & $( \pm 4.3)$ & 80.9 & $( \pm 4.6)$ & 79.3 & $( \pm 4.7)$ & 73.1 & $( \pm 5.2)$ \\
\hline St. Louis County/City of St. Louis & 83.7 & $( \pm 5.7)$ & 83.7 & $( \pm 5.7)$ & 79.2 & $( \pm 6.3)$ & 73.6 & $( \pm 6.8)$ \\
\hline Rest of state & 81.7 & $( \pm 5.3)$ & 80.1 & $( \pm 5.7)$ & 79.4 & $( \pm 5.8)$ & 73.0 & $( \pm 6.3)$ \\
\hline Montana & 84.1 & $( \pm 5.4)$ & 83.1 & $( \pm 5.5)$ & 79.6 & $( \pm 6.1)$ & 65.4 & $( \pm 6.9)$ \\
\hline Nebraska & 91.0 & $( \pm 4.1)$ & 89.8 & $( \pm 4.4)$ & 89.1 & $( \pm 4.5)$ & 83.9 & $( \pm 5.2)$ \\
\hline Nevada & 71.2 & $( \pm 5.9)$ & 71.1 & $( \pm 5.9)$ & 66.7 & $( \pm 6.0)$ & 63.2 & $( \pm 6.1)$ \\
\hline Clark County & 68.5 & $( \pm 7.6)$ & 68.5 & $( \pm 7.6)$ & 63.1 & $( \pm 7.7)$ & 58.8 & $( \pm 7.9)$ \\
\hline Rest of state & 78.9 & $( \pm 7.4)$ & 78.4 & $( \pm 7.4)$ & 76.9 & $( \pm 7.5)$ & 75.8 & $( \pm 7.5)$ \\
\hline New Hampshire & 85.0 & $( \pm 5.1)$ & 85.0 & $( \pm 5.1)$ & 82.8 & $( \pm 5.7)$ & 77.1 & $( \pm 6.1)$ \\
\hline
\end{tabular}

$* \geq 4$ doses of diphtheria and tetanus toxoids and pertussis vaccines, diphtheria and tetanus toxoids vaccine, or diphtheria and tetanus toxoids vaccine and any acellular pertussis vaccine (DTP/DT/DTaP); $\geq 3$ doses of poliovirus vaccine; and $\geq 1$ dose of any measles-containing vaccine.

$\dagger$ 4:3:1 plus $\geq 3$ doses of Haemophilus influenzae type $b$ vaccine.

$\S 4: 3: 1: 3$ plus $\geq 3$ doses of hepatitis $B$ vaccine.

If $4: 3: 1: 3: 3$ plus $\geq 1$ dose of varicella vaccine.

** Confidence interval. 
TABLE 2. (Continued) Estimated vaccination coverage levels with $4: 3: 1,{ }^{\star} 4: 3: 1: 3,{ }^{\dagger} 4: 3: 1: 3: 3, \S$ and $4: 3: 1: 3: 3: 1$ ाl series among children aged 19-35 months, by state and selected urban areas — National Immunization Survey, United States, 2005

\begin{tabular}{|c|c|c|c|c|c|c|c|c|}
\hline \multirow[b]{2}{*}{ State/Area } & \multicolumn{2}{|r|}{$4: 3: 1$} & \multicolumn{2}{|c|}{$4: 3: 1: 3$} & \multicolumn{2}{|c|}{$4: 3: 1: 3: 3$} & \multicolumn{2}{|c|}{$4: 3: 1: 3: 3: 1$} \\
\hline & $\%$ & $\left(95 \% \mathrm{Cl}^{\star \star}\right)$ & $\%$ & $(95 \% \mathrm{Cl})$ & $\%$ & $(95 \% \mathrm{Cl})$ & $\%$ & $(95 \% \mathrm{Cl})$ \\
\hline New Jersey & 79.3 & $( \pm 5.8)$ & 78.5 & $( \pm 5.9)$ & 78.2 & $( \pm 5.9)$ & 72.4 & $( \pm 6.4)$ \\
\hline City of Newark & 78.2 & $( \pm 6.2)$ & 77.3 & $( \pm 6.3)$ & 75.0 & $( \pm 6.6)$ & 67.4 & $( \pm 7.1)$ \\
\hline Rest of state & 79.4 & $( \pm 6.1)$ & 78.6 & $( \pm 6.1)$ & 78.4 & $( \pm 6.1)$ & 72.6 & $( \pm 6.7)$ \\
\hline New Mexico & 81.5 & $( \pm 6.3)$ & 79.6 & $( \pm 6.5)$ & 78.4 & $( \pm 6.7)$ & 74.6 & $( \pm 7.0)$ \\
\hline New York & 85.0 & $( \pm 4.0)$ & 83.7 & $( \pm 4.1)$ & 81.6 & $( \pm 4.3)$ & 74.4 & $( \pm 4.7)$ \\
\hline City of New York & 83.2 & $( \pm 6.4)$ & 81.0 & $( \pm 6.7)$ & 78.1 & $( \pm 7.0)$ & 70.5 & $( \pm 7.4)$ \\
\hline Rest of state & 86.7 & $( \pm 4.8)$ & 86.2 & $( \pm 4.9)$ & 84.8 & $( \pm 5.0)$ & 78.1 & $( \pm 5.9)$ \\
\hline North Carolina & 89.1 & $( \pm 4.8)$ & 89.1 & $( \pm 4.8)$ & 85.2 & $( \pm 5.4)$ & 81.6 & $( \pm 5.8)$ \\
\hline North Dakota & 86.6 & $( \pm 4.5)$ & 86.3 & $( \pm 4.5)$ & 85.0 & $( \pm 4.7)$ & 78.7 & $( \pm 5.4)$ \\
\hline Ohio & 85.4 & $( \pm 4.4)$ & 85.0 & $( \pm 4.4)$ & 84.1 & $( \pm 4.5)$ & 77.7 & $( \pm 5.1)$ \\
\hline Cuyahoga County & 88.0 & $( \pm 4.6)$ & 86.6 & $( \pm 4.9)$ & 84.8 & $( \pm 5.3)$ & 77.4 & $( \pm 6.3)$ \\
\hline Franklin County & 87.0 & $( \pm 6.1)$ & 86.7 & $( \pm 6.1)$ & 85.9 & $( \pm 6.2)$ & 80.5 & $( \pm 7.1)$ \\
\hline Rest of state & 84.8 & $( \pm 5.6)$ & 84.5 & $( \pm 5.6)$ & 83.8 & $( \pm 5.7)$ & 77.3 & $( \pm 6.4)$ \\
\hline Oklahoma & 77.3 & $( \pm 5.9)$ & 76.9 & $( \pm 5.9)$ & 75.7 & $( \pm 6.0)$ & 72.3 & $( \pm 6.2)$ \\
\hline Oregon & 76.1 & $( \pm 6.7)$ & 75.3 & $( \pm 6.7)$ & 72.9 & $( \pm 7.1)$ & 65.3 & $( \pm 7.4)$ \\
\hline Pennsylvania & 84.5 & $( \pm 5.2)$ & 83.4 & $( \pm 5.2)$ & 83.2 & $( \pm 5.2)$ & 77.3 & $( \pm 5.8)$ \\
\hline Philadelphia County & 85.0 & $( \pm 5.6)$ & 79.9 & $( \pm 6.5)$ & 78.7 & $( \pm 6.5)$ & 77.0 & $( \pm 6.6)$ \\
\hline Rest of state & 84.4 & $( \pm 6.0)$ & 84.1 & $( \pm 6.1)$ & 84.1 & $( \pm 6.1)$ & 77.3 & $( \pm 6.7)$ \\
\hline Rhode Island & 85.7 & $( \pm 4.6)$ & 84.3 & $( \pm 4.8)$ & 83.1 & $( \pm 4.9)$ & 80.1 & $( \pm 5.3)$ \\
\hline South Carolina & 79.2 & $( \pm 6.6)$ & 78.5 & $( \pm 6.6)$ & 78.5 & $( \pm 6.6)$ & 75.6 & $( \pm 6.8)$ \\
\hline South Dakota & 88.4 & $( \pm 4.5)$ & 88.1 & $( \pm 4.5)$ & 86.9 & $( \pm 4.7)$ & 79.5 & $( \pm 5.8)$ \\
\hline Tennessee & 84.4 & $( \pm 4.0)$ & 83.8 & $( \pm 4.1)$ & 82.9 & $( \pm 4.2)$ & 80.0 & $( \pm 4.5)$ \\
\hline Davidson County & 86.6 & $( \pm 6.1)$ & 86.6 & $( \pm 6.1)$ & 86.6 & $( \pm 6.1)$ & 81.3 & $( \pm 6.9)$ \\
\hline Shelby County & 76.4 & $( \pm 7.6)$ & 76.2 & $( \pm 7.6)$ & 75.8 & $( \pm 7.6)$ & 74.1 & $( \pm 7.6)$ \\
\hline Rest of state & 86.1 & $( \pm 5.2)$ & 85.3 & $( \pm 5.4)$ & 84.1 & $( \pm 5.6)$ & 81.4 & $( \pm 6.0)$ \\
\hline Texas & 81.5 & $( \pm 3.7)$ & 80.8 & $( \pm 3.7)$ & 78.4 & $( \pm 3.9)$ & 76.8 & $( \pm 4.0)$ \\
\hline Bexar County & 78.7 & $( \pm 7.2)$ & 77.4 & $( \pm 7.3)$ & 74.6 & $( \pm 7.5)$ & 71.3 & $( \pm 7.7)$ \\
\hline City of Houston & 80.6 & $( \pm 5.9)$ & 80.3 & $( \pm 5.9)$ & 78.1 & $( \pm 6.1)$ & 76.6 & $( \pm 6.1)$ \\
\hline Dallas County & 78.7 & $( \pm 7.2)$ & 77.3 & $( \pm 7.4)$ & 74.2 & $( \pm 7.8)$ & 72.8 & $( \pm 7.9)$ \\
\hline El Paso County & 76.2 & $( \pm 6.0)$ & 76.2 & $( \pm 6.0)$ & 71.1 & $( \pm 6.4)$ & 69.2 & $( \pm 6.4)$ \\
\hline Rest of state & 82.7 & $( \pm 5.2)$ & 82.1 & $( \pm 5.3)$ & 80.0 & $( \pm 5.7)$ & 78.5 & $( \pm 5.8)$ \\
\hline Utah & 75.7 & $( \pm 8.4)$ & 75.7 & $( \pm 8.4)$ & 74.1 & $( \pm 8.5)$ & 68.1 & $( \pm 8.8)$ \\
\hline Vermont & 83.4 & $( \pm 6.2)$ & 83.4 & $( \pm 6.2)$ & 81.5 & $( \pm 6.4)$ & 62.9 & $( \pm 8.1)$ \\
\hline Virginia & 86.0 & $( \pm 5.8)$ & 85.8 & $( \pm 5.8)$ & 85.8 & $( \pm 5.8)$ & 81.7 & $( \pm 6.1)$ \\
\hline Washington & 81.2 & $( \pm 5.0)$ & 81.2 & $( \pm 5.0)$ & 77.8 & $( \pm 5.2)$ & 66.3 & $( \pm 5.9)$ \\
\hline King County & 84.0 & $( \pm 7.2)$ & 84.0 & $( \pm 7.2)$ & 76.8 & $( \pm 7.8)$ & 68.7 & $( \pm 8.3)$ \\
\hline Rest of state & 80.1 & $( \pm 6.4)$ & 80.1 & $( \pm 6.4)$ & 78.2 & $( \pm 6.5)$ & 65.4 & $( \pm 7.5)$ \\
\hline West Virginia & 78.8 & $( \pm 6.6)$ & 78.2 & $( \pm 6.7)$ & 74.9 & $( \pm 7.1)$ & 67.5 & $( \pm 7.8)$ \\
\hline Wisconsin & 85.6 & $( \pm 4.4)$ & 85.0 & $( \pm 4.5)$ & 82.2 & $\pm 5.1)$ & 77.1 & $\pm 5.5)$ \\
\hline Milwaukee County & 80.6 & $( \pm 8.6)$ & 79.7 & $( \pm 8.6)$ & 79.1 & $( \pm 8.6)$ & 73.6 & $( \pm 9.0)$ \\
\hline Rest of state & 86.9 & $( \pm 5.1)$ & 86.4 & $( \pm 5.2)$ & 83.0 & $( \pm 6.0)$ & 78.1 & $( \pm 6.6)$ \\
\hline Wyoming & 80.7 & $( \pm 5.9)$ & 80.5 & $( \pm 5.9)$ & 78.6 & $( \pm 6.1)$ & 66.9 & $( \pm 7.2)$ \\
\hline
\end{tabular}

In 2005, estimated coverage varied significantly by race/ ethnicity for three individual vaccines: DTP/DT/DTaP; varicella vaccine; and PCV. For $\geq 4$ doses of DTP/DT/DTaP, coverage was significantly lower for black $(84.0 \%[\mathrm{CI}= \pm 2.5])$ and Hispanic $(83.6 \%[\mathrm{CI}= \pm 2.3])$ children compared with white children $(87.1 \%[\mathrm{CI}= \pm 1.1])$. For $\geq 1$ dose of varicella vaccine, coverage was significantly higher for black ([90.6\% $[\mathrm{CI}= \pm 1.8])$ and Hispanic $(89.2 \%[\mathrm{CI}= \pm 1.7])$ children compared with white children $(86.1 \%[\mathrm{CI}= \pm 1.2])$. For $\geq 3$ doses of PCV, coverage was significantly lower for black $(79.6 \%$ $[\mathrm{CI}= \pm 3.1])$ compared with white children $(83.2 \%$ $[\mathrm{CI}= \pm 1.3])$. For $\geq 4$ doses of PCV, coverage was significantly lower among black $(46.2 \%[\mathrm{CI}= \pm 3.8])$ and Hispanic children $(50.5 \%[\mathrm{CI}= \pm 2.8])$ compared with white children $(57.3 \%[\mathrm{CI}= \pm 1.6])$.

Reported by: $N$ Darling, MPH, JA Singleton, MS, J Santoli, MD, Immunization Svc Div, National Center for Immunization and Respiratory Diseases (proposed), CDC.

Editorial Note: The findings in this report indicate that among U.S. children aged 19-35 months, coverage with the recommended vaccines in 2005 remained at or near all-time-high levels, with substantial increases in PCV coverage. The 2005 NIS survey cohort included children born during February 2002-July 2004; all of these children might have been affected by the shortages of PCV during FebruarySeptember 2004, when recommendations to defer the 4th dose 
FIGURE. Estimated vaccination coverage with the 4:3:1:3:3:1 vaccine series* among children aged 19-35 months, by race/ethnicity and year - National Immunization Survey, United States, 2002-2005

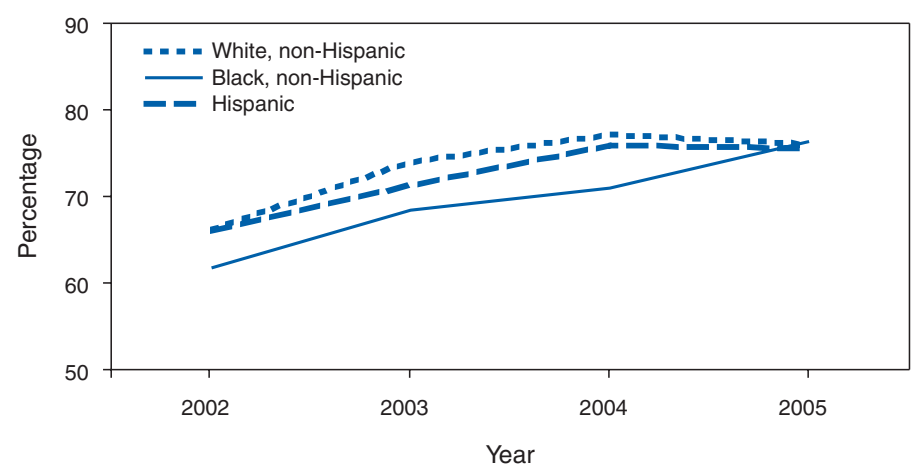

* $>4$ doses of diphtheria and tetanus toxoids and pertussis vaccines, diphtheria and tetanus toxoids vaccine, or diphtheria and tetanus toxoids vaccine and any acellular pertussis vaccine (DTP/DT/DTaP); $\geq 3$ doses of poliovirus vaccine; $\geq 1$ dose of measles, mumps, and rubella vaccine; $\geq 3$ doses of Haemophilus influenzae type $b$ vaccine; $\geq 3$ doses of hepatitis $B$ vaccine; and $\geq 1$ dose of varicella vaccine.

or the 3rd and 4th doses were in effect $(3,4)$. Despite these shortages, coverage with the full series ( $\geq 4$ doses) exceeded $50 \%$ and coverage with $\geq 3$ doses of PCV exceeded $80 \%$ in this survey cohort. Surveillance data from 1998-2003 have indicated substantial reductions in the incidence of vaccinetype and overall invasive pneumococcal disease in children and adults, attributable to routine use of PCV in young children (5). Although 4 doses of PCV are recommended for maximum protection against invasive pneumococcal disease (G), the vaccine might provide protection with 3 doses through decreased transmission of pneumococci organisms among children (5). Continued measures to increase PCV coverage with all recommended doses are needed, particularly for black and Hispanic children.

The 2005 data reflect the first year that the 4:3:1:3:3:1 vaccine series was used to evaluate progress toward one of the Healthy People 2010 objectives, which aims to achieve $>80 \%$ coverage with the 4:3:1:3:3:1 series among children aged 1935 months (objective-14.24a) (7). Although the $80 \%$ target was met in 2004 for 4:3:1:3:3 coverage (excludes varicella vaccine), vaccination coverage for the 4:3:1:3:3:1 series in 2005 remained stable at $76.1 \%$, compared with $76.0 \%$ in 2004 .

In the 2005 NIS survey cohort, coverage levels for the 4:3:1:3:3:1 series were similar among racial/ethnic groups, which represents an improvement over recent years; an evaluation of NIS data from 1996 to 2002 revealed increasing or stable racial/ethnic disparities in the $4: 3: 1: 3: 3$ vaccination series coverage levels for black and Hispanic children compared with white children (8). Continued monitoring is needed to determine whether the narrowing gaps in coverage among racial/ethnic groups persist. Monitoring the disparities in administration of DTP/DT/DTaP, varicella vaccine, and PCV will be important, particularly for $\mathrm{PCV}$, which protects against a disease with higher incidence among black children.

The only statistically significant decrease in coverage from 2004 to 2005 was for $\geq 1$ dose of MMR. However, this decrease was modest, and national MMR coverage has remained consistent, ranging from $91 \%$ to $93 \%$ since 2001 . The recent outbreak of mumps in the United States underscores the importance of timely administration of the first dose of MMR and the need for administration of the second dose at ages $4-6$ years. Coverage in this age group is assessed by state health departments in their evaluation of school entry immunization requirements (9).

The findings in this report are subject to at least three limitations. First, NIS is a telephone survey; although NIS results are weighted to make them representative of all children aged 19-35 months (e.g., accounting for nonresponse and households without telephones), some bias might remain after these statistical adjustments. Second, NIS uses provider-verified vaccination histories and assumes that coverage among children whose providers did not respond is similar to coverage among children whose providers did respond; thus, incomplete reporting might have resulted in underestimates of coverage. Finally, although national estimates are precise (1), annual estimates and trends for states and urban areas should be interpreted with caution because of wider confidence intervals.

High vaccination coverage levels should be achieved and maintained to reduce the impact of vaccine-preventable diseases. Routine childhood vaccination with the vaccines included in the $4: 3: 1: 3: 3: 1$ series results in net societal savings of an estimated $\$ 43$ billion per annual birth cohort (10). Coverage varied substantially by state, ranging from $63 \%$ to 91\% for the 4:3:1:3:3:1 vaccine series, and by race/ethnicity for DT/DTP/DTaP, varicella vaccine, and PCV, indicating that further progress in increasing coverage is needed in many areas. NIS data will continue to be used to monitor vaccination status among preschool-aged children for recommended vaccines. Future NIS data will be used to assess routine rotavirus and hepatitis A vaccination of preschool-aged children, recommended in 2006, and use of a measles-mumpsrubella-varicella (MMRV) vaccine licensed in 2005.

In addition to the recently recommended vaccines for preschool-aged children, three vaccines have been recommended recently for children aged 11-12 years: meningococcal conjugate vaccine (MCV4); tetanus, diphtheria, and acellular pertussis (Tdap) vaccine instead of tetanus and diphtheria toxoids vaccine (Td); and human papillomavirus vaccine (HPV). The NIS will be expanded during the fourth quarter of 2006 to assess coverage for recommended vaccines received among 
children aged 13-17 years. This enhancement underscores the importance of survey systems such as the NIS in monitoring new vaccine implementation, which can provide valuable information for improving overall vaccination coverage.

\section{References}

1. Smith PJ, Hoaglin DC, Battaglia MP, Khare M, Barker LE. Statistical methodology of the National Immunization Survey, 1994-2002. National Center for Health Statistics. Vital Health Stat 2005;2(138).

2. The American Association for Public Opinion Research. Standard definitions: final dispositions of case codes and outcome rates for surveys. 4th ed. Lenexa, Kansas: American Association for Public Opinion Research; 2006. Available at http://www.aapor.org/pdfs/ standarddefs_4.pdf.

3. CDC. Pneumococcal conjugate vaccine shortage resolved. MMWR 2003;52:446-7.

4. CDC. Pneumococcal conjugate vaccine shortage resolved. MMWR 2004;53:851-2.

5. CDC. Direct and indirect effects of routine vaccination of children with 7-valent pneumococcal conjugate vaccine on incidence of invasive pneumococcal diseases-United States, 1998-2003. MMWR 2005;54:893-7.

6. CDC. Preventing pneumococcal disease among infants and young children: recommendations of the Advisory Committee on Immunization Practices (ACIP). MMWR 2000;49(No. RR-9).

7. US Department of Health and Human Services. Healthy people 2010 (conference ed, in 2 vols). Washington, DC: US Department of Health and Human Services; 2000. Available at http://www.health.gov/ healthypeople.

8. Barker LE, Chu SY, Smith PJ. Disparities in immunizations [Letter]. Am J Public Health 2004;94:906.

9. CDC. Updated recommendations of the Advisory Committee on Immunization Practices (ACIP) for the control and prevention of mumps. MMWR 2006;55:629-30.

10. Zhou F, Santoli J, Messonier ML, et al. Economic evaluation of the 7vaccine routine childhood immunization schedule in the United States, 2001. Arch Pediatr Adolesc Med 2005;159:1136-44.

\section{Public Health Response to Varicella Outbreaks - United States, 2003-2004}

Since introduction of varicella vaccine in 1995, incidence of varicella has decreased as vaccination coverage has increased $(1,2)$. Nevertheless, varicella outbreaks continue to occur, even among populations with high vaccination coverage (3-5). Although varicella typically is mild, the outbreaks can last for several months and be challenging and costly for health departments to control. In 2005, CDC conducted a national survey to determine the distribution and extent of reported varicella outbreaks during 2003-2004 and the public health response. This report summarizes the results of that survey, which indicated that varicella outbreaks are still common and that health jurisdictions are responding to these outbreaks, although they have varying definitions and guidelines for varicella-outbreak management.
During April-May 2005, a voluntary, Internet-based survey was sent by e-mail to 59 CDC immunization program grantees: 50 states and the District of Columbia (DC), five cities (Chicago, Illinois; Houston, Texas; New York City, New York; Philadelphia, Pennsylvania; and San Antonio, Texas), and three U.S. territories (Guam, Puerto Rico, and the U.S. Virgin Islands). These health jurisdictions were asked questions about varicella outbreaks identified during 2003-2004, including local definitions of outbreaks, existence of outbreak management guidelines, and outbreak response strategies used.

Fifty-five $(93 \%)$ of 59 jurisdictions responded to the survey; Alaska, New Mexico, Utah, and the U.S. Virgin Islands did not participate. In 2003, 43 (78\%) of the 55 jurisdictions were notified of at least one varicella outbreak, and $10(18 \%)$ were notified of six or more; in 2004, 45 (82\%) were notified of at least one varicella outbreak, and 13 (24\%) were notified of six or more. Additional information regarding 190 outbreaks that occurred in 2004 was obtained from 24 jurisdictions. Of the outbreaks reported to these jurisdictions, $67 \%$ occurred in elementary schools, and $43 \%$ included patients with a median age of $5-9$ years; $64 \%$ had $\leq 10$ cases, $26 \%$ had $11-40$ cases, and $10 \%$ had $41-50$ cases.

When asked whether their health jurisdiction had a formal program definition for varicella outbreaks, approximately $70 \%$ of the 55 responding jurisdictions indicated that they did, and the definitions varied (Figure 1). Forty-four percent of jurisdictions reported that they had guidelines for managing varicella outbreaks. When asked whether their health jurisdiction responds to an outbreak if notified, ${ }^{\dagger} 47$ of the 55 jurisdictions reported that they did. Thirty (55\%) of these jurisdictions stated that their outbreak response involved both local and state health departments, 10 (18\%) said that it involved the state health department only, and seven (13\%) said that it involved the local health department only; eight jurisdictions did not respond. Among the 47 jurisdictions that respond to outbreaks, the most commonly reported criteria used to determine whether to respond were the population affected (57\%), the outbreak setting (68\%), and the size of the outbreak (68\%); the age of patients was a less frequently used criterion (40\%) (Figure 2). Approximately $35 \%$ of jurisdictions identified at least one other criterion.

\footnotetext{
* Health jurisdictions that receive federal grants to assist with vaccination programs.

$\dagger$ Jurisdictions were asked, "Does your health department at times respond to varicella outbreaks? (Note: By 'respond,' at minimum, recording reported outbreaks in a log book including total number of cases, with or without additional variables.)" Possible replies were "Yes, state and local health departments respond; yes, only state health department responds; yes, only local health department responds; or no, there is no response."
} 
FIGURE 1. Percentage of jurisdictions, ${ }^{*}$ by definition used for varicella outbreak - United States, 2003-2004

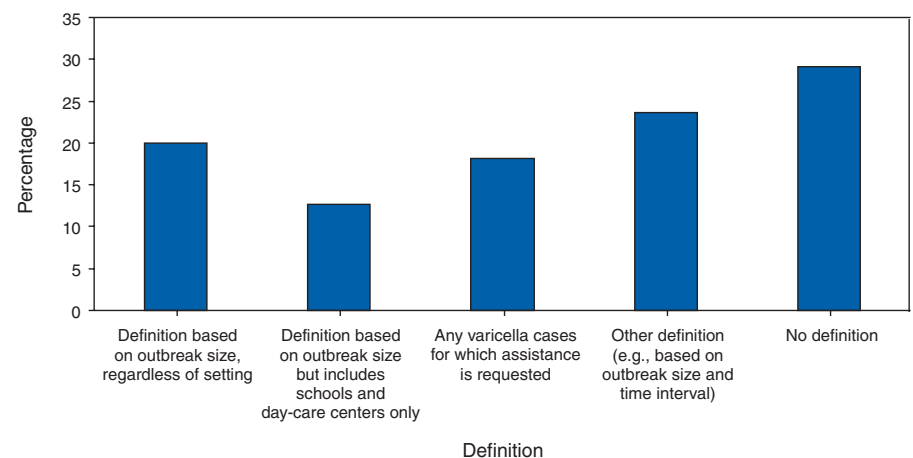

* Jurisdictions $(\mathrm{N}=55)$ that responded to the survey. States: Alabama, Arizona, Arkansas, California, Colorado, Connecticut, Delaware, Florida, Georgia, Hawaii, Idaho, Illinois, Indiana, lowa, Kansas, Kentucky, Louisiana, Maine, Maryland, Massachusetts, Michigan, Minnesota, Mississippi, Missouri, Montana, Nebraska, Nevada, New Hampshire, New Jersey, New York, North Carolina, North Dakota, Ohio, Oklahoma, Oregon, Pennsylvania, Rhode Island, South Carolina, South Dakota, Tennessee, Texas, Vermont, Virginia, Washington, West Virginia, Wisconsin, and Wyoming. Cities and other areas: Chicago, Illinois; Houston, Texas; New York City, New York; Philadelphia, Pennsylvania; San Antonio, Texas; District of Columbia; Guam; and Puerto Rico. California and District of Columbia listed two outbreak definitions.

Among the jurisdictions that respond to outbreaks, frequently used response strategies included verifying vaccination history, excluding patients from the outbreak setting, and documenting relevant outbreak information, such as age of patients. Vaccinating or excluding susceptible contacts from the outbreak setting and conducting laboratory testing to assess susceptibility were not frequently used strategies (Table). Reported by: J Leung, MPH, A Lopez, MHS, F Averhoff, MD, R Harpaz, MD, D Guris, MD, JF Seward, MBBS, MPH, Div of Viral Diseases, National Center for Immunization and Respiratory Diseases (proposed), $C D C$.

Editorial Note: The results of this survey indicate that varicella outbreaks are still common despite increasing vaccination coverage. During 2004, 45 jurisdictions were notified of varicella outbreaks, and 18 reported them to CDC. More comprehensive information about occurring outbreaks would be useful for monitoring the effects of the vaccination program and evaluating vaccination policies.

Approximately two thirds of jurisdictions have formal, but varying, definitions for a varicella outbreak, and almost half of jurisdictions have existing varicella-outbreak management guidelines. Creating a standard definition for varicella outbreaks would be useful for monitoring the outbreak trends among jurisdictions, and establishing outbreak management guidelines might facilitate a more uniform response, especially at the local level, and ensure that critical procedures are not overlooked. CDC is working with state and local health departments to develop a standard definition and national
FIGURE 2. Percentage of jurisdictions* that respond to varicella outbreaks, by criteria for responding - United States, 2003-2004

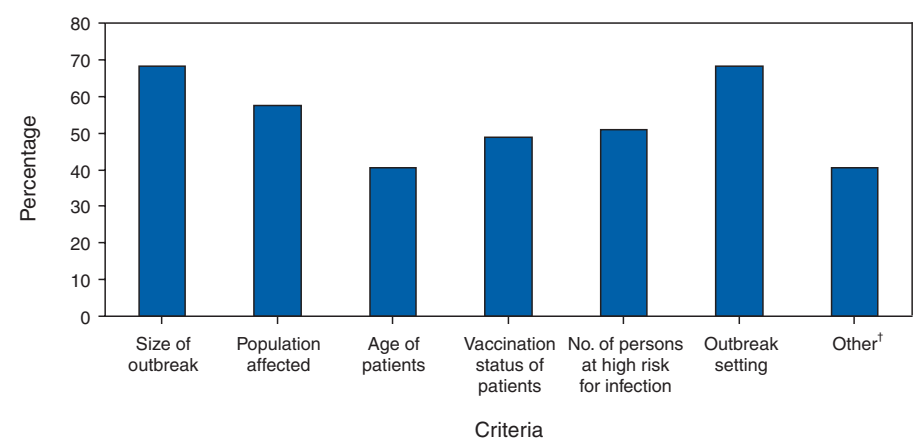

* Jurisdictions $(n=47)$ that respond to varicella outbreaks if notified. States: Arizona, Arkansas, California, Colorado, Connecticut, Delaware, Florida, Georgia, Hawaii, Idaho, Illinois, Indiana, lowa, Kansas, Louisiana, Maine, Maryland, Massachusetts, Michigan, Minnesota, Missouri, Montana, Nebraska, Nevada, New Hampshire, New Jersey, New York, North Carolina, North Dakota, Oklahoma, Oregon, Pennsylvania, Rhode Island, South Carolina, South Dakota, Tennessee, Texas, Vermont, Virginia, West Virginia, and Wisconsin. Cities and other areas: Chicago, Illinois; Houston, Texas; New York City, New York; Philadelphia, Pennsylvania; District of Columbia; and Puerto Rico.

$\dagger$ Includes local interest; for training purposes; whether a request was received from particular setting, such as a school or local agency; whether pregnant contacts are involved; whether a death is involved; whether the outbreak involves rash illness; or whether breakthrough cases are involved. Some jurisdictions respond to all outbreaks.

guidelines for management of varicella outbreaks to be published in a future $M M W R$.

Forty-seven of the jurisdictions indicate that they respond to varicella outbreaks if notified, although response strategies vary. A standard response for all varicella outbreaks should include a letter from the local health department or outbreak setting to inform the affected population of the outbreak. In addition, persons without evidence of immunity ${ }^{\S}(\sigma)$ should be vaccinated either by their primary-care physician or at a vaccination clinic in outbreak settings. Vaccination of susceptible populations who might have been exposed during an outbreak or who have been exposed to infection is important to prevent illness and decrease disease severity.

In June 2005, the Advisory Committee on Immunization Practices (ACIP) provisionally recommended a second dose of varicella vaccine in outbreak settings for persons who have had only 1 dose of varicella vaccine and no disease history (provided that an appropriate interval has elapsed since the first dose) (6). On the basis of a 10-year follow-up prelicensure study of the vaccine, a 2-dose vaccination regimen has been determined more effective than a 1-dose regimen ( 7 ).

In a 2006 position statement, the Council of State and Territorial Epidemiologists (CSTE) supported a routine 2-dose

\footnotetext{
${ }^{\S}$ Definition is available at http://www.cdc.gov/nip/vaccine/varicella/ varicella_acip_recs_prov_june_2006.pdf.
} 
TABLE. Percentage of jurisdictions* that respond to varicella outbreaks, by strategy used — United States, 2003-2004

\begin{tabular}{|c|c|c|c|c|c|c|}
\hline \multirow[b]{2}{*}{ Strategy } & \multicolumn{2}{|c|}{ Always } & \multicolumn{2}{|c|}{ Sometimes } & \multicolumn{2}{|c|}{ Never } \\
\hline & No. & $(\%)$ & No. & $(\%)$ & No. & (\%) \\
\hline Sending letters to parents during school or day-care center outbreaks & 21 & $(45)$ & 19 & $(40)$ & 7 & $(15)$ \\
\hline Notifying health-care providers and affected population & & & & & & \\
\hline of outbreak & 7 & $(15)$ & 30 & $(64)$ & 10 & $(21)$ \\
\hline Vaccinating susceptible contacts & 13 & (28) & 22 & (47) & 12 & (26) \\
\hline Excluding patients from outbreak setting & 31 & $(66)$ & 6 & $(13)$ & 10 & $(21)$ \\
\hline Excluding unvaccinated contacts from outbreak setting & 7 & $(15)$ & 13 & (28) & 27 & $(57)$ \\
\hline Screening for varicella susceptibility (e.g., obtaining disease and & & & & & & \\
\hline vaccination history information) among uninfected persons & 14 & (30) & 20 & (43) & 13 & $(28)$ \\
\hline Verifying vaccination information for patients & 19 & (40) & 19 & (40) & 9 & (19) \\
\hline Verifying vaccination information for uninfected persons & 10 & $(21)$ & 18 & (38) & 19 & $(40)$ \\
\hline $\begin{array}{l}\text { Conducting laboratory testing to assess susceptibility among } \\
\text { uninfected persons }\end{array}$ & 0 & (0) & 21 & $(45)$ & 26 & $(55)$ \\
\hline Conducting laboratory testing to confirm diagnosis & 4 & (9) & 25 & (53) & 18 & (38) \\
\hline Investigating outbreak & & & & & & \\
\hline Recording information provided by reporters & 36 & (77) & 9 & (19) & 2 & (4) \\
\hline Performing varicella case-finding activities & 24 & (51) & 15 & (32) & 8 & (17) \\
\hline Gathering age of patients & 33 & (70) & 11 & (23) & 3 & (6) \\
\hline Collecting information on clinical symptoms of patients & 26 & (55) & 15 & (32) & 6 & (13) \\
\hline
\end{tabular}

*Jurisdictions $(n=47)$ that respond to outbreaks if notified. States: Arizona, Arkansas, California, Colorado, Connecticut, Delaware, Florida, Georgia, Hawaii, Idaho, Illinois, Indiana, lowa, Kansas, Louisiana, Maine, Maryland, Massachusetts, Michigan, Minnesota, Missouri, Montana, Nebraska, Nevada, New Hampshire, New Jersey, New York, North Carolina, North Dakota, Oklahoma, Oregon, Pennsylvania, Rhode Island, South Carolina, South Dakota, Tennessee, Texas, Vermont, Virginia, West Virginia, and Wisconsin. Cities and other areas: Chicago, Illinois; Houston, Texas; New York City, New York; Philadelphia, Pennsylvania; District of Columbia; and Puerto Rico.

varicella vaccination policy to improve varicella control and outbreak prevention. In June 2006, ACIP approved a routine 2-dose varicella vaccination policy for children (first dose at 12-15 months, second dose at 4-6 years) and catch-up vaccinations for children, adolescents, and adults who had previously received only 1 dose. Establishing a routine 2-dose vaccination regimen might make the 2 -dose outbreak response for susceptible populations more feasible to implement.

In 2002, CSTE also recommended that states should establish individual case-based varicella surveillance by 2005 (8). Case-based reporting should improve detection of varicella outbreaks, the quality of the data reported from outbreaks, and the evaluation of outbreak-control measures.

The findings in this report are subject to at least two limitations. First, the data are taken from reports from jurisdictions and are subject to reporting biases such as recall bias. Second, varying outbreak definitions and reporting methods might have led to underestimation of the extent and distribution of varicella outbreaks.

As national outbreak guidelines are being created, jurisdictions are encouraged to contact CDC for assistance with investigating and responding to varicella outbreaks. Guidance on outbreak management and investigation also can be found in CDC's Manual for the Surveillance of Vaccine-Preventable Diseases (9).

\section{Acknowledgments}

The data in this report are based, in part, on information supplied by health departments of states, cities, and U.S. territories.
The survey was conducted with assistance from the Immunization Svcs Div, National Center for Immunization and Respiratory Diseases (proposed), CDC

\section{References}

1. CDC. National, state, and urban area vaccination coverage among children aged 19-35 months_-United States, 2004. MMWR 2005;54:71721. Available at http://www.cdc.gov/mmwr/preview/mmwrhtml/ mm5429a1.htm.

2. Seward JF, Watson BM, Peterson CL, et al. Varicella disease after introduction of varicella vaccine in the United States, 1995-2000. JAMA 2002;287:606-11.

3. Dworkin MS, Jennings CE, Roth-Thomas J, Lang JE, Stukenberg C, Lumpkin JR. An outbreak of varicella among children attending preschool and elementary school in Illinois. Clin Infect Dis 2002;35:102-4.

4. Tugwell BD, Lee LE, Gillette H, Lorber EM, Hedberg K, Cieslak PR. Chickenpox outbreak in a highly vaccinated school population. Pediatrics 2004; 113:455-9.

5. Lopez AS, Guris D, Zimmerman L, et al. One dose of varicella vaccine does not prevent school outbreaks — is it time for a second dose? Pediatrics 2006;117:e1070-7.

6. CDC. ACIP provisional recommendations for prevention of varicella. Advisory Committee on Immunization Practices. Available at http:// www.cdc.gov/nip/vaccine/varicella/varicella_acip_recs_prov_june_2006.pdf.

7. Kuter B, Matthews H, Shinefield H, et al. Ten year follow-up of healthy children who received one or two injections of varicella vaccine. Pediatr Infect Dis 2004;23:132-7.

8. Council of State and Territorial Epidemiologists. Position Statement 02-ID-06: varicella surveillance. Kansas City, MO: Council of State and Territorial Epidemiologists; 2002. Available at http://www.cste.org/ position\%20statements/02-ID-06.pdf.

9. CDC. Varicella [Chapter 14]. In: Wharton M, ed. Vaccine preventable disease. Surveillance manual. 3rd edition. Atlanta, GA: US Department of Health and Human Services, CDC; 2002. Available at http:// www.cdc.gov/nip. 


\section{West Nile Virus Activity - United States, January 1-September 12, 2006}

This report summarizes West Nile virus (WNV) surveillance data reported to CDC through ArboNET as of 3 a.m. Mountain Daylight Time, September 12, 2006. A total of 36 states and the District of Columbia had reported 1,634 cases of human WNV illness to CDC (Figure, Table). A total of $921(57 \%)$ cases for which such data were available occurred in males; median age of patients was 51 years (range: 3 months95 years). Dates of illness onset ranged from January 6 to September 10; a total of 52 cases were fatal.

A total of 159 presumptive West Nile viremic blood donors (PVDs) have been reported to ArboNET during 2006. Of these, 33 were reported from Nebraska; 25 from Texas; 12 from California; 11 from Utah; nine from Wisconsin; eight each were reported from Idaho and Iowa; seven each from Louisiana and South Dakota; six from North Dakota; five each from Minnesota and Mississippi; four from Missouri; three each from Kansas, Kentucky, and Oklahoma; two each from Colorado and Nevada; and one each from Arizona, Illinois, Montana, New York, Oregon, and Wyoming. Of the 159 PVDs, one person aged 73 years subsequently had neuroinvasive illness, and 36 persons (median age: 46 years [range: 18-67 years]) subsequently had West Nile fever.

In addition, 2,138 dead corvids and 503 other dead birds with WNV infection have been reported in 39 states and New York City during 2006. WNV infections have been reported in horses in 27 states, in one squirrel in Kansas, and in one unidentified animal species in Wyoming. WNV seroconversions have been reported in 495 sentinel chicken

FIGURE. Areas reporting West Nile virus (WNV) activity United States, 2006*

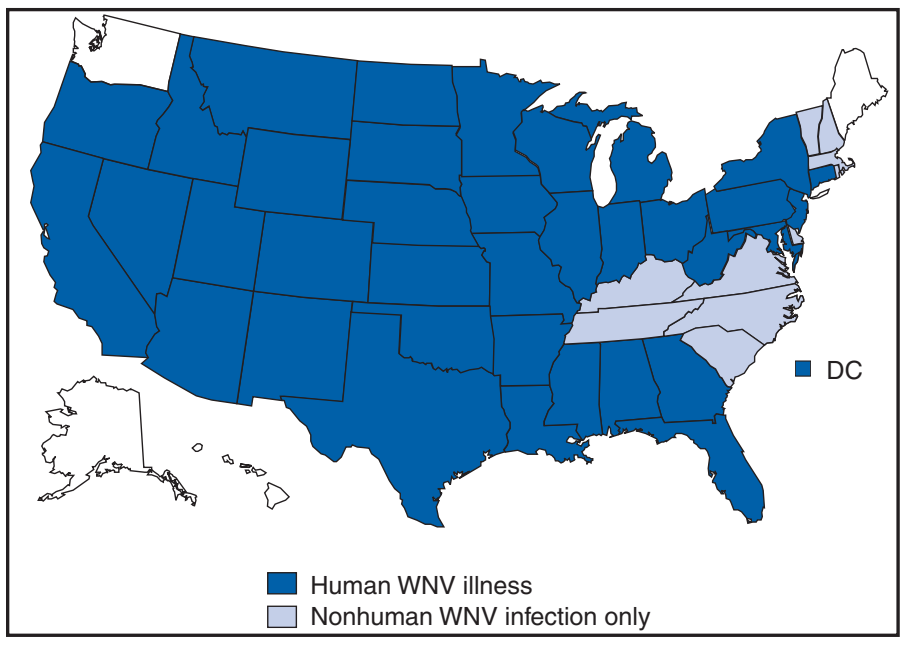

${ }^{*}$ As of September 12, 2006.
TABLE. Number of human cases of West Nile virus (WNV) illness, by state - United States, 2006*

\begin{tabular}{|c|c|c|c|c|c|}
\hline State & $\begin{array}{c}\text { Neuroinvasive } \\
\text { disease }^{\dagger}\end{array}$ & $\begin{array}{l}\text { West } \\
\text { Nile } \\
\text { fever }^{\S}\end{array}$ & $\begin{array}{c}\text { Other } \\
\text { clinical/ } \\
\text { unspecified" }\end{array}$ & $\begin{array}{c}\text { Total } \\
\text { reported } \\
\text { to CDC** }\end{array}$ & Deaths \\
\hline Alabama & 4 & 0 & 0 & 4 & 0 \\
\hline Arizona & 7 & 4 & 2 & 13 & 0 \\
\hline Arkansas & 7 & 2 & 0 & 9 & 0 \\
\hline California & 42 & 108 & 9 & 159 & 2 \\
\hline Colorado & 18 & 57 & 0 & 75 & 1 \\
\hline Connecticut & 5 & 2 & 0 & 7 & 1 \\
\hline District of Colu & lumbia 0 & 1 & 0 & 1 & 0 \\
\hline Florida & 2 & 0 & 0 & 2 & 0 \\
\hline Georgia & 2 & 2 & 1 & 5 & 1 \\
\hline Idaho & 62 & 257 & 6 & 325 & 5 \\
\hline Illinois & 53 & 30 & 11 & 94 & 4 \\
\hline Indiana & 1 & 0 & 0 & 1 & 0 \\
\hline lowa & 12 & 7 & 0 & 19 & 0 \\
\hline Kansas & 13 & 9 & 0 & 22 & 3 \\
\hline Louisiana & 38 & 26 & 0 & 64 & 0 \\
\hline Maryland & 0 & 0 & 1 & 1 & 0 \\
\hline Michigan & 10 & 0 & 4 & 14 & 0 \\
\hline Minnesota & 22 & 30 & 0 & 52 & 3 \\
\hline Mississippi & 34 & 36 & 0 & 70 & 3 \\
\hline Missouri & 18 & 5 & 1 & 24 & 2 \\
\hline Montana & 3 & 7 & 0 & 10 & 0 \\
\hline Nebraska & 15 & 41 & 0 & 56 & 1 \\
\hline Nevada & 30 & 60 & 9 & 99 & 1 \\
\hline New Jersey & 1 & 1 & 1 & 3 & 0 \\
\hline New Mexico & 1 & 2 & 0 & 3 & 0 \\
\hline New York & 5 & 2 & 1 & 8 & 0 \\
\hline North Dakota & 13 & 88 & 0 & 101 & 1 \\
\hline Ohio & 8 & 3 & 0 & 11 & 0 \\
\hline Oklahoma & 15 & 6 & 1 & 22 & 5 \\
\hline Oregon & 2 & 19 & 1 & 22 & 0 \\
\hline Pennsylvania & 5 & 1 & 0 & 6 & 1 \\
\hline South Dakota & 30 & 56 & 0 & 86 & 1 \\
\hline Texas & 106 & 23 & 0 & 129 & 13 \\
\hline Utah & 34 & 47 & 0 & 81 & 3 \\
\hline West Virginia & 1 & 0 & 0 & 1 & 0 \\
\hline Wisconsin & 3 & 3 & 0 & 6 & 0 \\
\hline Wyoming & 8 & 17 & 4 & 29 & 1 \\
\hline Total & 630 & 952 & 52 & 1,634 & 52 \\
\hline
\end{tabular}

* As of September 12, 2006.

† Cases with neurologic manifestations (i.e., West Nile meningitis, West Nile encephalitis, and West Nile myelitis).

$\S$ Cases with no evidence of neuroinvasion.

I IIInesses for which sufficient clinical information was not provided.

** Total number of human cases of WNV illness reported to ArboNET by state and local health departments.

flocks in 10 states (Arizona, Arkansas, California, Florida, Iowa, North Carolina, North Dakota, Pennsylvania, Utah, and Virginia). Five seropositive sentinel horses were reported in Montana. A total of 7,492 WNV-positive mosquito pools have been reported from 36 states, the District of Columbia, and New York City.

Additional information about national WNV activity is available from CDC at http://www.cdc.gov/ncidod/dvbid/ westnile/index.htm and at http://westnilemaps.usgs.gov. 


\section{Notice to Readers}

\section{Epidemiology in Action Course - October 23-November 3, 2006}

The Rollins School of Public Health's Hubert Department of Global Health and CDC's Office of Workforce and Career Development will cosponsor a course, Epidemiology in Action, October 23-November 3, 2006, at the Emory University campus in Atlanta, Georgia. The course is designed for state and local public health workers.

The course emphasizes the practical application of epidemiology to public health problems and will consist of lectures, workshops, classroom exercises (including actual epidemiologic problems), and roundtable discussions. Topics include descriptive epidemiology and biostatistics, analytic epidemiology, epidemic investigations, public health surveillance, surveys and sampling, Epi Info (Windows version) training, and discussions of selected prevalent diseases. Tuition is charged.

Additional information and applications are available from Emory University, Hubert Department of Global Health (attention: Pia), 1518 Clifton Road NE, Room 746, Atlanta, GA 30322; by telephone, 404-727-3485; fax, 404-727-4590; online at http://www.sph.emory.edu/epicourses; or by e-mail, pvaleri@sph.emory.edu.

\section{Notice to Readers}

\section{Preventive Medicine Residency Application Deadline - October 11, 2006}

The Preventive Medicine Residency (PMR) is accepting applications from physicians with public health and applied epidemiologic practice experience who seek to become preventive medicine/population health specialists and public health leaders. The PMR prepares physicians for leadership roles in public health at federal, state, and local levels through instruction and supervised practical experiences focused on translating epidemiology to public health practice, management, and policy and program development. Residents spend the practicum year at CDC or in a state or local health department.

PMR alumni occupy many leadership positions at CDC, at state and local health departments, and in academia and private-sector agencies. Completion of the PMR, which is accredited by the Accreditation Council for Graduate Medical Education for 12 months of practicum training, qualifies graduates to apply for certification by the American Board of Preventive Medicine in Public Health and General Preventive Medicine.

Applications are being accepted for the class that begins in mid-June 2007. Application materials must be postmarked by October 11, 2006. Additional information regarding the residency, eligibility criteria, and application process is available at http://www.cdc.gov/epo/dapht/pmr/pmr.htm or by telephone, 404-498-6140.

\section{Errata: Vol. 55, No. RR-11}

In the MMWR Recommendations and Reports, "Sexually Transmitted Diseases Treatment Guidelines, 2006," the following errors occurred:

On page 42, in the section "Chlamydial Infections Among Children" under "Diagnostic Considerations," the second recommended regimen should read: Recommended Regimen for Children Who Weigh $\geq 45 \mathrm{~kg}$ but Who Are Aged $<\mathbf{8}$ Years.

On page 48, in the section "Gonococcal Infections Among Children" under "Diagnostic Considerations," the first recommended regimen should read: Recommended Regimens for Children Who Weigh $>45 \mathrm{~kg}$.

On page 59, under "Recommended Regimen A," the daily dosage for Ofloxacin was incorrect. It should read: Ofloxacin $400 \mathrm{mg}$ orally twice daily for 14 days*. 


\section{QuickStats}

FROM THE NATIONAL CENTER FOR HEALTH STATISTICS

\section{Percentage of Parents* Who Were Married or Cohabiting ${ }^{\dagger}$ at Birth of First Child, by Race/Ethnicity and Sex — United States, 2002 Survey}

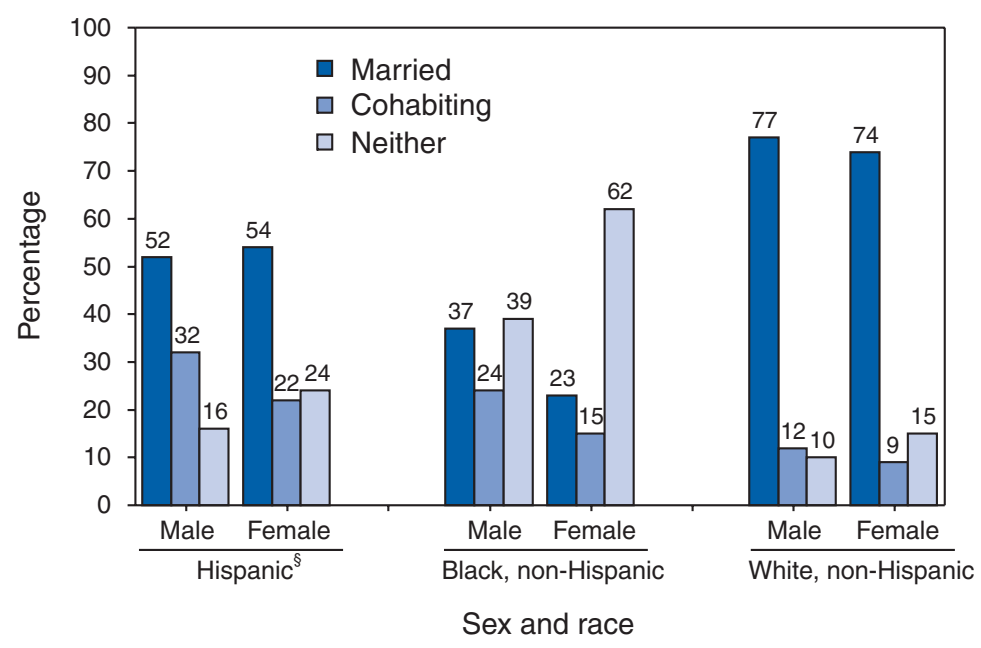

* Based on independent samples of males and females aged 15-44 years.

† Living together.

$\S$ Might be of any race.

According to 2002 survey data, among non-Hispanic whites, the birth of the first child occurred during marriage for $77 \%$ of males and $74 \%$ of females. Among Hispanics, the birth of the first child occurred during marriage for $52 \%$ of males and $54 \%$ of females, and, among non-Hispanic blacks, it occurred during marriage for $37 \%$ of males and $23 \%$ of females.

SOURCE: Martinez GM, Chandra A, Abma JC, Jones J, Mosher WD. Fertility, contraception, and fatherhood: data on men and women from cycle 6 (2002) of the National Survey of Family Growth. Vital Health Stat 2006;23(26). Available at http://www.cdc.gov/nchs/nsfg.htm. 
TABLE I. Provisional cases of infrequently reported notifiable diseases $(<1,000$ cases reported during the preceding year) - United States, week ending September 9, 2006 (36th Week)*

\begin{tabular}{|c|c|c|c|c|c|c|c|c|c|}
\hline \multirow[b]{2}{*}{ Disease } & \multirow{2}{*}{$\begin{array}{l}\text { Current } \\
\text { week }\end{array}$} & \multirow{2}{*}{$\begin{array}{l}\text { Cum } \\
2006\end{array}$} & \multirow{2}{*}{$\begin{array}{c}\text { 5-year } \\
\text { weekly } \\
\text { average }^{\dagger}\end{array}$} & \multicolumn{5}{|c|}{ Total cases reported for previous years } & \multirow[b]{2}{*}{ States reporting cases during current week (No.) } \\
\hline & & & & 2005 & 2004 & 2003 & 2002 & 2001 & \\
\hline Anthrax & - & 1 & 0 & - & - & - & 2 & 23 & \\
\hline \multicolumn{10}{|l|}{ Botulism: } \\
\hline foodborne & - & 3 & 1 & 19 & 16 & 20 & 28 & 39 & \\
\hline infant & - & 81 & 2 & 90 & 87 & 76 & 69 & 97 & \\
\hline other (wound \& unspecified) & - & 40 & 1 & 33 & 30 & 33 & 21 & 19 & \\
\hline Brucellosis & - & 67 & 2 & 122 & 114 & 104 & 125 & 136 & \\
\hline Chancroid & - & 20 & 1 & 17 & 30 & 54 & 67 & 38 & \\
\hline Cholera & - & 5 & 0 & 8 & 5 & 2 & 2 & 3 & \\
\hline Cyclosporiasis $§$ & 1 & 87 & 3 & 734 & 171 & 75 & 156 & 147 & $\mathrm{FL}(1)$ \\
\hline Diphtheria & - & - & 0 & - & - & 1 & 1 & 2 & \\
\hline \multicolumn{10}{|l|}{ Domestic arboviral diseases $\$, \eta$ : } \\
\hline California serogroup & - & 12 & 8 & 78 & 112 & 108 & 164 & 128 & \\
\hline eastern equine & - & 4 & 1 & 21 & 6 & 14 & 10 & 9 & \\
\hline Powassan & - & 1 & - & 1 & 1 & - & 1 & $\mathrm{~N}$ & \\
\hline St. Louis & - & 2 & 3 & 10 & 12 & 41 & 28 & 79 & \\
\hline western equine & - & - & - & - & - & - & - & - & \\
\hline \multicolumn{10}{|l|}{ Ehrlichiosis§: } \\
\hline human granulocytic & 2 & 236 & 12 & 790 & 537 & 362 & 511 & 261 & NY (2) \\
\hline human monocytic & 5 & 242 & 10 & 522 & 338 & 321 & 216 & 142 & NY (3), MI (1), AR (1) \\
\hline human (other \& unspecified) & 2 & 104 & 2 & 122 & 59 & 44 & 23 & 6 & $\mathrm{AR}(1), \mathrm{OK}(1)$ \\
\hline \multicolumn{10}{|l|}{$\begin{array}{l}\text { Haemophilus influenzae, } \\
\text { invasive disease (age }<5 \mathrm{yrs} \text { ): }\end{array}$} \\
\hline serotype b & - & 5 & 0 & 9 & 19 & 32 & 34 & - & \\
\hline nonserotype b & - & 58 & 2 & 135 & 135 & 117 & 144 & - & \\
\hline unknown serotype & 2 & 146 & 2 & 217 & 177 & 227 & 153 & - & MA (1), AZ (1) \\
\hline Hansen disease ${ }^{\S}$ & - & 44 & 1 & 88 & 105 & 95 & 96 & 79 & \\
\hline Hantavirus pulmonary syndrome ${ }^{\S}$ & - & 21 & 0 & 29 & 24 & 26 & 19 & 8 & \\
\hline Hemolytic uremic syndrome, postdiarrheal $\$$ & 4 & 127 & 6 & 221 & 200 & 178 & 216 & 202 & MN (1), NC (1), TN (1), CA (1) \\
\hline Hepatitis C viral, acute & 2 & 522 & 33 & 771 & 713 & 1,102 & 1,835 & 3,976 & MD (1), TN (1) \\
\hline HIV infection, pediatric (age $<13 \mathrm{yrs})^{\text {s.t† }}$ & - & 52 & 4 & 380 & 436 & 504 & 420 & 543 & \\
\hline Influenza-associated pediatric mortality $\$, \S \S$, ๆๆ & - & 41 & 0 & 49 & - & $\mathrm{N}$ & $\mathrm{N}$ & $\mathrm{N}$ & \\
\hline Listeriosis & 17 & 411 & 19 & 892 & 753 & 696 & 665 & 613 & $\begin{array}{c}\mathrm{ME}(1), \mathrm{RI}(1), \mathrm{NY}(1), \mathrm{OH}(4), \mathrm{KS}(1), \mathrm{MD}(1) \\
\mathrm{NC}(1), \mathrm{FL}(2), \mathrm{AL}(1), \mathrm{OK}(1), \mathrm{CO}(1), \mathrm{CA}(2)\end{array}$ \\
\hline Measles & $2^{\star \star \star}$ & 43 & 1 & 66 & 37 & 56 & 44 & 116 & FL (2) \\
\hline \multicolumn{10}{|l|}{ Meningococcal disease, ${ }^{\mathrm{tt}}$ invasive: } \\
\hline$A, C, Y, \& W-135$ & 1 & 153 & 3 & 297 & - & - & - & - & $\mathrm{FL}(1)$ \\
\hline serogroup B & 2 & 103 & 1 & 157 & - & - & - & - & FL (2) \\
\hline other serogroup & - & 13 & 0 & 27 & - & - & - & - & \\
\hline Mumps & 10 & 5,603 & 4 & 314 & 258 & 231 & 270 & 266 & PA (1), KS (4), AL (1), UT (1), OR (2), CA (1) \\
\hline Plague & - & 7 & 0 & 8 & 3 & 1 & 2 & 2 & \\
\hline Poliomyelitis, paralytic & - & - & - & 1 & - & - & - & - & \\
\hline Psittacosis $\S$ & - & 15 & 0 & 19 & 12 & 12 & 18 & 25 & \\
\hline$Q$ fever $\S$ & 2 & 101 & 2 & 139 & 70 & 71 & 61 & 26 & NC (1), TN (1) \\
\hline Rabies, human & - & 1 & 0 & 2 & 7 & 2 & 3 & 1 & \\
\hline Rubella & 1 & 6 & 0 & 11 & 10 & 7 & 18 & 23 & $\mathrm{FL}(1)$ \\
\hline Rubella, congenital syndrome & - & 1 & - & 1 & - & 1 & 1 & 3 & \\
\hline SARS-CoV§,§§ & - & - & - & - & - & 8 & $\mathrm{~N}$ & $\mathrm{~N}$ & \\
\hline Smallpox ${ }^{\S}$ & - & - & - & - & - & - & - & - & \\
\hline Streptococcal toxic-shock syndrome ${ }^{\S}$ & - & 74 & 1 & 129 & 132 & 161 & 118 & 77 & \\
\hline \multicolumn{10}{|l|}{ Streptococcus pneumoniae, } \\
\hline invasive disease (age <5 yrs) & 8 & 745 & 7 & 1,257 & 1,162 & 845 & 513 & 498 & RI (3), NY (1), OH (1), IN (1), MD (1), OK (1) \\
\hline Syphilis, congenital (age <1 yr) & - & 174 & 8 & 361 & 353 & 413 & 412 & 441 & \\
\hline Tetanus & 1 & 16 & 0 & 27 & 34 & 20 & 25 & 37 & MI (1) \\
\hline Toxic-shock syndrome (other than streptococcal)§ & $\S 1$ & 65 & 2 & 96 & 95 & 133 & 109 & 127 & NE (1) \\
\hline Trichinellosis & - & 10 & 0 & 19 & 5 & 6 & 14 & 22 & \\
\hline Tularemia§ & 1 & 57 & 4 & 154 & 134 & 129 & 90 & 129 & $\mathrm{AR}(1)$ \\
\hline Typhoid fever & 2 & 183 & 10 & 324 & 322 & 356 & 321 & 368 & $\mathrm{OH}(1), \mathrm{FL}(1)$ \\
\hline Vancomycin-intermediate Staphylococcus aureus & $s^{\S}-$ & 2 & 0 & 2 & - & $\mathrm{N}$ & $\mathrm{N}$ & $\mathrm{N}$ & \\
\hline Vancomycin-resistant Staphylococcus aureus ${ }^{\S}$ & - & - & - & 3 & 1 & $\mathrm{~N}$ & $\mathrm{~N}$ & $\mathrm{~N}$ & \\
\hline Yellow fever & - & - & - & - & - & - & 1 & - & \\
\hline
\end{tabular}

-: No reported cases. $\quad \mathrm{N}$ : Not notifiable. Cum: Cumulative year-to-date counts.

* Incidence data for reporting years 2005 and 2006 are provisional, whereas data for 2001, 2002, 2003, and 2004 are finalized.

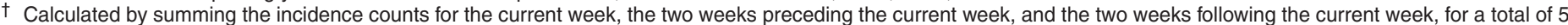
preceding years. Additional information is available at http://www.cdc.gov/epo/dphsi/phs/files/5yearweeklyaverage.pdf.

$\S$ Not notifiable in all states.

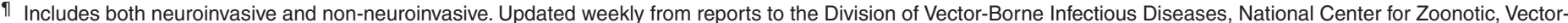
Borne, and Enteric Diseases (proposed) (ArboNET Surveillance)

** Data for H. influenzae (all ages, all serotypes) are available in Table II.

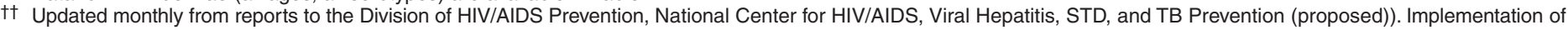
HIV reporting influences the number of cases reported. Data for HIV/AIDS are available in Table IV quarterly.

$\S \S$ Updated weekly from reports to the Influenza Division, National Center for Immunization and Respiratory Diseases (proposed).

१ๆ A total of 46 cases were reported since the beginning of the 2005-06 flu season (October 2, 2005 [week 40]).

*** Of the two measles cases were reported for the current week, one was indigenous and one was imported from another country.

t†† Data for meningococcal disease (all serogroups and unknown serogroups) are available in Table II. 
TABLE II. Provisional cases of selected notifiable diseases, United States, weeks ending September 9, 2006, and September 10, 2005 (36th Week)*

\begin{tabular}{|c|c|c|c|c|c|c|c|c|c|c|c|c|c|c|c|}
\hline \multirow[b]{3}{*}{ Reporting area } & \multicolumn{5}{|c|}{ Chlamydia $^{\dagger}$} & \multicolumn{5}{|c|}{ Coccidioidomycosis } & \multicolumn{5}{|c|}{ Cryptosporidiosis } \\
\hline & \multirow{2}{*}{$\begin{array}{c}\text { Current } \\
\text { week }\end{array}$} & \multicolumn{2}{|c|}{$\begin{array}{l}\text { Previous } \\
52 \text { weeks }\end{array}$} & \multirow{2}{*}{$\begin{array}{l}\text { Cum } \\
2006\end{array}$} & \multirow{2}{*}{$\begin{array}{l}\text { Cum } \\
2005\end{array}$} & \multirow{2}{*}{$\begin{array}{c}\text { Current } \\
\text { week }\end{array}$} & \multicolumn{2}{|c|}{$\begin{array}{l}\text { Previous } \\
52 \text { weeks }\end{array}$} & \multirow{2}{*}{$\begin{array}{l}\text { Cum } \\
2006\end{array}$} & \multirow{2}{*}{$\begin{array}{l}\text { Cum } \\
2005 \\
\end{array}$} & \multirow{2}{*}{$\begin{array}{c}\text { Current } \\
\text { week }\end{array}$} & \multicolumn{2}{|c|}{$\begin{array}{l}\text { Previous } \\
52 \text { weeks } \\
\end{array}$} & \multirow{2}{*}{$\begin{array}{l}\text { Cum } \\
2006\end{array}$} & \multirow{2}{*}{$\begin{array}{c}\text { Cum } \\
2005\end{array}$} \\
\hline & & Med & Max & & & & Med & $\operatorname{Max}$ & & & & Med & Max & & \\
\hline United States & 8,008 & 18,748 & 35,170 & 644,074 & 661,251 & 57 & 149 & 1,643 & 5,839 & 2,861 & 112 & 67 & 594 & 2,582 & 4,029 \\
\hline $\begin{array}{l}\text { New England } \\
\text { Connecticut } \\
\text { Maine } \\
\text { Massachusetts } \\
\text { New Hampshire } \\
\text { Rhode Island } \\
\text { Vermont } \$\end{array}$ & $\begin{array}{r}429 \\
29 \\
34 \\
323 \\
22 \\
-1\end{array}$ & $\begin{array}{r}631 \\
169 \\
43 \\
293 \\
36 \\
62 \\
18\end{array}$ & $\begin{array}{r}1,550 \\
1,214 \\
74 \\
448 \\
64 \\
95 \\
43\end{array}$ & $\begin{array}{r}21,993 \\
6,165 \\
1,528 \\
10,132 \\
1,276 \\
2,131 \\
761\end{array}$ & $\begin{array}{r}22,284 \\
6,750 \\
1,509 \\
9,771 \\
1,277 \\
2,303 \\
674\end{array}$ & $\begin{array}{l}\bar{N} \\
\mathrm{~N} \\
- \\
- \\
\mathrm{N}\end{array}$ & $\begin{array}{l}0 \\
0 \\
0 \\
0 \\
0 \\
0 \\
0\end{array}$ & $\begin{array}{l}0 \\
0 \\
0 \\
0 \\
0 \\
0 \\
0\end{array}$ & $\begin{array}{l}\bar{N} \\
\mathrm{~N} \\
- \\
- \\
\mathrm{N}\end{array}$ & $\begin{array}{l}\bar{N} \\
\mathrm{~N} \\
- \\
- \\
\mathrm{N}\end{array}$ & $\begin{array}{l}\frac{5}{-} \\
\frac{2}{3}\end{array}$ & $\begin{array}{l}4 \\
0 \\
0 \\
2 \\
1 \\
0 \\
0\end{array}$ & $\begin{array}{r}35 \\
21 \\
3 \\
15 \\
4 \\
6 \\
5\end{array}$ & $\begin{array}{r}194 \\
21 \\
22 \\
88 \\
24 \\
7 \\
32\end{array}$ & $\begin{array}{r}209 \\
38 \\
20 \\
97 \\
22 \\
5 \\
27\end{array}$ \\
\hline $\begin{array}{l}\text { Mid. Atlantic } \\
\text { New Jersey } \\
\text { New York (Upstate) } \\
\text { New York City } \\
\text { Pennsylvania }\end{array}$ & $\begin{array}{r}942 \\
135 \\
344 \\
- \\
463\end{array}$ & $\begin{array}{r}2,345 \\
363 \\
502 \\
710 \\
746\end{array}$ & $\begin{array}{r}3,696 \\
500 \\
1,727 \\
1,584 \\
1,075\end{array}$ & $\begin{array}{l}79,747 \\
12,280 \\
16,184 \\
24,360 \\
26,923\end{array}$ & $\begin{array}{l}80,552 \\
13,349 \\
15,928 \\
25,832 \\
25,443\end{array}$ & $\begin{array}{l}-\bar{N} \\
N \\
N \\
N\end{array}$ & $\begin{array}{l}0 \\
0 \\
0 \\
0 \\
0\end{array}$ & $\begin{array}{l}0 \\
0 \\
0 \\
0 \\
0\end{array}$ & $\begin{array}{l}- \\
\mathrm{N} \\
\mathrm{N} \\
\mathrm{N} \\
\mathrm{N}\end{array}$ & $\begin{array}{l}- \\
N \\
N \\
N\end{array}$ & $\frac{11}{6}$ & $\begin{array}{r}10 \\
0 \\
3 \\
1 \\
5\end{array}$ & $\begin{array}{r}444 \\
5 \\
441 \\
10 \\
21\end{array}$ & $\begin{array}{r}328 \\
9 \\
105 \\
44 \\
170\end{array}$ & $\begin{array}{r}1,548 \\
41 \\
1,258 \\
92 \\
157\end{array}$ \\
\hline $\begin{array}{l}\text { E.N. Central } \\
\text { Illinois } \\
\text { Indiana } \\
\text { Michigan } \\
\text { Ohio } \\
\text { Wisconsin }\end{array}$ & $\begin{array}{r}1,291 \\
546 \\
260 \\
322 \\
80 \\
83\end{array}$ & $\begin{array}{r}3,110 \\
960 \\
399 \\
614 \\
704 \\
398\end{array}$ & $\begin{array}{r}12,578 \\
1,686 \\
552 \\
9,888 \\
1,446 \\
531\end{array}$ & $\begin{array}{r}106,581 \\
34,749 \\
13,607 \\
22,027 \\
23,041 \\
13,157\end{array}$ & $\begin{array}{r}110,180 \\
34,585 \\
13,689 \\
18,090 \\
29,966 \\
13,850\end{array}$ & $\begin{array}{l}- \\
\frac{N}{N} \\
-\end{array}$ & $\begin{array}{l}1 \\
0 \\
0 \\
0 \\
0 \\
0\end{array}$ & $\begin{array}{l}3 \\
0 \\
0 \\
3 \\
1 \\
0\end{array}$ & $\begin{array}{r}32 \\
N \\
28 \\
4 \\
N\end{array}$ & $\begin{array}{l}\frac{8}{N} \\
\frac{8}{N}\end{array}$ & $\frac{15}{\frac{1}{14}}$ & $\begin{array}{r}16 \\
2 \\
1 \\
2 \\
5 \\
5\end{array}$ & $\begin{array}{r}162 \\
13 \\
13 \\
7 \\
109 \\
38\end{array}$ & $\begin{array}{r}642 \\
72 \\
42 \\
80 \\
228 \\
220\end{array}$ & $\begin{array}{r}858 \\
109 \\
38 \\
73 \\
305 \\
333\end{array}$ \\
\hline $\begin{array}{l}\text { W.N. Central } \\
\text { lowa } \\
\text { Kansas } \\
\text { Minnesota } \\
\text { Missouri } \\
\text { Nebraska§ } \\
\text { North Dakota } \\
\text { South Dakota }\end{array}$ & $\begin{array}{r}631 \\
51 \\
157 \\
- \\
301 \\
58 \\
11 \\
53\end{array}$ & $\begin{array}{r}1,142 \\
154 \\
157 \\
230 \\
439 \\
95 \\
32 \\
51\end{array}$ & $\begin{array}{r}1,457 \\
225 \\
269 \\
344 \\
567 \\
176 \\
58 \\
117\end{array}$ & $\begin{array}{r}39,941 \\
5,555 \\
5,324 \\
7,044 \\
15,508 \\
3,609 \\
1,075 \\
1,826\end{array}$ & $\begin{array}{r}40,736 \\
4,889 \\
5,060 \\
8,555 \\
15,627 \\
3,568 \\
1,116 \\
1,921\end{array}$ & $\begin{array}{l}-\bar{N} \\
N \\
- \\
-N \\
N \\
N\end{array}$ & $\begin{array}{l}0 \\
0 \\
0 \\
0 \\
0 \\
0 \\
0 \\
0\end{array}$ & $\begin{array}{r}12 \\
0 \\
0 \\
12 \\
0 \\
1 \\
0 \\
0\end{array}$ & $\begin{array}{l}\bar{N} \\
\mathrm{~N} \\
- \\
-\mathrm{N} \\
\mathrm{N} \\
\mathrm{N}\end{array}$ & $\begin{array}{l}4 \\
N \\
N \\
3 \\
1 \\
N \\
N \\
N\end{array}$ & $\begin{array}{r}19 \\
3 \\
1 \\
11 \\
3 \\
1 \\
-\end{array}$ & $\begin{array}{r}11 \\
1 \\
1 \\
2 \\
2 \\
1 \\
0 \\
1\end{array}$ & $\begin{array}{r}52 \\
20 \\
8 \\
22 \\
9 \\
9 \\
16 \\
4 \\
6\end{array}$ & $\begin{array}{r}447 \\
103 \\
50 \\
126 \\
64 \\
56 \\
7 \\
41\end{array}$ & $\begin{array}{r}439 \\
97 \\
29 \\
82 \\
195 \\
14 \\
\frac{2}{22}\end{array}$ \\
\hline $\begin{array}{l}\text { S. Atlantic } \\
\text { Delaware } \\
\text { District of Columbia } \\
\text { Florida } \\
\text { Georgia } \\
\text { Maryland§} \\
\text { North Carolina } \\
\text { South Carolina } \\
\text { Virginia§ } \\
\text { West Virginia }\end{array}$ & $\begin{array}{r}1,534 \\
41 \\
9 \\
520 \\
27 \\
266 \\
178 \\
140 \\
353 \\
-\end{array}$ & $\begin{array}{r}3,393 \\
70 \\
54 \\
925 \\
635 \\
341 \\
562 \\
290 \\
425 \\
58\end{array}$ & $\begin{array}{r}4,925 \\
92 \\
103 \\
1,106 \\
2,142 \\
486 \\
1,772 \\
1,306 \\
840 \\
226\end{array}$ & $\begin{array}{r}122,721 \\
2,433 \\
1,672 \\
33,035 \\
19,868 \\
12,121 \\
22,960 \\
12,236 \\
16,201 \\
2,195\end{array}$ & $\begin{array}{r}123,237 \\
2,259 \\
2,611 \\
29,931 \\
21,731 \\
12,726 \\
22,985 \\
12,738 \\
16,438 \\
1,818\end{array}$ & $\begin{array}{l}\bar{N} \\
\bar{N} \\
- \\
N \\
N \\
N \\
N\end{array}$ & $\begin{array}{l}0 \\
0 \\
0 \\
0 \\
0 \\
0 \\
0 \\
0 \\
0 \\
0\end{array}$ & $\begin{array}{l}1 \\
0 \\
0 \\
0 \\
0 \\
1 \\
0 \\
0 \\
0 \\
0\end{array}$ & $\begin{array}{l}3 \\
\mathrm{~N} \\
\mathrm{~N} \\
\\
3 \\
\mathrm{~N} \\
\mathrm{~N} \\
\mathrm{~N} \\
\mathrm{~N}\end{array}$ & $\begin{array}{r}1 \\
\mathrm{~N} \\
\mathrm{~N} \\
\\
1 \\
\mathrm{~N} \\
\mathrm{~N} \\
\mathrm{~N} \\
\mathrm{~N}\end{array}$ & $\begin{array}{l}30 \\
- \\
-27 \\
- \\
-2 \\
1 \\
-\end{array}$ & $\begin{array}{r}14 \\
0 \\
0 \\
6 \\
3 \\
0 \\
1 \\
1 \\
1 \\
0\end{array}$ & $\begin{array}{r}54 \\
3 \\
3 \\
28 \\
9 \\
4 \\
10 \\
12 \\
8 \\
3\end{array}$ & $\begin{array}{r}523 \\
7 \\
11 \\
248 \\
116 \\
11 \\
55 \\
43 \\
28 \\
4\end{array}$ & $\begin{array}{r}386 \\
3 \\
7 \\
165 \\
88 \\
19 \\
44 \\
15 \\
35 \\
10\end{array}$ \\
\hline $\begin{array}{l}\text { E.S. Central } \\
\text { Alabama }^{\S} \\
\text { Kentucky } \\
\text { Mississippi } \\
\text { Tennessee }^{\S}\end{array}$ & $\begin{array}{r}653 \\
50 \\
29 \\
228 \\
346\end{array}$ & $\begin{array}{r}1,414 \\
382 \\
155 \\
384 \\
494\end{array}$ & $\begin{array}{r}1,943 \\
756 \\
402 \\
801 \\
602\end{array}$ & $\begin{array}{r}50,788 \\
14,066 \\
6,137 \\
13,230 \\
17,355\end{array}$ & $\begin{array}{r}48,121 \\
10,594 \\
6,446 \\
14,991 \\
16,090\end{array}$ & $\begin{array}{l}-\bar{N} \\
N \\
\bar{N}\end{array}$ & $\begin{array}{l}0 \\
0 \\
0 \\
0 \\
0\end{array}$ & $\begin{array}{l}0 \\
0 \\
0 \\
0 \\
0\end{array}$ & $\begin{array}{l}\bar{N} \\
\mathrm{~N} \\
\bar{N}\end{array}$ & $\begin{array}{l}\bar{N} \\
\frac{N}{N}\end{array}$ & $\frac{3}{\frac{2}{1}}$ & $\begin{array}{l}3 \\
0 \\
1 \\
0 \\
1\end{array}$ & $\begin{array}{r}29 \\
6 \\
25 \\
1 \\
5\end{array}$ & $\begin{array}{r}99 \\
37 \\
27 \\
8 \\
27\end{array}$ & $\begin{array}{r}117 \\
17 \\
71 \\
29\end{array}$ \\
\hline $\begin{array}{l}\text { W.S. Central } \\
\text { Arkansas } \\
\text { Louisiana } \\
\text { Oklahoma } \\
\text { Texas }^{\S}\end{array}$ & $\begin{array}{r}904 \\
134 \\
5 \\
177 \\
588\end{array}$ & $\begin{array}{r}2,125 \\
162 \\
254 \\
226 \\
1,396\end{array}$ & $\begin{array}{r}3,605 \\
240 \\
761 \\
2,159 \\
1,777\end{array}$ & $\begin{array}{r}73,541 \\
5,345 \\
9,642 \\
7,979 \\
50,575\end{array}$ & $\begin{array}{r}77,855 \\
5,887 \\
12,910 \\
7,797 \\
51,261\end{array}$ & $\begin{array}{l}- \\
- \\
N \\
N\end{array}$ & $\begin{array}{l}0 \\
0 \\
0 \\
0 \\
0\end{array}$ & $\begin{array}{l}1 \\
0 \\
1 \\
0 \\
0\end{array}$ & $\frac{-}{-}$ & $\begin{array}{l}- \\
\mathrm{N} \\
\mathrm{N} \\
\mathrm{N}\end{array}$ & $\frac{1}{-}$ & $\begin{array}{l}3 \\
0 \\
0 \\
1 \\
1\end{array}$ & $\begin{array}{r}24 \\
2 \\
14 \\
2 \\
19\end{array}$ & $\begin{array}{r}96 \\
14 \\
8 \\
25 \\
49\end{array}$ & $\begin{array}{r}131 \\
3 \\
49 \\
33 \\
46\end{array}$ \\
\hline $\begin{array}{l}\text { Mountain } \\
\text { Arizona } \\
\text { Colorado } \\
\text { Idaho§ } \\
\text { Montana } \\
\text { Nevada } \\
\text { New Mexico§ } \\
\text { Utah } \\
\text { Wyoming }\end{array}$ & $\begin{array}{r}321 \\
104 \\
53 \\
- \\
15 \\
125 \\
- \\
- \\
24\end{array}$ & $\begin{array}{r}1,045 \\
373 \\
169 \\
51 \\
44 \\
77 \\
168 \\
93 \\
27\end{array}$ & $\begin{array}{r}1,839 \\
642 \\
482 \\
159 \\
195 \\
432 \\
339 \\
136 \\
55\end{array}$ & $\begin{array}{r}34,004 \\
12,377 \\
4,130 \\
1,960 \\
1,712 \\
2,955 \\
6,629 \\
3,300 \\
941\end{array}$ & $\begin{array}{r}43,770 \\
14,986 \\
10,462 \\
1,790 \\
1,569 \\
5,060 \\
6,072 \\
3,067 \\
764\end{array}$ & $\begin{array}{r}34 \\
34 \\
N \\
N \\
N \\
- \\
- \\
-\end{array}$ & $\begin{array}{r}116 \\
113 \\
0 \\
0 \\
0 \\
1 \\
0 \\
1 \\
0\end{array}$ & $\begin{array}{r}452 \\
448 \\
0 \\
0 \\
0 \\
4 \\
2 \\
3 \\
2\end{array}$ & $\begin{array}{r}4,118 \\
4,051 \\
\mathrm{~N} \\
\mathrm{~N} \\
\mathrm{~N} \\
21 \\
9 \\
35 \\
2\end{array}$ & $\begin{array}{r}1,849 \\
1,777 \\
\mathrm{~N} \\
\mathrm{~N} \\
\mathrm{~N} \\
46 \\
13 \\
10 \\
3\end{array}$ & $\begin{array}{r}27 \\
2 \\
7 \\
4 \\
8 \\
- \\
2 \\
4\end{array}$ & $\begin{array}{l}2 \\
0 \\
1 \\
0 \\
0 \\
0 \\
0 \\
0 \\
0\end{array}$ & $\begin{array}{r}34 \\
2 \\
6 \\
2 \\
26 \\
1 \\
3 \\
3 \\
11\end{array}$ & $\begin{array}{r}202 \\
17 \\
33 \\
16 \\
82 \\
3 \\
12 \\
10 \\
29\end{array}$ & $\begin{array}{r}101 \\
9 \\
32 \\
13 \\
14 \\
11 \\
9 \\
11 \\
2\end{array}$ \\
\hline $\begin{array}{l}\text { Pacific } \\
\text { Alaska } \\
\text { California } \\
\text { Hawaii } \\
\text { Oregon } \$ \\
\text { Washington }\end{array}$ & $\begin{array}{r}1,303 \\
54 \\
842 \\
- \\
178 \\
229\end{array}$ & $\begin{array}{r}3,273 \\
85 \\
2,559 \\
103 \\
174 \\
350\end{array}$ & $\begin{array}{r}5,079 \\
152 \\
4,231 \\
135 \\
315 \\
604\end{array}$ & $\begin{array}{r}114,758 \\
2,897 \\
90,318 \\
3,337 \\
6,083 \\
12,123\end{array}$ & $\begin{array}{r}114,516 \\
2,866 \\
89,024 \\
3,770 \\
6,043 \\
12,813\end{array}$ & $\begin{array}{r}23 \\
23 \\
N \\
N \\
N\end{array}$ & $\begin{array}{r}41 \\
0 \\
41 \\
0 \\
0 \\
0\end{array}$ & $\begin{array}{r}1,179 \\
0 \\
1,179 \\
0 \\
0 \\
0\end{array}$ & $\begin{array}{r}1,686 \\
1,686 \\
N \\
N \\
N\end{array}$ & $\begin{array}{r}999 \\
- \\
999 \\
N \\
N \\
N\end{array}$ & $\begin{array}{l}\frac{1}{-} \\
\frac{1}{-}\end{array}$ & $\begin{array}{l}2 \\
0 \\
0 \\
0 \\
1 \\
0\end{array}$ & $\begin{array}{r}52 \\
2 \\
14 \\
1 \\
6 \\
38\end{array}$ & $\begin{array}{r}51 \\
4 \\
-3 \\
44 \\
\end{array}$ & $\begin{array}{r}240 \\
1 \\
138 \\
1 \\
57 \\
43\end{array}$ \\
\hline $\begin{array}{l}\text { American Samoa } \\
\text { C.N.M.I. } \\
\text { Guam } \\
\text { Puerto Rico } \\
\text { U.S. Virgin Islands }\end{array}$ & $\begin{array}{l}U \\
\frac{U}{-} \\
-\end{array}$ & $\begin{array}{r}0 \\
0 \\
18 \\
77 \\
5\end{array}$ & $\begin{array}{r}46 \\
0 \\
37 \\
161 \\
16\end{array}$ & $\begin{array}{r}U \\
\frac{U}{2,945} \\
178\end{array}$ & $\begin{array}{r}U \\
U \\
569 \\
2,892 \\
189\end{array}$ & $\frac{U}{U}$ & $\begin{array}{l}0 \\
0 \\
0 \\
0 \\
0\end{array}$ & $\begin{array}{l}0 \\
0 \\
0 \\
0 \\
0\end{array}$ & $\frac{U}{U}$ & $\frac{U}{U}$ & $\frac{U}{U}$ & $\begin{array}{l}0 \\
0 \\
0 \\
0 \\
0\end{array}$ & $\begin{array}{l}0 \\
0 \\
0 \\
0 \\
0\end{array}$ & $\frac{U}{U}$ & $\frac{U}{\mathrm{U}}$ \\
\hline
\end{tabular}

C.N.M.I.: Commonwealth of Northern Mariana Islands.

U: Unavailable. - No reported cases. N: Not notifiable.

Cum: Cumulative year-to-date counts.

Med: Median.

Max: Maximum.

.

Chlamydia refers to genital infections caused by Chlamydia trachomatis.

$\S$ Contains data reported through the National Electronic Disease Surveillance System (NEDSS). 
TABLE II. (Continued) Provisional cases of selected notifiable diseases, United States, weeks ending September 9, 2006, and September 10, 2005 (36th Week)*

\begin{tabular}{|c|c|c|c|c|c|c|c|c|c|c|c|c|c|c|c|}
\hline \multirow[b]{3}{*}{ Reporting area } & \multicolumn{5}{|c|}{ Giardiasis } & \multicolumn{5}{|c|}{ Gonorrhea } & \multicolumn{5}{|c|}{$\begin{array}{c}\text { Haemophilus influenzae, invasive } \\
\text { All ages, all serotypes }\end{array}$} \\
\hline & \multirow{2}{*}{$\begin{array}{c}\text { Current } \\
\text { week }\end{array}$} & \multicolumn{2}{|c|}{$\begin{array}{l}\text { Previous } \\
52 \text { weeks }\end{array}$} & \multirow{2}{*}{$\begin{array}{l}\text { Cum } \\
2006\end{array}$} & \multirow{2}{*}{$\begin{array}{l}\text { Cum } \\
2005\end{array}$} & \multirow{2}{*}{$\begin{array}{c}\text { Current } \\
\text { week }\end{array}$} & \multicolumn{2}{|c|}{$\begin{array}{l}\text { Previous } \\
52 \text { weeks }\end{array}$} & \multirow{2}{*}{$\begin{array}{l}\text { Cum } \\
2006\end{array}$} & \multirow{2}{*}{$\begin{array}{l}\text { Cum } \\
2005\end{array}$} & \multirow{2}{*}{$\begin{array}{c}\text { Current } \\
\text { week }\end{array}$} & \multicolumn{2}{|c|}{$\begin{array}{l}\text { Previous } \\
52 \text { weeks }\end{array}$} & \multirow{2}{*}{$\begin{array}{l}\text { Cum } \\
2006\end{array}$} & \multirow{2}{*}{$\begin{array}{l}\text { Cum } \\
2005 \\
\end{array}$} \\
\hline & & Med & Max & & & & Med & Max & & & & Med & $\operatorname{Max}$ & & \\
\hline United States & 224 & 317 & 1,029 & 10,429 & 12,441 & 3,361 & 6,488 & 14,136 & 221,092 & 225,307 & 17 & 38 & 142 & 1,418 & 1,619 \\
\hline $\begin{array}{l}\text { New England } \\
\text { Connecticut } \\
\text { Maine }^{\dagger} \\
\text { Massachusetts } \\
\text { New Hampshire } \\
\text { Rhode Island } \\
\text { Vermont }^{\dagger}\end{array}$ & $\begin{array}{l}\frac{17}{4} \\
2 \\
\frac{5}{5} \\
6\end{array}$ & $\begin{array}{r}25 \\
0 \\
2 \\
10 \\
0 \\
0 \\
3\end{array}$ & $\begin{array}{r}75 \\
37 \\
13 \\
29 \\
9 \\
25 \\
9\end{array}$ & $\begin{array}{r}848 \\
184 \\
106 \\
357 \\
22 \\
72 \\
107\end{array}$ & $\begin{array}{r}1,119 \\
242 \\
144 \\
501 \\
43 \\
70 \\
119\end{array}$ & $\begin{array}{r}55 \\
8 \\
34 \\
4 \\
8 \\
1\end{array}$ & $\begin{array}{r}106 \\
40 \\
2 \\
47 \\
4 \\
8 \\
1\end{array}$ & $\begin{array}{r}288 \\
241 \\
6 \\
86 \\
9 \\
19 \\
3\end{array}$ & $\begin{array}{r}3,738 \\
1,444 \\
86 \\
1,691 \\
140 \\
331 \\
46\end{array}$ & $\begin{array}{r}4,119 \\
1,806 \\
94 \\
1,759 \\
113 \\
309 \\
38\end{array}$ & $\begin{array}{l}2 \\
1 \\
1 \\
- \\
-\end{array}$ & $\begin{array}{l}3 \\
0 \\
0 \\
1 \\
0 \\
0 \\
0\end{array}$ & $\begin{array}{r}19 \\
9 \\
4 \\
7 \\
2 \\
7 \\
2\end{array}$ & $\begin{array}{r}123 \\
37 \\
16 \\
52 \\
6 \\
4 \\
8\end{array}$ & $\begin{array}{r}124 \\
38 \\
8 \\
61 \\
6 \\
7 \\
4\end{array}$ \\
\hline $\begin{array}{l}\text { Mid. Atlantic } \\
\text { New Jersey } \\
\text { New York (Upstate) } \\
\text { New York City } \\
\text { Pennsylvania }\end{array}$ & $\frac{40}{\frac{30}{10}}$ & $\begin{array}{r}53 \\
7 \\
24 \\
10 \\
15\end{array}$ & $\begin{array}{r}254 \\
17 \\
227 \\
32 \\
29\end{array}$ & $\begin{array}{r}1,805 \\
206 \\
774 \\
334 \\
491\end{array}$ & $\begin{array}{r}2,228 \\
301 \\
746 \\
602 \\
579\end{array}$ & $\begin{array}{r}313 \\
62 \\
125 \\
-\frac{1}{126}\end{array}$ & $\begin{array}{l}597 \\
103 \\
123 \\
161 \\
217\end{array}$ & $\begin{array}{r}1,014 \\
150 \\
455 \\
357 \\
393\end{array}$ & $\begin{array}{r}20,211 \\
3,204 \\
4,203 \\
5,217 \\
7,587\end{array}$ & $\begin{array}{r}22,911 \\
3,911 \\
4,445 \\
6,969 \\
7,586\end{array}$ & $\frac{2}{-}$ & $\begin{array}{l}7 \\
2 \\
2 \\
1 \\
3\end{array}$ & $\begin{array}{r}30 \\
4 \\
27 \\
4 \\
8\end{array}$ & $\begin{array}{r}279 \\
45 \\
96 \\
30 \\
108\end{array}$ & $\begin{array}{r}305 \\
59 \\
86 \\
57 \\
103\end{array}$ \\
\hline $\begin{array}{l}\text { E.N. Central } \\
\text { Illinois } \\
\text { Indiana } \\
\text { Michigan } \\
\text { Ohio } \\
\text { Wisconsin }\end{array}$ & $\begin{array}{r}27 \\
\mathrm{~N} \\
4 \\
23 \\
-\end{array}$ & $\begin{array}{r}48 \\
9 \\
0 \\
13 \\
16 \\
10\end{array}$ & $\begin{array}{r}110 \\
25 \\
0 \\
24 \\
32 \\
40\end{array}$ & $\begin{array}{r}1,539 \\
271 \\
\mathrm{~N} \\
420 \\
528 \\
320\end{array}$ & $\begin{array}{r}2,229 \\
533 \\
N \\
548 \\
496 \\
652\end{array}$ & $\begin{array}{r}722 \\
206 \\
162 \\
293 \\
30 \\
31\end{array}$ & $\begin{array}{r}1,272 \\
373 \\
163 \\
242 \\
348 \\
127\end{array}$ & $\begin{array}{r}7,047 \\
709 \\
237 \\
5,880 \\
661 \\
172\end{array}$ & $\begin{array}{r}43,363 \\
13,296 \\
6,073 \\
9,016 \\
10,581 \\
4,397\end{array}$ & $\begin{array}{r}44,270 \\
13,543 \\
5,533 \\
7,114 \\
14,150 \\
3,930\end{array}$ & $\begin{array}{l}\frac{1}{1} \\
- \\
-\end{array}$ & $\begin{array}{l}5 \\
1 \\
1 \\
0 \\
1 \\
0\end{array}$ & $\begin{array}{r}14 \\
6 \\
7 \\
3 \\
6 \\
4\end{array}$ & $\begin{array}{r}197 \\
47 \\
52 \\
17 \\
58 \\
23\end{array}$ & $\begin{array}{r}286 \\
95 \\
52 \\
17 \\
90 \\
32\end{array}$ \\
\hline $\begin{array}{l}\text { W.N. Central } \\
\text { lowa } \\
\text { Kansas } \\
\text { Minnesota } \\
\text { Missouri } \\
\text { Nebraska } \\
\text { North Dakota } \\
\text { South Dakota }\end{array}$ & $\begin{array}{l}-8 \\
4 \\
1 \\
-2 \\
1 \\
-\end{array}$ & $\begin{array}{r}30 \\
5 \\
4 \\
2 \\
9 \\
2 \\
0 \\
1\end{array}$ & $\begin{array}{r}260 \\
12 \\
9 \\
238 \\
32 \\
8 \\
7 \\
7\end{array}$ & $\begin{array}{r}1,227 \\
180 \\
139 \\
477 \\
299 \\
73 \\
11 \\
48\end{array}$ & $\begin{array}{r}1,352 \\
188 \\
134 \\
559 \\
298 \\
84 \\
8 \\
81\end{array}$ & $\begin{array}{r}250 \\
15 \\
57 \\
-140 \\
32 \\
3 \\
3\end{array}$ & $\begin{array}{r}361 \\
33 \\
47 \\
62 \\
190 \\
22 \\
2 \\
6\end{array}$ & $\begin{array}{r}436 \\
46 \\
124 \\
105 \\
251 \\
56 \\
7 \\
13\end{array}$ & $\begin{array}{r}12,640 \\
1,152 \\
1,480 \\
1,808 \\
6,934 \\
936 \\
69 \\
261\end{array}$ & $\begin{array}{r}12,919 \\
1,097 \\
1,813 \\
2,380 \\
6,498 \\
813 \\
64 \\
254\end{array}$ & $\begin{array}{l}2 \\
- \\
2 \\
- \\
-\end{array}$ & $\begin{array}{l}2 \\
0 \\
0 \\
0 \\
0 \\
0 \\
0 \\
0\end{array}$ & $\begin{array}{r}15 \\
1 \\
3 \\
9 \\
6 \\
2 \\
3 \\
0\end{array}$ & $\begin{array}{r}93 \\
1 \\
13 \\
49 \\
21 \\
5 \\
4 \\
-\end{array}$ & $\begin{array}{r}81 \\
9 \\
36 \\
25 \\
10 \\
1 \\
-\end{array}$ \\
\hline $\begin{array}{l}\text { S. Atlantic } \\
\text { Delaware } \\
\text { District of Columbia } \\
\text { Florida } \\
\text { Georgia } \\
\text { Maryland }^{\dagger} \\
\text { North Carolina } \\
\text { South Carolina }^{\dagger} \\
\text { Virginia }^{\dagger} \\
\text { West Virginia }^{\text {West }}\end{array}$ & $\begin{array}{r}39 \\
- \\
29 \\
6 \\
4 \\
\mathrm{~N} \\
- \\
-\end{array}$ & $\begin{array}{r}49 \\
1 \\
1 \\
18 \\
10 \\
4 \\
0 \\
1 \\
8 \\
0\end{array}$ & $\begin{array}{r}95 \\
4 \\
5 \\
39 \\
26 \\
11 \\
0 \\
7 \\
50 \\
5\end{array}$ & $\begin{array}{r}1,580 \\
26 \\
47 \\
705 \\
304 \\
138 \\
\mathrm{~N} \\
62 \\
281 \\
17\end{array}$ & $\begin{array}{r}1,832 \\
40 \\
35 \\
637 \\
489 \\
136 \\
\mathrm{~N} \\
83 \\
382 \\
30\end{array}$ & $\begin{array}{r}942 \\
16 \\
21 \\
268 \\
14 \\
79 \\
345 \\
73 \\
126 \\
-\end{array}$ & $\begin{array}{r}1,487 \\
26 \\
35 \\
433 \\
300 \\
128 \\
283 \\
128 \\
132 \\
17\end{array}$ & $\begin{array}{r}2,334 \\
44 \\
66 \\
549 \\
1,014 \\
186 \\
766 \\
748 \\
288 \\
42\end{array}$ & $\begin{array}{r}53,956 \\
1,002 \\
1,103 \\
15,715 \\
9,296 \\
4,544 \\
11,735 \\
5,528 \\
4,413 \\
620\end{array}$ & $\begin{array}{r}53,108 \\
563 \\
1,411 \\
13,610 \\
10,005 \\
4,725 \\
10,808 \\
5,702 \\
5,811 \\
473\end{array}$ & $\begin{array}{r}7 \\
-- \\
3 \\
1 \\
2 \\
- \\
-1 \\
-\end{array}$ & $\begin{array}{r}10 \\
0 \\
0 \\
3 \\
2 \\
1 \\
0 \\
1 \\
1 \\
0\end{array}$ & $\begin{array}{r}26 \\
1 \\
1 \\
9 \\
12 \\
5 \\
9 \\
3 \\
8 \\
4\end{array}$ & $\begin{array}{r}381 \\
1 \\
3 \\
126 \\
73 \\
48 \\
44 \\
25 \\
46 \\
15\end{array}$ & $\begin{array}{r}388 \\
7 \\
94 \\
83 \\
52 \\
63 \\
24 \\
43 \\
22\end{array}$ \\
\hline $\begin{array}{l}\text { E.S. Central } \\
\text { Alabama }^{\dagger} \\
\text { Kentucky } \\
\text { Mississippi } \\
\text { Tennessee }^{\dagger}\end{array}$ & $\begin{array}{r}10 \\
8 \\
\mathrm{~N} \\
2\end{array}$ & $\begin{array}{l}8 \\
4 \\
0 \\
0 \\
4\end{array}$ & $\begin{array}{r}36 \\
25 \\
0 \\
0 \\
12\end{array}$ & $\begin{array}{r}292 \\
146 \\
\mathrm{~N} \\
146\end{array}$ & $\begin{array}{r}285 \\
126 \\
\mathrm{~N} \\
159\end{array}$ & $\begin{array}{r}266 \\
31 \\
19 \\
90 \\
126\end{array}$ & $\begin{array}{r}572 \\
181 \\
55 \\
145 \\
188\end{array}$ & $\begin{array}{l}856 \\
310 \\
132 \\
435 \\
279\end{array}$ & $\begin{array}{r}20,545 \\
6,561 \\
2,191 \\
5,143 \\
6,650\end{array}$ & $\begin{array}{r}18,857 \\
6,125 \\
2,139 \\
4,805 \\
5,788\end{array}$ & $\frac{1}{-}$ & $\begin{array}{l}2 \\
0 \\
0 \\
0 \\
1\end{array}$ & $\begin{array}{l}7 \\
5 \\
1 \\
1 \\
4\end{array}$ & $\begin{array}{r}73 \\
17 \\
3 \\
3 \\
50\end{array}$ & $\begin{array}{l}88 \\
17 \\
10 \\
61\end{array}$ \\
\hline $\begin{array}{l}\text { W.S. Central } \\
\text { Arkansas } \\
\text { Louisiana } \\
\text { Oklahoma } \\
\text { Texas }^{\dagger}\end{array}$ & $\begin{array}{r}10 \\
5 \\
5 \\
\mathrm{~N}\end{array}$ & $\begin{array}{l}6 \\
2 \\
0 \\
2 \\
0\end{array}$ & $\begin{array}{r}31 \\
6 \\
4 \\
24 \\
0\end{array}$ & $\begin{array}{r}173 \\
77 \\
12 \\
84 \\
\mathrm{~N}\end{array}$ & $\begin{array}{r}205 \\
59 \\
38 \\
108 \\
\mathrm{~N}\end{array}$ & $\begin{array}{r}434 \\
87 \\
3 \\
74 \\
270\end{array}$ & $\begin{array}{r}856 \\
78 \\
158 \\
80 \\
548\end{array}$ & $\begin{array}{r}1,430 \\
186 \\
354 \\
764 \\
760\end{array}$ & $\begin{array}{r}31,689 \\
2,735 \\
5,907 \\
3,018 \\
20,029\end{array}$ & $\begin{array}{r}31,759 \\
3,088 \\
7,141 \\
3,150 \\
18,380\end{array}$ & $\begin{array}{l}- \\
- \\
-\end{array}$ & $\begin{array}{l}1 \\
0 \\
0 \\
1 \\
0\end{array}$ & $\begin{array}{r}15 \\
2 \\
2 \\
14 \\
2\end{array}$ & $\begin{array}{r}45 \\
7 \\
2 \\
34 \\
2\end{array}$ & $\begin{array}{r}92 \\
7 \\
32 \\
49 \\
4\end{array}$ \\
\hline $\begin{array}{l}\text { Mountain } \\
\text { Arizona } \\
\text { Colorado } \\
\text { Idaho }^{\dagger} \\
\text { Montana } \\
\text { Nevada }^{\dagger} \\
\text { New Mexico }{ }^{\dagger} \\
\text { Utah } \\
\text { Wyoming }\end{array}$ & $\begin{array}{r}41 \\
5 \\
14 \\
1 \\
2 \\
- \\
17 \\
2\end{array}$ & $\begin{array}{r}26 \\
3 \\
8 \\
3 \\
2 \\
1 \\
1 \\
7 \\
1\end{array}$ & $\begin{array}{r}54 \\
36 \\
33 \\
11 \\
11 \\
6 \\
6 \\
19 \\
3\end{array}$ & $\begin{array}{r}960 \\
99 \\
289 \\
114 \\
65 \\
38 \\
39 \\
293 \\
23\end{array}$ & $\begin{array}{r}973 \\
97 \\
342 \\
96 \\
47 \\
72 \\
54 \\
248 \\
17\end{array}$ & $\begin{array}{l}86 \\
27 \\
20 \\
- \\
-37 \\
- \\
-\end{array}$ & $\begin{array}{r}217 \\
86 \\
40 \\
2 \\
3 \\
24 \\
29 \\
17 \\
2\end{array}$ & $\begin{array}{r}552 \\
201 \\
90 \\
10 \\
20 \\
194 \\
64 \\
24 \\
6\end{array}$ & $\begin{array}{r}7,334 \\
3,013 \\
1,247 \\
112 \\
138 \\
985 \\
1,199 \\
556 \\
84\end{array}$ & $\begin{array}{r}9,435 \\
3,407 \\
2,213 \\
75 \\
100 \\
2,021 \\
1,104 \\
466 \\
49\end{array}$ & $\begin{array}{l}1 \\
1 \\
- \\
- \\
- \\
- \\
-\end{array}$ & $\begin{array}{l}4 \\
1 \\
1 \\
0 \\
0 \\
0 \\
0 \\
0 \\
0\end{array}$ & $\begin{array}{l}8 \\
7 \\
4 \\
1 \\
0 \\
1 \\
4 \\
4 \\
2\end{array}$ & $\begin{array}{r}145 \\
71 \\
37 \\
3 \\
- \\
18 \\
14 \\
2\end{array}$ & $\begin{array}{r}162 \\
82 \\
35 \\
4 \\
-13 \\
17 \\
7 \\
4\end{array}$ \\
\hline $\begin{array}{l}\text { Pacific } \\
\text { Alaska } \\
\text { California } \\
\text { Hawaii } \\
\text { Oregon }^{\dagger} \\
\text { Washington }^{\dagger}\end{array}$ & $\begin{array}{r}32 \\
3 \\
25 \\
- \\
-4 \\
-\end{array}$ & $\begin{array}{r}59 \\
1 \\
43 \\
1 \\
7 \\
6\end{array}$ & $\begin{array}{r}202 \\
6 \\
105 \\
3 \\
16 \\
90\end{array}$ & $\begin{array}{r}2,005 \\
42 \\
1,453 \\
35 \\
268 \\
207\end{array}$ & $\begin{array}{r}2,218 \\
74 \\
1,577 \\
46 \\
294 \\
227\end{array}$ & $\begin{array}{r}293 \\
6 \\
203 \\
-31 \\
53\end{array}$ & $\begin{array}{r}807 \\
11 \\
653 \\
18 \\
28 \\
74\end{array}$ & $\begin{array}{r}960 \\
23 \\
827 \\
29 \\
58 \\
142\end{array}$ & $\begin{array}{r}27,616 \\
387 \\
22,768 \\
600 \\
929 \\
2,932\end{array}$ & $\begin{array}{r}27,929 \\
399 \\
23,250 \\
711 \\
1,062 \\
2,507\end{array}$ & $\frac{1}{-}$ & $\begin{array}{l}2 \\
0 \\
0 \\
0 \\
1 \\
0\end{array}$ & $\begin{array}{r}20 \\
19 \\
9 \\
1 \\
6 \\
4\end{array}$ & $\begin{array}{r}82 \\
8 \\
19 \\
13 \\
40 \\
2\end{array}$ & $\begin{array}{r}93 \\
6 \\
43 \\
8 \\
36 \\
\end{array}$ \\
\hline $\begin{array}{l}\text { American Samoa } \\
\text { C.N.M.I. } \\
\text { Guam } \\
\text { Puerto Rico } \\
\text { U.S. Virgin Islands }\end{array}$ & $\begin{array}{l}U \\
\frac{U}{9} \\
-\end{array}$ & $\begin{array}{l}0 \\
0 \\
0 \\
2 \\
0\end{array}$ & $\begin{array}{r}0 \\
0 \\
0 \\
20 \\
0\end{array}$ & $\begin{array}{l}U \\
\frac{U}{45} \\
\end{array}$ & $\begin{array}{r}U \\
U \\
11 \\
172 \\
-\end{array}$ & $\begin{array}{l}U \\
U \\
- \\
-\end{array}$ & $\begin{array}{l}0 \\
0 \\
1 \\
5 \\
0\end{array}$ & $\begin{array}{r}2 \\
0 \\
15 \\
16 \\
5\end{array}$ & $\begin{array}{r}U \\
\frac{U}{188} \\
30\end{array}$ & $\begin{array}{r}U \\
U \\
71 \\
266 \\
45\end{array}$ & $\begin{array}{l}U \\
U \\
- \\
-\end{array}$ & $\begin{array}{l}0 \\
0 \\
0 \\
0 \\
0\end{array}$ & $\begin{array}{l}0 \\
0 \\
2 \\
1 \\
0\end{array}$ & $\begin{array}{l}U \\
U \\
- \\
-\end{array}$ & $\begin{array}{l}U \\
U \\
6 \\
3 \\
-\end{array}$ \\
\hline
\end{tabular}

C.N.M.I.: Commonwealth of Northern Mariana Islands.

$\mathrm{U}$ : Unavailable. - No reported cases. N: Not notifiable.

* Incidence data for reporting years 2005 and 2006 are provisional.

Cum: Cumulative year-to-date counts.

Med: Median

Max: Maximum.

${ }^{\dagger}$ Contains data reported through the National Electronic Disease Surveillance System (NEDSS). 
TABLE II. (Continued) Provisional cases of selected notifiable diseases, United States, weeks ending September 9, 2006, and September 10, 2005 (36th Week)

\begin{tabular}{|c|c|c|c|c|c|c|c|c|c|c|c|c|c|c|c|}
\hline \multirow[b]{4}{*}{ Reporting area } & \multicolumn{10}{|c|}{ Hepatitis (viral, acute), by type } & \multirow{2}{*}{\multicolumn{5}{|c|}{ Legionellosis }} \\
\hline & \multicolumn{5}{|c|}{$\mathbf{A}$} & \multicolumn{5}{|c|}{ B } & & & & & \\
\hline & \multirow{2}{*}{$\begin{array}{c}\text { Current } \\
\text { week }\end{array}$} & \multicolumn{2}{|c|}{$\begin{array}{l}\text { Previous } \\
52 \text { weeks }\end{array}$} & \multirow{2}{*}{$\begin{array}{l}\text { Cum } \\
2006\end{array}$} & \multirow{2}{*}{$\begin{array}{l}\text { Cum } \\
2005\end{array}$} & \multirow{2}{*}{$\begin{array}{c}\text { Current } \\
\text { week }\end{array}$} & \multicolumn{2}{|c|}{$\begin{array}{c}\text { Previous } \\
52 \text { weeks } \\
\end{array}$} & \multirow{2}{*}{$\begin{array}{l}\text { Cum } \\
2006\end{array}$} & \multirow{2}{*}{$\begin{array}{l}\text { Cum } \\
2005\end{array}$} & \multirow{2}{*}{$\begin{array}{c}\text { Current } \\
\text { week }\end{array}$} & \multicolumn{2}{|c|}{$\begin{array}{l}\text { Previous } \\
52 \text { weeks }\end{array}$} & \multirow{2}{*}{$\begin{array}{l}\text { Cum } \\
2006\end{array}$} & \multirow{2}{*}{$\begin{array}{l}\text { Cum } \\
2005 \\
\end{array}$} \\
\hline & & Med & $\operatorname{Max}$ & & & & Med & $\operatorname{Max}$ & & & & Med & Max & & \\
\hline United States & 20 & 72 & 245 & 2,202 & 2,748 & 22 & 83 & 597 & 2,642 & 3,593 & 29 & 42 & 127 & 1,348 & 1,314 \\
\hline $\begin{array}{l}\text { New England } \\
\text { Connecticut } \\
\text { Maine }^{\dagger} \\
\text { Massachusetts } \\
\text { New Hampshire } \\
\text { Rhode Island } \\
\text { Vermont }^{\dagger}\end{array}$ & $\begin{array}{l}1 \\
1 \\
- \\
- \\
-\end{array}$ & $\begin{array}{l}4 \\
1 \\
0 \\
2 \\
0 \\
0 \\
0\end{array}$ & $\begin{array}{r}20 \\
3 \\
2 \\
13 \\
16 \\
4 \\
2\end{array}$ & $\begin{array}{r}136 \\
30 \\
6 \\
51 \\
34 \\
8 \\
7\end{array}$ & $\begin{array}{r}326 \\
37 \\
2 \\
202 \\
70 \\
10 \\
5\end{array}$ & $\begin{array}{l}- \\
- \\
- \\
-\end{array}$ & $\begin{array}{l}1 \\
0 \\
0 \\
0 \\
0 \\
0 \\
0\end{array}$ & $\begin{array}{l}9 \\
3 \\
2 \\
5 \\
2 \\
4 \\
1\end{array}$ & $\begin{array}{r}46 \\
13 \\
14 \\
11 \\
8 \\
-\end{array}$ & $\begin{array}{r}99 \\
34 \\
10 \\
32 \\
19 \\
1 \\
3\end{array}$ & $\begin{array}{l}- \\
- \\
- \\
-\end{array}$ & $\begin{array}{l}2 \\
0 \\
0 \\
1 \\
0 \\
0 \\
0\end{array}$ & $\begin{array}{r}12 \\
8 \\
2 \\
6 \\
1 \\
10 \\
3\end{array}$ & $\begin{array}{r}68 \\
19 \\
6 \\
27 \\
1 \\
12 \\
3\end{array}$ & $\begin{array}{r}86 \\
22 \\
4 \\
48 \\
38 \\
6 \\
12 \\
4\end{array}$ \\
\hline $\begin{array}{l}\text { Mid. Atlantic } \\
\text { New Jersey } \\
\text { New York (Upstate) } \\
\text { New York City } \\
\text { Pennsylvania }\end{array}$ & $\begin{array}{r}\frac{4}{4} \\
- \\
-\end{array}$ & $\begin{array}{l}7 \\
2 \\
1 \\
2 \\
1\end{array}$ & $\begin{array}{r}24 \\
9 \\
14 \\
10 \\
5\end{array}$ & $\begin{array}{r}215 \\
54 \\
60 \\
61 \\
40\end{array}$ & $\begin{array}{r}452 \\
93 \\
66 \\
216 \\
77\end{array}$ & $\frac{1}{-}$ & $\begin{array}{l}8 \\
2 \\
1 \\
1 \\
3\end{array}$ & $\begin{array}{r}55 \\
10 \\
43 \\
5 \\
9\end{array}$ & $\begin{array}{r}267 \\
73 \\
46 \\
41 \\
107\end{array}$ & $\begin{array}{r}472 \\
180 \\
36 \\
98 \\
158\end{array}$ & $\frac{12}{\frac{9}{3}}$ & $\begin{array}{r}13 \\
1 \\
5 \\
1 \\
5\end{array}$ & $\begin{array}{r}42 \\
10 \\
29 \\
9 \\
17\end{array}$ & $\begin{array}{r}450 \\
60 \\
181 \\
25 \\
184\end{array}$ & $\begin{array}{r}443 \\
77 \\
111 \\
73 \\
182\end{array}$ \\
\hline $\begin{array}{l}\text { E.N. Central } \\
\text { Illinois } \\
\text { Indiana } \\
\text { Michigan } \\
\text { Ohio } \\
\text { Wisconsin }\end{array}$ & $\begin{array}{l}\frac{1}{1} \\
- \\
-\end{array}$ & $\begin{array}{l}6 \\
1 \\
0 \\
1 \\
1 \\
1\end{array}$ & $\begin{array}{r}13 \\
11 \\
5 \\
8 \\
4 \\
5\end{array}$ & $\begin{array}{r}176 \\
40 \\
20 \\
59 \\
41 \\
16\end{array}$ & $\begin{array}{r}247 \\
90 \\
12 \\
78 \\
36 \\
31\end{array}$ & $\begin{array}{l}\frac{5}{4} \\
\frac{1}{-}\end{array}$ & $\begin{array}{l}7 \\
1 \\
0 \\
3 \\
2 \\
0\end{array}$ & $\begin{array}{r}24 \\
6 \\
17 \\
7 \\
10 \\
4\end{array}$ & $\begin{array}{r}247 \\
18 \\
39 \\
95 \\
89 \\
6\end{array}$ & $\begin{array}{r}401 \\
115 \\
28 \\
127 \\
98 \\
33\end{array}$ & $\begin{array}{l}\frac{5}{-} \\
\frac{5}{-}\end{array}$ & $\begin{array}{l}8 \\
1 \\
0 \\
2 \\
4 \\
0\end{array}$ & $\begin{array}{r}25 \\
4 \\
6 \\
6 \\
19 \\
5\end{array}$ & $\begin{array}{r}280 \\
21 \\
20 \\
71 \\
149 \\
19\end{array}$ & $\begin{array}{r}254 \\
41 \\
14 \\
74 \\
102 \\
23\end{array}$ \\
\hline $\begin{array}{l}\text { W.N. Central } \\
\text { lowa } \\
\text { Kansas } \\
\text { Minnesota } \\
\text { Missouri } \\
\text { Nebraska }{ }^{\dagger} \\
\text { North Dakota } \\
\text { South Dakota }\end{array}$ & $\begin{array}{l}- \\
- \\
- \\
- \\
-\end{array}$ & $\begin{array}{l}2 \\
0 \\
0 \\
0 \\
1 \\
0 \\
0 \\
0\end{array}$ & $\begin{array}{r}30 \\
2 \\
5 \\
29 \\
3 \\
3 \\
2 \\
3\end{array}$ & $\begin{array}{r}88 \\
8 \\
23 \\
9 \\
29 \\
12 \\
-7\end{array}$ & $\begin{array}{r}64 \\
18 \\
12 \\
3 \\
25 \\
6 \\
\end{array}$ & $\begin{array}{l}2 \\
- \\
-2 \\
- \\
-\end{array}$ & $\begin{array}{l}4 \\
0 \\
0 \\
0 \\
2 \\
0 \\
0 \\
0\end{array}$ & $\begin{array}{r}22 \\
3 \\
2 \\
13 \\
7 \\
1 \\
0 \\
1\end{array}$ & $\begin{array}{r}107 \\
10 \\
8 \\
16 \\
64 \\
9 \\
-\end{array}$ & $\begin{array}{r}183 \\
19 \\
22 \\
20 \\
97 \\
20 \\
5\end{array}$ & $\begin{array}{l}- \\
- \\
- \\
- \\
- \\
-\end{array}$ & $\begin{array}{l}1 \\
0 \\
0 \\
0 \\
0 \\
0 \\
0 \\
0\end{array}$ & $\begin{array}{r}14 \\
3 \\
2 \\
11 \\
3 \\
2 \\
1 \\
6\end{array}$ & $\begin{array}{r}47 \\
8 \\
4 \\
11 \\
15 \\
5 \\
4\end{array}$ & $\begin{array}{r}57 \\
4 \\
2 \\
16 \\
21 \\
2 \\
2 \\
10\end{array}$ \\
\hline $\begin{array}{l}\text { S. Atlantic } \\
\text { Delaware } \\
\text { District of Columbia } \\
\text { Florida } \\
\text { Georgia } \\
\text { Maryland }^{\dagger} \\
\text { North Carolina } \text { South Carolina }^{\dagger} \\
\text { Virginia }^{\dagger} \\
\text { West Virginia }^{\text {West }}\end{array}$ & $\begin{array}{l}5 \\
- \\
2 \\
1 \\
2 \\
- \\
-\end{array}$ & $\begin{array}{r}11 \\
0 \\
0 \\
4 \\
1 \\
1 \\
0 \\
0 \\
1 \\
0\end{array}$ & $\begin{array}{r}34 \\
2 \\
2 \\
18 \\
7 \\
6 \\
20 \\
3 \\
11 \\
3\end{array}$ & $\begin{array}{r}361 \\
10 \\
5 \\
141 \\
50 \\
43 \\
61 \\
13 \\
34 \\
4\end{array}$ & $\begin{array}{r}472 \\
5 \\
2 \\
183 \\
95 \\
46 \\
57 \\
27 \\
54 \\
3\end{array}$ & $\begin{array}{r}9 \\
-\frac{6}{6} \\
1 \\
-1 \\
-1 \\
-\end{array}$ & $\begin{array}{r}23 \\
1 \\
0 \\
8 \\
3 \\
3 \\
0 \\
2 \\
1 \\
0\end{array}$ & $\begin{array}{r}66 \\
4 \\
2 \\
2 \\
19 \\
7 \\
10 \\
23 \\
7 \\
18 \\
18\end{array}$ & $\begin{array}{r}797 \\
32 \\
5 \\
287 \\
117 \\
116 \\
106 \\
52 \\
39 \\
43\end{array}$ & $\begin{array}{r}988 \\
22 \\
10 \\
339 \\
155 \\
107 \\
112 \\
111 \\
105 \\
27\end{array}$ & $\begin{array}{r}9 \\
-- \\
4 \\
1 \\
1 \\
3 \\
- \\
-\end{array}$ & $\begin{array}{l}8 \\
0 \\
0 \\
3 \\
0 \\
1 \\
0 \\
0 \\
1 \\
0\end{array}$ & $\begin{array}{r}19 \\
2 \\
5 \\
9 \\
4 \\
5 \\
5 \\
1 \\
7 \\
3\end{array}$ & $\begin{array}{r}276 \\
8 \\
14 \\
115 \\
12 \\
50 \\
26 \\
2 \\
42 \\
7\end{array}$ & $\begin{array}{r}273 \\
13 \\
8 \\
72 \\
22 \\
82 \\
21 \\
11 \\
32 \\
12\end{array}$ \\
\hline $\begin{array}{l}\text { E.S. Central } \\
\text { Alabama }^{\dagger} \\
\text { Kentucky } \\
\text { Mississippi } \\
\text { Tennessee }^{\dagger}\end{array}$ & $\begin{array}{l}- \\
- \\
-\end{array}$ & $\begin{array}{l}2 \\
0 \\
0 \\
0 \\
1\end{array}$ & $\begin{array}{r}15 \\
9 \\
5 \\
1 \\
6\end{array}$ & $\begin{array}{r}88 \\
10 \\
28 \\
5 \\
45\end{array}$ & $\begin{array}{r}190 \\
26 \\
19 \\
15 \\
130\end{array}$ & $\begin{array}{r}2 \\
1 \\
1 \\
- \\
-\end{array}$ & $\begin{array}{l}6 \\
1 \\
1 \\
0 \\
2\end{array}$ & $\begin{array}{r}12 \\
7 \\
5 \\
3 \\
8\end{array}$ & $\begin{array}{r}223 \\
70 \\
49 \\
10 \\
94\end{array}$ & $\begin{array}{r}258 \\
59 \\
49 \\
41 \\
109\end{array}$ & $\begin{array}{l}- \\
- \\
-\end{array}$ & $\begin{array}{l}1 \\
0 \\
0 \\
0 \\
1\end{array}$ & $\begin{array}{l}9 \\
2 \\
4 \\
1 \\
7\end{array}$ & $\begin{array}{r}55 \\
7 \\
17 \\
1 \\
30\end{array}$ & $\begin{array}{r}56 \\
10 \\
17 \\
3 \\
26\end{array}$ \\
\hline $\begin{array}{l}\text { W.S. Central } \\
\text { Arkansas } \\
\text { Louisiana } \\
\text { Oklahoma } \\
\text { Texas }^{\dagger}\end{array}$ & $\begin{array}{l}- \\
- \\
-\end{array}$ & $\begin{array}{l}5 \\
0 \\
0 \\
0 \\
4\end{array}$ & $\begin{array}{r}77 \\
9 \\
3 \\
2 \\
73\end{array}$ & $\begin{array}{r}120 \\
32 \\
2 \\
4 \\
82\end{array}$ & $\begin{array}{r}302 \\
11 \\
51 \\
4 \\
236\end{array}$ & $\begin{array}{l}- \\
- \\
-\end{array}$ & $\begin{array}{r}14 \\
1 \\
0 \\
0 \\
11\end{array}$ & $\begin{array}{r}315 \\
4 \\
3 \\
17 \\
295\end{array}$ & $\begin{array}{r}441 \\
31 \\
11 \\
26 \\
373\end{array}$ & $\begin{array}{r}391 \\
48 \\
58 \\
31 \\
254\end{array}$ & $\begin{array}{l}- \\
- \\
-\end{array}$ & $\begin{array}{l}1 \\
0 \\
0 \\
0 \\
0\end{array}$ & $\begin{array}{r}32 \\
3 \\
2 \\
3 \\
26\end{array}$ & $\begin{array}{r}38 \\
3 \\
4 \\
1 \\
30\end{array}$ & $\begin{array}{r}26 \\
5 \\
1 \\
3 \\
17\end{array}$ \\
\hline $\begin{array}{l}\text { Mountain } \\
\text { Arizona } \\
\text { Colorado } \\
\text { Idaho }^{\dagger} \\
\text { Montana } \\
\text { Nevada }^{\dagger} \\
\text { New Mexico } \\
\text { Utah } \\
\text { Wyoming }\end{array}$ & $\begin{array}{l}5 \\
3 \\
1 \\
1 \\
- \\
- \\
- \\
-\end{array}$ & $\begin{array}{l}5 \\
2 \\
1 \\
0 \\
0 \\
0 \\
0 \\
0 \\
0\end{array}$ & $\begin{array}{r}18 \\
16 \\
4 \\
2 \\
3 \\
2 \\
3 \\
2 \\
1\end{array}$ & $\begin{array}{r}182 \\
104 \\
27 \\
9 \\
9 \\
7 \\
12 \\
11 \\
3\end{array}$ & $\begin{array}{r}212 \\
107 \\
28 \\
18 \\
7 \\
16 \\
18 \\
17 \\
1\end{array}$ & $\begin{array}{l}-1 \\
- \\
- \\
- \\
- \\
-\end{array}$ & $\begin{array}{l}5 \\
2 \\
1 \\
0 \\
0 \\
0 \\
0 \\
0 \\
0\end{array}$ & $\begin{array}{r}39 \\
23 \\
5 \\
2 \\
7 \\
4 \\
3 \\
5 \\
1\end{array}$ & $\begin{array}{r}142 \\
55 \\
24 \\
10 \\
-14 \\
15 \\
24 \\
-\end{array}$ & $\begin{array}{r}372 \\
236 \\
39 \\
9 \\
3 \\
40 \\
14 \\
29 \\
2\end{array}$ & $\begin{array}{l}2 \\
1 \\
- \\
- \\
- \\
- \\
-\end{array}$ & $\begin{array}{l}2 \\
1 \\
0 \\
0 \\
0 \\
0 \\
0 \\
0 \\
0\end{array}$ & $\begin{array}{l}7 \\
3 \\
2 \\
2 \\
2 \\
1 \\
2 \\
1 \\
1 \\
1 \\
0\end{array}$ & $\begin{array}{r}68 \\
25 \\
7 \\
7 \\
5 \\
3 \\
4 \\
17 \\
-\end{array}$ & $\begin{array}{r}70 \\
15 \\
17 \\
3 \\
5 \\
14 \\
2 \\
10 \\
4\end{array}$ \\
\hline $\begin{array}{l}\text { Pacific } \\
\text { Alaska } \\
\text { California } \\
\text { Hawaii } \\
\text { Oregon }^{\dagger} \\
\text { Washington }^{+}\end{array}$ & $\begin{array}{l}4 \\
\\
- \\
-\end{array}$ & $\begin{array}{r}21 \\
0 \\
18 \\
0 \\
1 \\
1\end{array}$ & $\begin{array}{r}163 \\
1 \\
162 \\
2 \\
5 \\
13\end{array}$ & $\begin{array}{r}836 \\
759 \\
8 \\
36 \\
33\end{array}$ & $\begin{array}{r}483 \\
3 \\
401 \\
20 \\
28 \\
31\end{array}$ & $\begin{array}{l}\frac{2}{2} \\
- \\
-\end{array}$ & $\begin{array}{l}9 \\
0 \\
7 \\
0 \\
1 \\
0\end{array}$ & $\begin{array}{r}61 \\
1 \\
41 \\
1 \\
6 \\
6 \\
18\end{array}$ & $\begin{array}{r}372 \\
3 \\
288 \\
4 \\
46 \\
31\end{array}$ & $\begin{array}{r}429 \\
7 \\
286 \\
6 \\
79 \\
51\end{array}$ & $\begin{array}{l}\frac{1}{1} \\
\frac{1}{N}\end{array}$ & $\begin{array}{l}2 \\
0 \\
2 \\
0 \\
0 \\
0\end{array}$ & $\begin{array}{l}9 \\
1 \\
9 \\
1 \\
0 \\
0\end{array}$ & $\frac{66}{\frac{66}{N}}$ & $\begin{array}{r}49 \\
47 \\
2 \\
N \\
-\end{array}$ \\
\hline $\begin{array}{l}\text { American Samoa } \\
\text { C.N.M.I. } \\
\text { Guam } \\
\text { Puerto Rico } \\
\text { U.S. Virgin Islands }\end{array}$ & $\frac{U}{U}$ & $\begin{array}{l}0 \\
0 \\
0 \\
0 \\
0\end{array}$ & $\begin{array}{l}0 \\
0 \\
0 \\
3 \\
0\end{array}$ & $\frac{U}{U} \frac{U}{19}$ & $\begin{array}{r}1 \\
U \\
2 \\
55 \\
\end{array}$ & $\begin{array}{l}U \\
\frac{U}{1} \\
-\end{array}$ & $\begin{array}{l}0 \\
0 \\
0 \\
1 \\
0\end{array}$ & $\begin{array}{l}0 \\
0 \\
0 \\
8 \\
0\end{array}$ & $\frac{U}{\frac{U}{24}}$ & $\begin{array}{r}- \\
U \\
18 \\
34 \\
-\end{array}$ & $\begin{array}{l}U \\
U \\
- \\
-\end{array}$ & $\begin{array}{l}0 \\
0 \\
0 \\
0 \\
0\end{array}$ & $\begin{array}{l}0 \\
0 \\
0 \\
1 \\
0\end{array}$ & $\begin{array}{l}U \\
\frac{U}{1} \\
-\end{array}$ & $\begin{array}{l}U \\
U \\
- \\
-\end{array}$ \\
\hline
\end{tabular}

C.N.M.I.: Commonwealth of Northern Mariana Islands.

$\mathrm{U}:$ Unavailable. $\quad-$ : No reported cases. N: Not notifiable.

* Incidence data for reporting years 2005 and 2006 are provisional.

Cum: Cumulative year-to-date counts.

Med: Median

Max: Maximum.

${ }^{\dagger}$ Contains data reported through the National Electronic Disease Surveillance System (NEDSS). 
TABLE II. (Continued) Provisional cases of selected notifiable diseases, United States, weeks ending September 9, 2006, and September 10, 2005 (36th Week)*

\begin{tabular}{|c|c|c|c|c|c|c|c|c|c|c|}
\hline \multirow[b]{4}{*}{ Reporting area } & \multicolumn{5}{|c|}{ Lyme disease } & \multicolumn{5}{|c|}{ Malaria } \\
\hline & \multirow{3}{*}{$\begin{array}{c}\text { Current } \\
\text { week }\end{array}$} & \multirow{2}{*}{\multicolumn{2}{|c|}{$\begin{array}{l}\text { Previous } \\
52 \text { weeks }\end{array}$}} & \multirow{3}{*}{$\begin{array}{l}\text { Cum } \\
2006 \\
\end{array}$} & \multirow{3}{*}{$\begin{array}{l}\text { Cum } \\
2005 \\
\end{array}$} & \multirow{3}{*}{$\begin{array}{c}\text { Current } \\
\text { week }\end{array}$} & \multirow{2}{*}{\multicolumn{2}{|c|}{$\begin{array}{l}\text { Previous } \\
52 \text { weeks }\end{array}$}} & \multirow{3}{*}{$\begin{array}{l}\text { Cum } \\
2006 \\
\end{array}$} & \multirow{3}{*}{$\begin{array}{l}\text { Cum } \\
2005 \\
\end{array}$} \\
\hline & & & & & & & & & & \\
\hline & & Med & Max & & & & Med & $\operatorname{Max}$ & & \\
\hline United States & 132 & 248 & 2,153 & 10,918 & 15,907 & 13 & 24 & 125 & 827 & 975 \\
\hline $\begin{array}{l}\text { New England } \\
\text { Connecticut } \\
\text { Maine }^{\dagger} \\
\text { Massachusetts } \\
\text { New Hampshire } \\
\text { Rhode Island } \\
\text { Vermont }^{\dagger}\end{array}$ & $\begin{array}{r}34 \\
20 \\
9 \\
-4 \\
-1\end{array}$ & $\begin{array}{r}37 \\
9 \\
2 \\
2 \\
5 \\
0 \\
1\end{array}$ & $\begin{array}{r}780 \\
753 \\
34 \\
48 \\
50 \\
5 \\
8\end{array}$ & $\begin{array}{r}1,903 \\
1,356 \\
98 \\
33 \\
362 \\
54\end{array}$ & $\begin{array}{r}2,806 \\
391 \\
200 \\
1,997 \\
158 \\
25 \\
35\end{array}$ & $\begin{array}{l}2 \\
1 \\
-1 \\
- \\
-\end{array}$ & $\begin{array}{l}1 \\
0 \\
0 \\
0 \\
0 \\
0 \\
0\end{array}$ & $\begin{array}{r}11 \\
5 \\
1 \\
3 \\
3 \\
8 \\
1\end{array}$ & $\begin{array}{r}42 \\
11 \\
3 \\
19 \\
8 \\
1\end{array}$ & $\begin{array}{r}50 \\
11 \\
4 \\
27 \\
5 \\
2 \\
1\end{array}$ \\
\hline $\begin{array}{l}\text { Mid. Atlantic } \\
\text { New Jersey } \\
\text { New York (Upstate) } \\
\text { New York City } \\
\text { Pennsylvania }\end{array}$ & $\frac{89}{\frac{75}{14}}$ & $\begin{array}{r}155 \\
24 \\
78 \\
1 \\
40\end{array}$ & $\begin{array}{r}1,176 \\
141 \\
1,150 \\
15 \\
213\end{array}$ & $\begin{array}{r}6,311 \\
1,295 \\
2,722 \\
13 \\
2,281\end{array}$ & $\begin{array}{r}9,250 \\
2,964 \\
2,541 \\
310 \\
3,435\end{array}$ & $\begin{array}{l}4 \\
2 \\
1 \\
1\end{array}$ & $\begin{array}{l}5 \\
1 \\
1 \\
2 \\
1\end{array}$ & $\begin{array}{r}13 \\
3 \\
11 \\
8 \\
3\end{array}$ & $\begin{array}{r}150 \\
28 \\
25 \\
70 \\
27\end{array}$ & $\begin{array}{r}266 \\
67 \\
31 \\
142 \\
26\end{array}$ \\
\hline $\begin{array}{l}\text { E.N. Central } \\
\text { Illinois } \\
\text { Indiana } \\
\text { Michigan } \\
\text { Ohio } \\
\text { Wisconsin }\end{array}$ & $\begin{array}{l}- \\
- \\
- \\
-\end{array}$ & $\begin{array}{r}11 \\
0 \\
0 \\
1 \\
1 \\
10\end{array}$ & $\begin{array}{r}102 \\
2 \\
3 \\
6 \\
6 \\
97\end{array}$ & $\begin{array}{r}895 \\
15 \\
34 \\
34 \\
812\end{array}$ & $\begin{array}{r}1,512 \\
116 \\
23 \\
39 \\
41 \\
1,293\end{array}$ & $\begin{array}{l}\frac{1}{-} \\
\frac{1}{-}\end{array}$ & $\begin{array}{l}2 \\
1 \\
0 \\
0 \\
0 \\
0\end{array}$ & $\begin{array}{l}7 \\
4 \\
3 \\
2 \\
3 \\
3\end{array}$ & $\begin{array}{r}81 \\
30 \\
8 \\
15 \\
21 \\
7\end{array}$ & $\begin{array}{r}109 \\
62 \\
3 \\
18 \\
16 \\
10\end{array}$ \\
\hline $\begin{array}{l}\text { W.N. Central } \\
\text { lowa } \\
\text { Kansas } \\
\text { Minnesota } \\
\text { Missouri } \\
\text { Nebraska }{ }^{\dagger} \\
\text { North Dakota } \\
\text { South Dakota }\end{array}$ & $\begin{array}{l}- \\
- \\
- \\
- \\
-\end{array}$ & $\begin{array}{l}8 \\
1 \\
0 \\
6 \\
0 \\
0 \\
0 \\
0\end{array}$ & $\begin{array}{r}91 \\
8 \\
2 \\
88 \\
3 \\
2 \\
3 \\
1\end{array}$ & $\begin{array}{r}319 \\
68 \\
3 \\
231 \\
8 \\
8 \\
1\end{array}$ & $\begin{array}{r}514 \\
80 \\
3 \\
417 \\
11 \\
1 \\
2\end{array}$ & $\begin{array}{l}- \\
- \\
- \\
- \\
-\end{array}$ & $\begin{array}{l}0 \\
0 \\
0 \\
0 \\
0 \\
0 \\
0 \\
0\end{array}$ & $\begin{array}{r}32 \\
1 \\
2 \\
30 \\
2 \\
2 \\
1 \\
1\end{array}$ & $\begin{array}{r}31 \\
1 \\
5 \\
14 \\
5 \\
4 \\
1 \\
1\end{array}$ & $\begin{array}{r}36 \\
6 \\
4 \\
11 \\
14 \\
1 \\
-\end{array}$ \\
\hline $\begin{array}{l}\text { S. Atlantic } \\
\text { Delaware } \\
\text { District of Columbia } \\
\text { Florida } \\
\text { Georgia } \\
\text { Maryland }^{\dagger} \\
\text { North Carolina } \\
\text { South Carolina }^{\dagger} \\
\text { Virginia }^{\dagger} \\
\text { West Virginia }^{\text {Westia }}\end{array}$ & $\begin{array}{l}4 \\
1 \\
-1 \\
-2 \\
- \\
- \\
-\end{array}$ & $\begin{array}{r}30 \\
8 \\
0 \\
1 \\
0 \\
16 \\
0 \\
0 \\
3 \\
0\end{array}$ & $\begin{array}{r}102 \\
27 \\
7 \\
5 \\
1 \\
59 \\
5 \\
3 \\
25 \\
44\end{array}$ & $\begin{array}{r}1,224 \\
360 \\
33 \\
25 \\
2 \\
597 \\
21 \\
7 \\
172 \\
7\end{array}$ & $\begin{array}{r}1,654 \\
532 \\
8 \\
25 \\
5 \\
868 \\
40 \\
14 \\
155 \\
7\end{array}$ & $\begin{array}{l}3 \\
\frac{-}{2} \\
\frac{1}{-} \\
- \\
-\end{array}$ & $\begin{array}{l}7 \\
0 \\
0 \\
1 \\
1 \\
1 \\
0 \\
0 \\
1 \\
0\end{array}$ & $\begin{array}{r}15 \\
1 \\
2 \\
6 \\
6 \\
5 \\
8 \\
2 \\
9 \\
2\end{array}$ & $\begin{array}{r}235 \\
5 \\
3 \\
43 \\
64 \\
51 \\
19 \\
7 \\
41 \\
2\end{array}$ & $\begin{array}{r}212 \\
3 \\
8 \\
35 \\
41 \\
76 \\
22 \\
7 \\
19 \\
1\end{array}$ \\
\hline $\begin{array}{l}\text { E.S. Central } \\
\text { Alabama }^{\dagger} \\
\text { Kentucky } \\
\text { Mississippi } \\
\text { Tennessee }^{\dagger}\end{array}$ & $\frac{1}{-}$ & $\begin{array}{l}0 \\
0 \\
0 \\
0 \\
0\end{array}$ & $\begin{array}{l}4 \\
1 \\
2 \\
0 \\
2\end{array}$ & $\begin{array}{r}16 \\
5 \\
4 \\
7\end{array}$ & $\frac{24}{\frac{3}{21}}$ & $\begin{array}{l}- \\
- \\
-\end{array}$ & $\begin{array}{l}0 \\
0 \\
0 \\
0 \\
0\end{array}$ & $\begin{array}{l}3 \\
2 \\
2 \\
1 \\
2\end{array}$ & $\begin{array}{r}19 \\
8 \\
3 \\
3 \\
5\end{array}$ & $\begin{array}{r}20 \\
4 \\
5 \\
11\end{array}$ \\
\hline $\begin{array}{l}\text { W.S. Central } \\
\text { Arkansas } \\
\text { Louisiana } \\
\text { Oklahoma } \\
\text { Texas }^{\dagger}\end{array}$ & $\begin{array}{l}- \\
- \\
-\end{array}$ & $\begin{array}{l}0 \\
0 \\
0 \\
0 \\
0\end{array}$ & $\begin{array}{l}3 \\
1 \\
0 \\
0 \\
3\end{array}$ & $\frac{10}{-}$ & $\begin{array}{r}62 \\
4 \\
3 \\
55\end{array}$ & $\begin{array}{l}- \\
- \\
-\end{array}$ & $\begin{array}{l}2 \\
0 \\
0 \\
0 \\
1\end{array}$ & $\begin{array}{r}31 \\
1 \\
1 \\
6 \\
29\end{array}$ & $\begin{array}{r}51 \\
1 \\
1 \\
7 \\
42\end{array}$ & $\begin{array}{r}88 \\
5 \\
2 \\
3 \\
78\end{array}$ \\
\hline $\begin{array}{l}\text { Mountain } \\
\text { Arizona } \\
\text { Colorado } \\
\text { Idaho }^{\dagger} \\
\text { Montana } \text { Nevada }^{\dagger} \\
\text { New Mexico } \\
\text { Utah } \\
\text { Wyoming }\end{array}$ & $\begin{array}{l}- \\
- \\
- \\
- \\
- \\
-\end{array}$ & $\begin{array}{l}0 \\
0 \\
0 \\
0 \\
0 \\
0 \\
0 \\
0 \\
0\end{array}$ & $\begin{array}{l}4 \\
4 \\
1 \\
1 \\
0 \\
1 \\
1 \\
1 \\
0\end{array}$ & $\begin{array}{r}16 \\
4 \\
2 \\
2 \\
-1 \\
1 \\
6 \\
-\end{array}$ & $\begin{array}{r}15 \\
3 \\
-2 \\
\\
3 \\
2 \\
2 \\
3\end{array}$ & $\begin{array}{l}- \\
- \\
- \\
- \\
- \\
-\end{array}$ & $\begin{array}{l}1 \\
0 \\
0 \\
0 \\
0 \\
0 \\
0 \\
0 \\
0\end{array}$ & $\begin{array}{l}9 \\
9 \\
2 \\
1 \\
1 \\
1 \\
1 \\
2 \\
1\end{array}$ & $\begin{array}{r}48 \\
17 \\
9 \\
1 \\
2 \\
1 \\
3 \\
15 \\
-\end{array}$ & $\begin{array}{r}37 \\
6 \\
20 \\
- \\
2 \\
3 \\
5 \\
1\end{array}$ \\
\hline $\begin{array}{l}\text { Pacific } \\
\text { Alaska } \\
\text { California } \\
\text { Hawaii } \\
\text { Oregon }^{\dagger} \\
\text { Washington }^{\dagger}\end{array}$ & $\begin{array}{l}4 \\
4 \\
N \\
-\end{array}$ & $\begin{array}{l}4 \\
0 \\
4 \\
0 \\
0 \\
0\end{array}$ & $\begin{array}{r}22 \\
1 \\
21 \\
0 \\
2 \\
3\end{array}$ & $\begin{array}{r}224 \\
2 \\
212 \\
N \\
7 \\
3\end{array}$ & $\begin{array}{r}70 \\
4 \\
42 \\
\mathrm{~N} \\
17 \\
7\end{array}$ & $\begin{array}{l}\frac{3}{3} \\
- \\
-\end{array}$ & $\begin{array}{l}4 \\
0 \\
4 \\
0 \\
0 \\
0\end{array}$ & $\begin{array}{r}13 \\
4 \\
10 \\
2 \\
1 \\
5\end{array}$ & $\begin{array}{r}170 \\
21 \\
118 \\
4 \\
8 \\
8 \\
19\end{array}$ & $\begin{array}{r}157 \\
3 \\
117 \\
14 \\
9 \\
14\end{array}$ \\
\hline $\begin{array}{l}\text { American Samoa } \\
\text { C.N.M.I. } \\
\text { Guam } \\
\text { Puerto Rico } \\
\text { U.S. Virgin Islands }\end{array}$ & $\frac{U}{U} \frac{U}{-}$ & $\begin{array}{l}0 \\
0 \\
0 \\
0 \\
0\end{array}$ & $\begin{array}{l}0 \\
0 \\
0 \\
0 \\
0\end{array}$ & $\begin{array}{l}U \\
\frac{U}{N} \\
\end{array}$ & $\begin{array}{l}U \\
\frac{U}{N} \\
-\end{array}$ & $\begin{array}{l}U \\
U \\
- \\
-\end{array}$ & $\begin{array}{l}0 \\
0 \\
0 \\
0 \\
0\end{array}$ & $\begin{array}{l}0 \\
0 \\
0 \\
1 \\
0\end{array}$ & $\begin{array}{l}U \\
U \\
- \\
\end{array}$ & $\frac{U}{U}$ \\
\hline
\end{tabular}

C.N.M.I: Commonwealth of Northern Mariana Islands.

U: Unavailable - No reported cases. N: Not notifiable.

* Incidence data for reporting years 2005 and 2006 are provisional.

Cum: Cumulative year-to-date counts.

Med: Median.

Max: Maximum

${ }^{\dagger}$ Contains data reported through the National Electronic Disease Surveillance System (NEDSS) 
TABLE II. (Continued) Provisional cases of selected notifiable diseases, United States, weeks ending September 9, 2006, and September 10, 2005 (36th Week)*

\begin{tabular}{|c|c|c|c|c|c|c|c|c|c|c|c|c|c|c|c|}
\hline \multirow[b]{4}{*}{ Reporting area } & \multicolumn{10}{|c|}{ Meningococcal disease, invasive } & \multirow{2}{*}{\multicolumn{5}{|c|}{ Pertussis }} \\
\hline & \multicolumn{5}{|c|}{ All serogroups } & \multicolumn{5}{|c|}{ Serogroup unknown } & & & & & \\
\hline & \multirow{2}{*}{$\begin{array}{c}\text { Current } \\
\text { week }\end{array}$} & \multicolumn{2}{|c|}{$\begin{array}{l}\text { Previous } \\
52 \text { weeks }\end{array}$} & \multirow{2}{*}{$\begin{array}{l}\text { Cum } \\
2006 \\
\end{array}$} & \multirow{2}{*}{$\begin{array}{l}\text { Cum } \\
2005 \\
\end{array}$} & \multirow{2}{*}{$\begin{array}{c}\text { Current } \\
\text { week }\end{array}$} & \multicolumn{2}{|c|}{$\begin{array}{l}\text { Previous } \\
52 \text { weeks } \\
\end{array}$} & \multirow{2}{*}{$\begin{array}{l}\text { Cum } \\
2006 \\
\end{array}$} & \multirow{2}{*}{$\begin{array}{c}\text { Cum } \\
2005 \\
\end{array}$} & \multirow{2}{*}{$\begin{array}{c}\text { Current } \\
\text { week }\end{array}$} & \multicolumn{2}{|c|}{$\begin{array}{l}\text { Previous } \\
52 \text { weeks } \\
\end{array}$} & \multirow{2}{*}{$\begin{array}{c}\text { Cum } \\
2006 \\
\end{array}$} & \multirow{2}{*}{$\begin{array}{l}\text { Cum } \\
2005 \\
\end{array}$} \\
\hline & & Med & Max & & & & Med & Max & & & & Med & $\operatorname{Max}$ & & \\
\hline United States & 8 & 20 & 85 & 787 & 909 & 5 & 13 & 58 & 518 & 555 & 105 & 273 & 2,877 & 8,784 & 15,304 \\
\hline $\begin{array}{l}\text { New England } \\
\text { Connecticut } \\
\text { Maine }^{\dagger} \\
\text { Massachusetts } \\
\text { New Hampshire } \\
\text { Rhode Island } \\
\text { Vermont }^{\dagger}\end{array}$ & $\begin{array}{l}\frac{1}{-} \\
\frac{1}{-} \\
-\end{array}$ & $\begin{array}{l}1 \\
0 \\
0 \\
0 \\
0 \\
0 \\
0\end{array}$ & $\begin{array}{l}3 \\
2 \\
1 \\
2 \\
2 \\
1 \\
1\end{array}$ & $\begin{array}{r}35 \\
9 \\
4 \\
15 \\
5 \\
2\end{array}$ & $\begin{array}{r}58 \\
12 \\
2 \\
27 \\
10 \\
2 \\
5\end{array}$ & $\begin{array}{l}\frac{1}{-} \\
\frac{1}{-} \\
-\end{array}$ & $\begin{array}{l}0 \\
0 \\
0 \\
0 \\
0 \\
0 \\
0\end{array}$ & $\begin{array}{l}2 \\
2 \\
1 \\
2 \\
2 \\
0 \\
0\end{array}$ & $\begin{array}{r}25 \\
2 \\
3 \\
15 \\
5 \\
- \\
-\end{array}$ & $\begin{array}{r}20 \\
1 \\
2 \\
5 \\
10 \\
- \\
2\end{array}$ & $\begin{array}{l}\frac{6}{2} \\
2 \\
-1 \\
-1\end{array}$ & $\begin{array}{r}28 \\
1 \\
1 \\
22 \\
2 \\
0 \\
1\end{array}$ & $\begin{array}{r}83 \\
5 \\
7 \\
43 \\
36 \\
17 \\
14\end{array}$ & $\begin{array}{r}876 \\
32 \\
41 \\
594 \\
122 \\
87\end{array}$ & $\begin{array}{r}919 \\
49 \\
31 \\
702 \\
45 \\
21 \\
71\end{array}$ \\
\hline $\begin{array}{l}\text { Mid. Atlantic } \\
\text { New Jersey } \\
\text { New York (Upstate) } \\
\text { New York City } \\
\text { Pennsylvania }\end{array}$ & $\begin{array}{l}- \\
- \\
-\end{array}$ & $\begin{array}{l}3 \\
0 \\
1 \\
0 \\
1\end{array}$ & $\begin{array}{r}14 \\
2 \\
7 \\
6 \\
5\end{array}$ & $\begin{array}{r}118 \\
11 \\
31 \\
39 \\
37\end{array}$ & $\begin{array}{r}111 \\
26 \\
31 \\
17 \\
37\end{array}$ & $\begin{array}{l}- \\
- \\
-\end{array}$ & $\begin{array}{l}2 \\
0 \\
0 \\
0 \\
1\end{array}$ & $\begin{array}{r}11 \\
2 \\
5 \\
6 \\
5\end{array}$ & $\begin{array}{r}89 \\
11 \\
6 \\
39 \\
33\end{array}$ & $\begin{array}{l}85 \\
26 \\
11 \\
17 \\
31\end{array}$ & $\frac{37}{\frac{26}{11}}$ & $\begin{array}{r}32 \\
4 \\
13 \\
1 \\
11\end{array}$ & $\begin{array}{r}137 \\
13 \\
123 \\
8 \\
26\end{array}$ & $\begin{array}{r}1,207 \\
142 \\
532 \\
52 \\
481\end{array}$ & $\begin{array}{r}934 \\
131 \\
350 \\
75 \\
378\end{array}$ \\
\hline $\begin{array}{l}\text { E.N. Central } \\
\text { Illinois } \\
\text { Indiana } \\
\text { Michigan } \\
\text { Ohio } \\
\text { Wisconsin }\end{array}$ & $\begin{array}{l}\frac{3}{2} \\
\frac{1}{-} \\
-\end{array}$ & $\begin{array}{l}2 \\
0 \\
0 \\
0 \\
1 \\
0\end{array}$ & $\begin{array}{r}11 \\
4 \\
5 \\
3 \\
5 \\
2\end{array}$ & $\begin{array}{r}91 \\
18 \\
20 \\
17 \\
33 \\
3\end{array}$ & $\begin{array}{r}115 \\
26 \\
16 \\
23 \\
31 \\
19\end{array}$ & $\begin{array}{l}\frac{3}{2} \\
\frac{1}{1} \\
-\end{array}$ & $\begin{array}{l}1 \\
0 \\
0 \\
0 \\
1 \\
0\end{array}$ & $\begin{array}{l}6 \\
4 \\
2 \\
3 \\
4 \\
2\end{array}$ & $\begin{array}{r}65 \\
18 \\
9 \\
8 \\
27 \\
3\end{array}$ & $\begin{array}{r}95 \\
26 \\
7 \\
14 \\
29 \\
19 \\
19\end{array}$ & $\begin{array}{l}\frac{11}{4} \\
\frac{7}{-}\end{array}$ & $\begin{array}{r}42 \\
9 \\
4 \\
7 \\
14 \\
6\end{array}$ & $\begin{array}{r}133 \\
35 \\
75 \\
23 \\
30 \\
41\end{array}$ & $\begin{array}{r}1,250 \\
227 \\
157 \\
324 \\
410 \\
132\end{array}$ & $\begin{array}{r}2,591 \\
609 \\
209 \\
190 \\
810 \\
773\end{array}$ \\
\hline $\begin{array}{l}\text { W.N. Central } \\
\text { lowa } \\
\text { Kansas } \\
\text { Minnesota } \\
\text { Missouri } \\
\text { Nebraska } \\
\text { North Dakota } \\
\text { South Dakota }\end{array}$ & $\begin{array}{l}- \\
- \\
- \\
- \\
-\end{array}$ & $\begin{array}{l}1 \\
0 \\
0 \\
0 \\
0 \\
0 \\
0 \\
0\end{array}$ & $\begin{array}{l}4 \\
2 \\
1 \\
2 \\
2 \\
2 \\
1 \\
1\end{array}$ & $\begin{array}{r}43 \\
12 \\
1 \\
10 \\
13 \\
5 \\
1 \\
1\end{array}$ & $\begin{array}{r}62 \\
15 \\
9 \\
11 \\
20 \\
4 \\
\frac{1}{3}\end{array}$ & $\begin{array}{l}- \\
- \\
- \\
- \\
-\end{array}$ & $\begin{array}{l}0 \\
0 \\
0 \\
0 \\
0 \\
0 \\
0 \\
0\end{array}$ & $\begin{array}{l}3 \\
1 \\
1 \\
1 \\
1 \\
1 \\
1 \\
0\end{array}$ & $\begin{array}{r}14 \\
4 \\
1 \\
3 \\
2 \\
3 \\
1 \\
-\end{array}$ & $\begin{array}{r}27 \\
1 \\
9 \\
4 \\
10 \\
3 \\
-\end{array}$ & $\begin{array}{l}\frac{6}{6} \\
- \\
- \\
- \\
-\end{array}$ & $\begin{array}{r}30 \\
6 \\
8 \\
0 \\
7 \\
3 \\
0 \\
1\end{array}$ & $\begin{array}{r}552 \\
63 \\
28 \\
485 \\
42 \\
10 \\
26 \\
7\end{array}$ & $\begin{array}{r}833 \\
192 \\
206 \\
137 \\
184 \\
71 \\
26 \\
17\end{array}$ & $\begin{array}{r}2,430 \\
548 \\
252 \\
868 \\
316 \\
212 \\
80 \\
154\end{array}$ \\
\hline $\begin{array}{l}\text { S. Atlantic } \\
\text { Delaware } \\
\text { District of Columbia } \\
\text { Florida } \\
\text { Georgia } \\
\text { Maryland }^{\dagger} \\
\text { North Carolina } \\
\text { South Carolina }^{\dagger} \\
\text { Virginia }^{\dagger} \\
\text { West Virginia }^{\text {Westia }}\end{array}$ & $\begin{array}{l}3 \\
-\overline{3} \\
- \\
- \\
- \\
-\end{array}$ & $\begin{array}{l}3 \\
0 \\
0 \\
1 \\
0 \\
0 \\
0 \\
0 \\
0 \\
0\end{array}$ & $\begin{array}{r}14 \\
1 \\
1 \\
6 \\
3 \\
2 \\
11 \\
2 \\
4 \\
2\end{array}$ & $\begin{array}{r}136 \\
4 \\
1 \\
54 \\
10 \\
9 \\
23 \\
15 \\
15 \\
5\end{array}$ & $\begin{array}{r}167 \\
4 \\
5 \\
61 \\
14 \\
16 \\
27 \\
13 \\
21 \\
6\end{array}$ & $\begin{array}{l}- \\
- \\
- \\
- \\
- \\
-\end{array}$ & $\begin{array}{l}2 \\
0 \\
0 \\
0 \\
0 \\
0 \\
0 \\
0 \\
0 \\
0\end{array}$ & $\begin{array}{l}7 \\
1 \\
1 \\
5 \\
3 \\
1 \\
3 \\
1 \\
3 \\
0\end{array}$ & $\begin{array}{r}54 \\
4 \\
1 \\
19 \\
10 \\
2 \\
7 \\
5 \\
6 \\
-\end{array}$ & $\begin{array}{r}67 \\
4 \\
4 \\
20 \\
14 \\
2 \\
5 \\
8 \\
8 \\
2\end{array}$ & $\begin{array}{l}10 \\
-7 \\
- \\
- \\
- \\
- \\
-\end{array}$ & $\begin{array}{r}22 \\
0 \\
0 \\
4 \\
0 \\
3 \\
0 \\
4 \\
2 \\
0\end{array}$ & $\begin{array}{r}46 \\
1 \\
3 \\
14 \\
3 \\
9 \\
22 \\
22 \\
27 \\
9\end{array}$ & $\begin{array}{r}678 \\
3 \\
3 \\
150 \\
12 \\
88 \\
141 \\
106 \\
149 \\
26\end{array}$ & $\begin{array}{r}1,008 \\
14 \\
7 \\
142 \\
39 \\
149 \\
64 \\
292 \\
264 \\
37\end{array}$ \\
\hline $\begin{array}{l}\text { E.S. Central } \\
\text { Alabama }^{\dagger} \\
\text { Kentucky } \\
\text { Mississippi } \\
\text { Tennessee }^{\dagger}\end{array}$ & $\begin{array}{l}- \\
- \\
-\end{array}$ & $\begin{array}{l}1 \\
0 \\
0 \\
0 \\
0\end{array}$ & $\begin{array}{l}4 \\
1 \\
2 \\
1 \\
2\end{array}$ & $\begin{array}{r}29 \\
5 \\
7 \\
2 \\
15\end{array}$ & $\begin{array}{r}45 \\
5 \\
15 \\
5 \\
20\end{array}$ & $\begin{array}{l}- \\
- \\
-\end{array}$ & $\begin{array}{l}0 \\
0 \\
0 \\
0 \\
0\end{array}$ & $\begin{array}{l}4 \\
1 \\
2 \\
1 \\
2\end{array}$ & $\begin{array}{r}23 \\
4 \\
7 \\
2 \\
10\end{array}$ & $\begin{array}{r}34 \\
3 \\
15 \\
5 \\
11\end{array}$ & $\frac{5}{\frac{5}{2}}$ & $\begin{array}{l}7 \\
1 \\
2 \\
0 \\
2\end{array}$ & $\begin{array}{r}15 \\
7 \\
5 \\
4 \\
10\end{array}$ & $\begin{array}{r}235 \\
51 \\
52 \\
23 \\
109\end{array}$ & $\begin{array}{r}401 \\
63 \\
117 \\
45 \\
176\end{array}$ \\
\hline $\begin{array}{l}\text { W.S. Central } \\
\text { Arkansas } \\
\text { Louisiana } \\
\text { Oklahoma } \\
\text { Texas }^{\dagger}\end{array}$ & $\begin{array}{l}- \\
- \\
-\end{array}$ & $\begin{array}{l}1 \\
0 \\
0 \\
0 \\
1\end{array}$ & $\begin{array}{r}23 \\
3 \\
1 \\
4 \\
16\end{array}$ & $\begin{array}{r}48 \\
9 \\
3 \\
8 \\
28\end{array}$ & $\begin{array}{l}89 \\
11 \\
28 \\
13 \\
37\end{array}$ & $\begin{array}{l}- \\
- \\
-\end{array}$ & $\begin{array}{l}0 \\
0 \\
0 \\
0 \\
0\end{array}$ & $\begin{array}{l}6 \\
2 \\
1 \\
0 \\
4\end{array}$ & $\begin{array}{r}20 \\
6 \\
1 \\
13\end{array}$ & $\begin{array}{r}23 \\
3 \\
5 \\
2 \\
13\end{array}$ & $\begin{array}{l}- \\
- \\
-\end{array}$ & $\begin{array}{r}19 \\
2 \\
0 \\
0 \\
18\end{array}$ & $\begin{array}{r}360 \\
21 \\
3 \\
124 \\
215\end{array}$ & $\begin{array}{r}446 \\
41 \\
5 \\
18 \\
382\end{array}$ & $\begin{array}{r}1,640 \\
231 \\
43 \\
1 \\
1,365\end{array}$ \\
\hline $\begin{array}{l}\text { Mountain } \\
\text { Arizona } \\
\text { Colorado } \\
\text { Idaho }^{\dagger} \\
\text { Montana } \\
\text { Nevada }^{\dagger} \\
\text { New Mexico }^{\dagger} \\
\text { Utah } \\
\text { Wyoming }\end{array}$ & $\begin{array}{l}- \\
- \\
- \\
- \\
-\end{array}$ & $\begin{array}{l}1 \\
0 \\
0 \\
0 \\
0 \\
0 \\
0 \\
0 \\
0\end{array}$ & $\begin{array}{l}5 \\
3 \\
2 \\
2 \\
1 \\
2 \\
1 \\
1 \\
2\end{array}$ & $\begin{array}{r}49 \\
15 \\
15 \\
3 \\
3 \\
2 \\
2 \\
5 \\
4\end{array}$ & $\begin{array}{r}73 \\
30 \\
15 \\
4 \\
-9 \\
5 \\
10 \\
-\end{array}$ & $\begin{array}{l}- \\
- \\
- \\
- \\
- \\
-\end{array}$ & $\begin{array}{l}0 \\
0 \\
0 \\
0 \\
0 \\
0 \\
0 \\
0 \\
0\end{array}$ & $\begin{array}{l}4 \\
3 \\
1 \\
2 \\
1 \\
0 \\
1 \\
0 \\
2\end{array}$ & $\begin{array}{r}25 \\
15 \\
3 \\
2 \\
1 \\
- \\
- \\
4\end{array}$ & $\begin{array}{l}21 \\
10 \\
3 \\
- \\
2 \\
4 \\
2 \\
-\end{array}$ & $\begin{array}{r}30 \\
2 \\
7 \\
1 \\
3 \\
- \\
16 \\
1\end{array}$ & $\begin{array}{r}63 \\
11 \\
21 \\
2 \\
2 \\
0 \\
2 \\
15 \\
1\end{array}$ & $\begin{array}{r}230 \\
177 \\
40 \\
11 \\
11 \\
9 \\
6 \\
39 \\
8\end{array}$ & $\begin{array}{r}1,945 \\
388 \\
580 \\
60 \\
90 \\
39 \\
55 \\
673 \\
60\end{array}$ & $\begin{array}{r}2,933 \\
740 \\
931 \\
156 \\
527 \\
41 \\
143 \\
360 \\
35\end{array}$ \\
\hline $\begin{array}{l}\text { Pacific } \\
\text { Alaska } \\
\text { California } \\
\text { Hawaii } \\
\text { Oregon }^{\dagger} \\
\text { Washington }^{-}\end{array}$ & $\begin{array}{l}\frac{1}{1} \\
- \\
-\end{array}$ & $\begin{array}{l}5 \\
0 \\
3 \\
0 \\
1 \\
0\end{array}$ & $\begin{array}{r}29 \\
1 \\
14 \\
1 \\
7 \\
25\end{array}$ & $\begin{array}{r}238 \\
2 \\
146 \\
6 \\
57 \\
27\end{array}$ & $\begin{array}{r}189 \\
1 \\
124 \\
10 \\
35 \\
19\end{array}$ & $\begin{array}{l}\frac{1}{1} \\
- \\
-\end{array}$ & $\begin{array}{l}5 \\
0 \\
3 \\
0 \\
1 \\
0\end{array}$ & $\begin{array}{r}25 \\
1 \\
14 \\
1 \\
4 \\
4 \\
11\end{array}$ & $\begin{array}{r}203 \\
2 \\
146 \\
6 \\
38 \\
11\end{array}$ & $\begin{array}{r}183 \\
1 \\
124 \\
5 \\
35 \\
18\end{array}$ & $\begin{array}{l}- \\
- \\
- \\
-\end{array}$ & $\begin{array}{r}45 \\
2 \\
28 \\
1 \\
2 \\
7\end{array}$ & $\begin{array}{r}1,334 \\
15 \\
1,136 \\
6 \\
9 \\
195\end{array}$ & $\begin{array}{r}1,314 \\
51 \\
889 \\
52 \\
88 \\
234\end{array}$ & $\begin{array}{r}2,448 \\
79 \\
1,051 \\
130 \\
583 \\
605\end{array}$ \\
\hline $\begin{array}{l}\text { American Samoa } \\
\text { C.N.M.I. } \\
\text { Guam } \\
\text { Puerto Rico } \\
\text { U.S. Virgin Islands }\end{array}$ & $\begin{array}{l}U \\
- \\
-\end{array}$ & $\begin{array}{l}0 \\
0 \\
0 \\
0 \\
0\end{array}$ & $\begin{array}{l}0 \\
0 \\
0 \\
1 \\
0\end{array}$ & $\begin{array}{l}- \\
\frac{4}{4}\end{array}$ & $\begin{array}{l}- \\
1 \\
6 \\
-\end{array}$ & $\begin{array}{l}U \\
U \\
- \\
-\end{array}$ & $\begin{array}{l}0 \\
0 \\
0 \\
0 \\
0\end{array}$ & $\begin{array}{l}0 \\
0 \\
0 \\
1 \\
0\end{array}$ & $\frac{U}{U}$ & $\begin{array}{r}U \\
U \\
1 \\
6 \\
-\end{array}$ & $\begin{array}{l}U \\
U \\
- \\
-\end{array}$ & $\begin{array}{l}0 \\
0 \\
0 \\
0 \\
0\end{array}$ & $\begin{array}{l}0 \\
0 \\
0 \\
1 \\
0\end{array}$ & $\begin{array}{l}U \\
\frac{U}{1} \\
-\end{array}$ & $\begin{array}{l}U \\
U \\
2 \\
5 \\
\end{array}$ \\
\hline
\end{tabular}

C.N.M.I.: Commonwealth of Northern Mariana Islands.

U: Unavailable. - No reported cases. N: Not notifiable.

Cum: Cumulative year-to-date counts.

Med: Median

Max: Maximum

* Incidence data for reporting years 2005 and 2006 are provisional.

Contains data reported through the National Electronic Disease Surveillance System (NEDSS). 
TABLE II. (Continued) Provisional cases of selected notifiable diseases, United States, weeks ending September 9, 2006, and September 10, 2005 (36th Week)*

\begin{tabular}{|c|c|c|c|c|c|c|c|c|c|c|c|c|c|c|c|}
\hline \multirow[b]{3}{*}{ Reporting area } & \multicolumn{5}{|c|}{ Rabies, animal } & \multicolumn{5}{|c|}{ Rocky Mountain spotted fever } & \multicolumn{5}{|c|}{ Salmonellosis } \\
\hline & \multirow{2}{*}{$\begin{array}{c}\text { Current } \\
\text { week }\end{array}$} & \multicolumn{2}{|c|}{$\begin{array}{l}\text { Previous } \\
52 \text { weeks }\end{array}$} & \multirow{2}{*}{$\begin{array}{l}\text { Cum } \\
2006\end{array}$} & \multirow{2}{*}{$\begin{array}{l}\text { Cum } \\
2005\end{array}$} & \multirow{2}{*}{$\begin{array}{c}\text { Current } \\
\text { week }\end{array}$} & \multicolumn{2}{|c|}{$\begin{array}{l}\text { Previous } \\
52 \text { weeks }\end{array}$} & \multirow{2}{*}{$\begin{array}{l}\text { Cum } \\
2006\end{array}$} & \multirow{2}{*}{$\begin{array}{l}\text { Cum } \\
2005\end{array}$} & \multirow{2}{*}{$\begin{array}{c}\text { Current } \\
\text { week }\end{array}$} & \multicolumn{2}{|c|}{$\begin{array}{l}\text { Previous } \\
52 \text { weeks }\end{array}$} & \multirow{2}{*}{$\begin{array}{l}\text { Cum } \\
2006\end{array}$} & \multirow{2}{*}{$\begin{array}{l}\text { Cum } \\
2005\end{array}$} \\
\hline & & Med & $\operatorname{Max}$ & & & & Med & $\operatorname{Max}$ & & & & Med & $\operatorname{Max}$ & & \\
\hline United States & 79 & 111 & 166 & 4,021 & 4,304 & 22 & 36 & 246 & 1,268 & 1,149 & 688 & 809 & 2,291 & 25,422 & 28,397 \\
\hline $\begin{array}{l}\text { New England } \\
\text { Connecticut } \\
\text { Maine }^{\dagger} \\
\text { Massachusetts } \\
\text { New Hampshire } \\
\text { Rhode Island } \\
\text { Vermont }^{\dagger}\end{array}$ & $\begin{array}{r}24 \\
11 \\
2 \\
4 \\
3 \\
-4\end{array}$ & $\begin{array}{r}12 \\
3 \\
1 \\
4 \\
0 \\
0 \\
1\end{array}$ & $\begin{array}{r}25 \\
14 \\
5 \\
17 \\
5 \\
4 \\
4\end{array}$ & $\begin{array}{r}465 \\
135 \\
69 \\
178 \\
36 \\
1 \\
46\end{array}$ & $\begin{array}{r}528 \\
138 \\
47 \\
272 \\
11 \\
16 \\
44\end{array}$ & $\begin{array}{l}- \\
\bar{N} \\
- \\
-\end{array}$ & $\begin{array}{l}0 \\
0 \\
0 \\
0 \\
0 \\
0 \\
0\end{array}$ & $\begin{array}{l}2 \\
0 \\
0 \\
2 \\
1 \\
2 \\
0\end{array}$ & $\begin{array}{r}2 \\
\mathrm{~N} \\
1 \\
1 \\
-\end{array}$ & $\begin{array}{l}5 \\
N \\
3 \\
1 \\
1 \\
-\end{array}$ & $\begin{array}{l}\frac{15}{-} \\
\frac{8}{2} \\
\frac{5}{5}\end{array}$ & $\begin{array}{r}34 \\
0 \\
2 \\
19 \\
2 \\
0 \\
1\end{array}$ & $\begin{array}{r}324 \\
316 \\
10 \\
53 \\
24 \\
17 \\
4\end{array}$ & $\begin{array}{r}1,409 \\
316 \\
80 \\
782 \\
133 \\
57 \\
41\end{array}$ & $\begin{array}{r}1,576 \\
328 \\
126 \\
838 \\
136 \\
73 \\
75\end{array}$ \\
\hline $\begin{array}{l}\text { Mid. Atlantic } \\
\text { New Jersey } \\
\text { New York (Upstate) } \\
\text { New York City } \\
\text { Pennsylvania }\end{array}$ & $\begin{array}{r}11 \\
N \\
11 \\
- \\
-\end{array}$ & $\begin{array}{r}20 \\
0 \\
11 \\
0 \\
9\end{array}$ & $\begin{array}{r}50 \\
0 \\
20 \\
3 \\
35\end{array}$ & $\begin{array}{r}795 \\
N \\
380 \\
\\
415\end{array}$ & $\begin{array}{r}678 \\
\mathrm{~N} \\
375 \\
20 \\
283\end{array}$ & $\begin{array}{l}- \\
- \\
-\end{array}$ & $\begin{array}{l}1 \\
0 \\
0 \\
0 \\
1\end{array}$ & $\begin{array}{l}6 \\
2 \\
1 \\
1 \\
3\end{array}$ & $\begin{array}{r}34 \\
7 \\
2 \\
3 \\
22\end{array}$ & $\begin{array}{r}69 \\
21 \\
1 \\
6 \\
41\end{array}$ & $\frac{52}{\frac{33}{19}}$ & $\begin{array}{l}82 \\
14 \\
22 \\
16 \\
28\end{array}$ & $\begin{array}{r}272 \\
39 \\
233 \\
44 \\
65\end{array}$ & $\begin{array}{r}2,914 \\
576 \\
784 \\
492 \\
1,062\end{array}$ & $\begin{array}{r}3,550 \\
712 \\
821 \\
822 \\
1,195\end{array}$ \\
\hline $\begin{array}{l}\text { E.N. Central } \\
\text { Illinois } \\
\text { Indiana } \\
\text { Michigan } \\
\text { Ohio } \\
\text { Wisconsin }\end{array}$ & $\begin{array}{l}\frac{1}{1} \\
\frac{1}{N}\end{array}$ & $\begin{array}{l}2 \\
0 \\
0 \\
1 \\
0 \\
0\end{array}$ & $\begin{array}{r}17 \\
7 \\
2 \\
5 \\
9 \\
0\end{array}$ & $\begin{array}{r}126 \\
37 \\
10 \\
39 \\
40 \\
\mathrm{~N}\end{array}$ & $\begin{array}{r}149 \\
38 \\
10 \\
31 \\
70 \\
\mathrm{~N}\end{array}$ & $\begin{array}{l}- \\
- \\
- \\
-\end{array}$ & $\begin{array}{l}0 \\
0 \\
0 \\
0 \\
0 \\
0\end{array}$ & $\begin{array}{l}4 \\
1 \\
1 \\
1 \\
4 \\
1\end{array}$ & $\begin{array}{r}24 \\
1 \\
5 \\
2 \\
15 \\
1\end{array}$ & $\begin{array}{r}36 \\
11 \\
5 \\
18 \\
2\end{array}$ & $\begin{array}{r}43 \\
10 \\
5 \\
28 \\
-\end{array}$ & $\begin{array}{r}101 \\
26 \\
14 \\
17 \\
23 \\
15\end{array}$ & $\begin{array}{r}189 \\
46 \\
67 \\
32 \\
56 \\
28\end{array}$ & $\begin{array}{r}3,419 \\
833 \\
568 \\
628 \\
852 \\
538\end{array}$ & $\begin{array}{r}4,075 \\
1,390 \\
393 \\
668 \\
924 \\
700\end{array}$ \\
\hline $\begin{array}{l}\text { W.N. Central } \\
\text { lowa } \\
\text { Kansas } \\
\text { Minnesota } \\
\text { Missouri } \\
\text { Nebraska }^{\dagger} \\
\text { North Dakota } \\
\text { South Dakota }\end{array}$ & $\begin{array}{l}\frac{2}{-} \\
\frac{1}{-} \\
-1 \\
-\end{array}$ & $\begin{array}{l}5 \\
0 \\
1 \\
1 \\
1 \\
0 \\
0 \\
0\end{array}$ & $\begin{array}{r}20 \\
7 \\
5 \\
6 \\
4 \\
0 \\
7 \\
4\end{array}$ & $\begin{array}{r}215 \\
47 \\
58 \\
35 \\
38 \\
16 \\
21\end{array}$ & $\begin{array}{r}257 \\
64 \\
55 \\
58 \\
25 \\
55\end{array}$ & $\begin{array}{l}1 \\
- \\
- \\
-1 \\
-\end{array}$ & $\begin{array}{l}2 \\
0 \\
0 \\
0 \\
1 \\
0 \\
0 \\
0\end{array}$ & $\begin{array}{r}13 \\
2 \\
1 \\
1 \\
10 \\
5 \\
1 \\
0\end{array}$ & $\begin{array}{r}125 \\
4 \\
1 \\
2 \\
99 \\
19 \\
-\end{array}$ & $\begin{array}{r}125 \\
5 \\
5 \\
2 \\
103 \\
5 \\
-5\end{array}$ & $\begin{array}{r}37 \\
6 \\
24 \\
- \\
5 \\
2 \\
-\end{array}$ & $\begin{array}{r}43 \\
7 \\
7 \\
10 \\
13 \\
3 \\
0 \\
2\end{array}$ & $\begin{array}{r}107 \\
19 \\
15 \\
60 \\
35 \\
12 \\
46 \\
6\end{array}$ & $\begin{array}{r}1,670 \\
290 \\
246 \\
467 \\
441 \\
127 \\
19 \\
80\end{array}$ & $\begin{array}{r}1,761 \\
287 \\
259 \\
392 \\
538 \\
140 \\
22 \\
123\end{array}$ \\
\hline $\begin{array}{l}\text { S. Atlantic } \\
\text { Delaware } \\
\text { District of Columbia } \\
\text { Florida } \\
\text { Georgia } \\
\text { Maryland }^{\dagger} \\
\text { North Carolina } \\
\text { South Carolina }^{\dagger} \\
\text { Virginia }^{\dagger} \\
\text { West Virginia }^{\text {West }}\end{array}$ & $\begin{array}{r}28 \\
- \\
- \\
- \\
\overline{13} \\
4 \\
8 \\
3\end{array}$ & $\begin{array}{r}36 \\
0 \\
0 \\
0 \\
3 \\
8 \\
8 \\
3 \\
10 \\
1\end{array}$ & $\begin{array}{r}118 \\
0 \\
0 \\
99 \\
9 \\
14 \\
22 \\
10 \\
27 \\
13\end{array}$ & $\begin{array}{r}1,433 \\
- \\
121 \\
99 \\
254 \\
353 \\
112 \\
420 \\
74\end{array}$ & $\begin{array}{r}1,569 \\
- \\
201 \\
199 \\
268 \\
357 \\
162 \\
342 \\
40\end{array}$ & $\begin{array}{l}11 \\
- \\
- \\
- \\
2 \\
8 \\
- \\
-\end{array}$ & $\begin{array}{r}18 \\
0 \\
0 \\
0 \\
0 \\
1 \\
15 \\
1 \\
2 \\
0\end{array}$ & $\begin{array}{r}94 \\
3 \\
1 \\
3 \\
3 \\
4 \\
87 \\
6 \\
13 \\
2\end{array}$ & $\begin{array}{r}763 \\
17 \\
1 \\
14 \\
17 \\
40 \\
578 \\
22 \\
71 \\
3\end{array}$ & $\begin{array}{r}596 \\
5 \\
2 \\
12 \\
79 \\
55 \\
329 \\
47 \\
62 \\
5\end{array}$ & $\begin{array}{r}301 \\
1 \\
-117 \\
27 \\
15 \\
130 \\
10 \\
1 \\
-\end{array}$ & $\begin{array}{r}205 \\
2 \\
1 \\
95 \\
27 \\
12 \\
32 \\
18 \\
20 \\
3\end{array}$ & $\begin{array}{r}514 \\
9 \\
7 \\
230 \\
87 \\
30 \\
114 \\
73 \\
62 \\
19\end{array}$ & $\begin{array}{r}6,676 \\
91 \\
39 \\
2,909 \\
946 \\
458 \\
981 \\
535 \\
639 \\
78\end{array}$ & $\begin{array}{r}7,544 \\
82 \\
39 \\
2,792 \\
1,218 \\
560 \\
1,005 \\
979 \\
762 \\
107\end{array}$ \\
\hline $\begin{array}{l}\text { E.S. Central } \\
\text { Alabama }^{\dagger} \\
\text { Kentucky } \\
\text { Mississippi } \\
\text { Tennessee }^{\dagger}\end{array}$ & $\begin{array}{r}3 \\
2 \\
1 \\
- \\
-\end{array}$ & $\begin{array}{l}4 \\
1 \\
0 \\
0 \\
2\end{array}$ & $\begin{array}{r}16 \\
7 \\
5 \\
2 \\
9\end{array}$ & $\begin{array}{r}175 \\
57 \\
18 \\
4 \\
96\end{array}$ & $\begin{array}{r}107 \\
58 \\
8 \\
4 \\
37\end{array}$ & $\begin{array}{r}1 \\
1 \\
- \\
-\end{array}$ & $\begin{array}{l}5 \\
1 \\
0 \\
0 \\
3\end{array}$ & $\begin{array}{r}21 \\
6 \\
1 \\
2 \\
17\end{array}$ & $\begin{array}{r}192 \\
47 \\
1 \\
2 \\
142\end{array}$ & $\begin{array}{r}216 \\
59 \\
2 \\
11 \\
144\end{array}$ & $\begin{array}{r}55 \\
34 \\
7 \\
14\end{array}$ & $\begin{array}{r}49 \\
13 \\
8 \\
12 \\
14\end{array}$ & $\begin{array}{r}137 \\
65 \\
21 \\
62 \\
31\end{array}$ & $\begin{array}{r}1,685 \\
552 \\
286 \\
363 \\
484\end{array}$ & $\begin{array}{r}1,951 \\
462 \\
329 \\
586 \\
574\end{array}$ \\
\hline $\begin{array}{l}\text { W.S. Central } \\
\text { Arkansas } \\
\text { Louisiana } \\
\text { Oklahoma } \\
\text { Texas }^{\dagger}\end{array}$ & $\begin{array}{l}- \\
- \\
-\end{array}$ & $\begin{array}{r}14 \\
0 \\
0 \\
1 \\
13\end{array}$ & $\begin{array}{r}34 \\
4 \\
0 \\
9 \\
29\end{array}$ & $\begin{array}{r}546 \\
24 \\
51 \\
471\end{array}$ & $\begin{array}{r}662 \\
26 \\
61 \\
575\end{array}$ & $\begin{array}{l}8 \\
8 \\
- \\
-\end{array}$ & $\begin{array}{l}1 \\
0 \\
0 \\
0 \\
0\end{array}$ & $\begin{array}{r}161 \\
32 \\
0 \\
154 \\
3\end{array}$ & $\begin{array}{l}88 \\
42 \\
35 \\
11\end{array}$ & $\begin{array}{r}75 \\
44 \\
6 \\
7 \\
18\end{array}$ & $\begin{array}{r}39 \\
18 \\
17 \\
4\end{array}$ & $\begin{array}{r}80 \\
14 \\
6 \\
7 \\
46\end{array}$ & $\begin{array}{r}922 \\
43 \\
38 \\
48 \\
839\end{array}$ & $\begin{array}{r}2,270 \\
544 \\
180 \\
304 \\
1,242\end{array}$ & $\begin{array}{r}2,681 \\
489 \\
616 \\
275 \\
1,301\end{array}$ \\
\hline $\begin{array}{l}\text { Mountain } \\
\text { Arizona } \\
\text { Colorado } \\
\text { Idaho }^{\dagger} \\
\text { Montana } \\
\text { Nevada }^{\dagger} \\
\text { New Mexico }^{\dagger} \\
\text { Utah } \\
\text { Wyoming }\end{array}$ & $\begin{array}{l}3 \\
3 \\
- \\
- \\
- \\
- \\
-\end{array}$ & $\begin{array}{l}3 \\
2 \\
0 \\
0 \\
0 \\
0 \\
0 \\
0 \\
0\end{array}$ & $\begin{array}{r}16 \\
11 \\
1 \\
12 \\
2 \\
1 \\
2 \\
1 \\
2\end{array}$ & $\begin{array}{r}123 \\
95 \\
- \\
11 \\
7 \\
6 \\
4\end{array}$ & $\begin{array}{r}200 \\
126 \\
16 \\
12 \\
12 \\
8 \\
12 \\
14\end{array}$ & $\begin{array}{l}1 \\
- \\
- \\
- \\
- \\
-\end{array}$ & $\begin{array}{l}0 \\
0 \\
0 \\
0 \\
0 \\
0 \\
0 \\
0 \\
0\end{array}$ & $\begin{array}{l}6 \\
6 \\
1 \\
3 \\
2 \\
0 \\
2 \\
2 \\
1\end{array}$ & $\begin{array}{r}33 \\
6 \\
2 \\
8 \\
2 \\
5 \\
6 \\
4\end{array}$ & $\begin{array}{r}25 \\
12 \\
4 \\
3 \\
1 \\
- \\
3 \\
2\end{array}$ & $\begin{array}{r}36 \\
15 \\
10 \\
5 \\
3 \\
- \\
3 \\
-\end{array}$ & $\begin{array}{r}50 \\
15 \\
12 \\
3 \\
3 \\
2 \\
4 \\
5 \\
1\end{array}$ & $\begin{array}{r}84 \\
67 \\
30 \\
9 \\
16 \\
17 \\
12 \\
15 \\
5\end{array}$ & $\begin{array}{r}1,634 \\
531 \\
414 \\
124 \\
97 \\
71 \\
155 \\
207 \\
35\end{array}$ & $\begin{array}{r}1,639 \\
440 \\
421 \\
110 \\
64 \\
126 \\
188 \\
227 \\
63\end{array}$ \\
\hline $\begin{array}{l}\text { Pacific } \\
\text { Alaska } \\
\text { California } \\
\text { Hawaii } \\
\text { Oregon }^{\dagger} \\
\text { Washington }^{-}\end{array}$ & $\begin{array}{c}\frac{7}{4} \\
\frac{4}{3} \\
\cup\end{array}$ & $\begin{array}{l}4 \\
0 \\
3 \\
0 \\
0 \\
0\end{array}$ & $\begin{array}{r}10 \\
4 \\
10 \\
0 \\
4 \\
0\end{array}$ & $\begin{array}{r}143 \\
14 \\
115 \\
14 \\
\text { U }\end{array}$ & $\begin{array}{r}154 \\
1 \\
149 \\
4 \\
U\end{array}$ & $\begin{array}{l}- \\
- \\
\frac{-}{N}\end{array}$ & $\begin{array}{l}0 \\
0 \\
0 \\
0 \\
0 \\
0\end{array}$ & $\begin{array}{l}1 \\
0 \\
1 \\
0 \\
1 \\
0\end{array}$ & $\begin{array}{l}\frac{7}{5} \\
\frac{2}{2} \\
\mathrm{~N}\end{array}$ & $\begin{array}{l}\frac{2}{-} \\
- \\
2 \\
N\end{array}$ & $\begin{array}{r}110 \\
2 \\
106 \\
-2 \\
-\end{array}$ & $\begin{array}{r}109 \\
1 \\
86 \\
4 \\
7 \\
8\end{array}$ & $\begin{array}{r}426 \\
7 \\
292 \\
15 \\
16 \\
124\end{array}$ & $\begin{array}{r}3,745 \\
54 \\
2,963 \\
145 \\
280 \\
303\end{array}$ & $\begin{array}{r}3,620 \\
39 \\
2,715 \\
211 \\
298 \\
357\end{array}$ \\
\hline $\begin{array}{l}\text { American Samoa } \\
\text { C.N.M.I. } \\
\text { Guam } \\
\text { Puerto Rico } \\
\text { U.S. Virgin Islands }\end{array}$ & $\frac{U}{U} \frac{U}{-}$ & $\begin{array}{l}0 \\
0 \\
0 \\
1 \\
0\end{array}$ & $\begin{array}{l}0 \\
0 \\
0 \\
6 \\
0\end{array}$ & $\frac{U}{U}$ & $\frac{U}{U}$ & $\frac{U}{U}$ & $\begin{array}{l}0 \\
0 \\
0 \\
0 \\
0\end{array}$ & $\begin{array}{l}0 \\
0 \\
0 \\
0 \\
0\end{array}$ & $\begin{array}{l}U \\
\frac{U}{N} \\
-\end{array}$ & $\frac{U}{U} \frac{U}{-}$ & $\frac{U}{U} \frac{U}{-}$ & $\begin{array}{l}0 \\
0 \\
1 \\
5 \\
0\end{array}$ & $\begin{array}{r}2 \\
0 \\
3 \\
35 \\
0\end{array}$ & $\begin{array}{r}U \\
\frac{U}{134} \\
-\end{array}$ & $\begin{array}{r}4 \\
U \\
30 \\
442 \\
-\end{array}$ \\
\hline
\end{tabular}

C.N.M.I.: Commonwealth of Northern Mariana Islands.

U: Unavailable. ․: No reported cases. N: Not notifiable. Cum: Cumulative year-to-date counts. Med: Median. Max: Maximum.

* Incidence data for reporting years 2005 and 2006 are provisional.

Contains data reported through the National Electronic Disease Surveillance System (NEDSS). 
TABLE II. (Continued) Provisional cases of selected notifiable diseases, United States, weeks ending September 9, 2006, and September 10, 2005 (36th Week)*

\begin{tabular}{|c|c|c|c|c|c|c|c|c|c|c|c|c|c|c|c|}
\hline \multirow[b]{3}{*}{ Reporting area } & \multicolumn{5}{|c|}{ Shiga toxin-producing E. coli (STEC) ${ }^{\dagger}$} & \multicolumn{5}{|c|}{ Shigellosis } & \multicolumn{5}{|c|}{ Streptococcal disease, invasive, group A } \\
\hline & \multirow{2}{*}{$\begin{array}{c}\text { Current } \\
\text { week }\end{array}$} & \multicolumn{2}{|c|}{$\begin{array}{l}\text { Previous } \\
52 \text { weeks }\end{array}$} & \multirow{2}{*}{$\begin{array}{l}\text { Cum } \\
2006 \\
\end{array}$} & \multirow{2}{*}{$\begin{array}{l}\text { Cum } \\
2005\end{array}$} & \multirow{2}{*}{$\begin{array}{c}\text { Current } \\
\text { week }\end{array}$} & \multicolumn{2}{|c|}{$\begin{array}{l}\text { Previous } \\
52 \text { weeks }\end{array}$} & \multirow{2}{*}{$\begin{array}{l}\text { Cum } \\
2006\end{array}$} & \multirow{2}{*}{$\begin{array}{l}\text { Cum } \\
2005\end{array}$} & \multirow{2}{*}{$\begin{array}{c}\text { Current } \\
\text { week }\end{array}$} & \multicolumn{2}{|c|}{$\begin{array}{l}\text { Previous } \\
52 \text { weeks } \\
\end{array}$} & \multirow{2}{*}{$\begin{array}{l}\text { Cum } \\
2006\end{array}$} & \multirow{2}{*}{$\begin{array}{l}\text { Cum } \\
2005 \\
\end{array}$} \\
\hline & & Med & Max & & & & Med & Max & & & & Med & $\operatorname{Max}$ & & \\
\hline United States & 81 & 55 & 297 & 1,769 & 1,926 & 163 & 227 & 1,013 & 7,039 & 9,604 & 38 & 87 & 283 & 3,611 & 3,390 \\
\hline $\begin{array}{l}\text { New England } \\
\text { Connecticut } \\
\text { Maine§ } \\
\text { Massachusetts } \\
\text { New Hampshire } \\
\text { Rhode Island } \\
\text { Vermont }{ }^{\S}\end{array}$ & $\begin{array}{l}\frac{2}{-} \\
- \\
1 \\
-\end{array}$ & $\begin{array}{l}3 \\
0 \\
0 \\
2 \\
0 \\
0 \\
0\end{array}$ & $\begin{array}{r}50 \\
49 \\
8 \\
9 \\
3 \\
2 \\
2\end{array}$ & $\begin{array}{r}190 \\
49 \\
23 \\
82 \\
19 \\
5 \\
2\end{array}$ & $\begin{array}{r}149 \\
37 \\
27 \\
56 \\
13 \\
3 \\
13\end{array}$ & $\begin{array}{l}\frac{2}{-} \\
\frac{2}{-} \\
-\end{array}$ & $\begin{array}{l}4 \\
0 \\
0 \\
3 \\
0 \\
0 \\
0\end{array}$ & $\begin{array}{r}51 \\
45 \\
2 \\
11 \\
4 \\
6 \\
1\end{array}$ & $\begin{array}{r}194 \\
45 \\
3 \\
128 \\
7 \\
8 \\
3\end{array}$ & $\begin{array}{r}226 \\
38 \\
12 \\
140 \\
8 \\
12 \\
16\end{array}$ & $\begin{array}{l}\frac{2}{U} \\
\frac{-}{-} \\
\frac{1}{1}\end{array}$ & $\begin{array}{l}5 \\
0 \\
0 \\
3 \\
0 \\
0 \\
0\end{array}$ & $\begin{array}{r}15 \\
3 \\
2 \\
6 \\
9 \\
3 \\
2\end{array}$ & $\begin{array}{r}170 \\
U \\
15 \\
101 \\
39 \\
5 \\
10\end{array}$ & $\begin{array}{r}212 \\
80 \\
12 \\
89 \\
14 \\
8 \\
9\end{array}$ \\
\hline $\begin{array}{l}\text { Mid. Atlantic } \\
\text { New Jersey } \\
\text { New York (Upstate) } \\
\text { New York City } \\
\text { Pennsylvania }\end{array}$ & $\begin{array}{l}\frac{15}{-} \\
-\end{array}$ & $\begin{array}{l}5 \\
0 \\
0 \\
0 \\
0\end{array}$ & $\begin{array}{r}107 \\
7 \\
103 \\
4 \\
5\end{array}$ & $\begin{array}{r}132 \\
3 \\
12 \\
17 \\
5\end{array}$ & $\begin{array}{r}223 \\
47 \\
79 \\
10 \\
87\end{array}$ & $\frac{4}{\frac{2}{2}}$ & $\begin{array}{r}15 \\
4 \\
5 \\
4 \\
2\end{array}$ & $\begin{array}{l}72 \\
24 \\
60 \\
12 \\
48\end{array}$ & $\begin{array}{r}510 \\
189 \\
168 \\
96 \\
57\end{array}$ & $\begin{array}{l}898 \\
241 \\
193 \\
308 \\
156\end{array}$ & $\frac{6}{\frac{1}{5}}$ & $\begin{array}{r}15 \\
3 \\
4 \\
1 \\
6\end{array}$ & $\begin{array}{r}43 \\
8 \\
32 \\
10 \\
13\end{array}$ & $\begin{array}{r}671 \\
122 \\
239 \\
73 \\
237\end{array}$ & $\begin{array}{l}695 \\
146 \\
197 \\
137 \\
215\end{array}$ \\
\hline $\begin{array}{l}\text { E.N. Central } \\
\text { Illinois } \\
\text { Indiana } \\
\text { Michigan } \\
\text { Ohio } \\
\text { Wisconsin }\end{array}$ & $\begin{array}{r}31 \\
- \\
19 \\
8\end{array}$ & $\begin{array}{r}11 \\
1 \\
1 \\
1 \\
3 \\
2\end{array}$ & $\begin{array}{r}38 \\
7 \\
6 \\
6 \\
14 \\
28\end{array}$ & $\begin{array}{r}391 \\
58 \\
48 \\
59 \\
112 \\
114\end{array}$ & $\begin{array}{r}394 \\
108 \\
40 \\
65 \\
87 \\
94\end{array}$ & $\begin{array}{l}\frac{5}{1} \\
\frac{1}{4} \\
-\end{array}$ & $\begin{array}{r}20 \\
7 \\
2 \\
3 \\
3 \\
3\end{array}$ & $\begin{array}{r}41 \\
25 \\
18 \\
10 \\
11 \\
9\end{array}$ & $\begin{array}{r}625 \\
217 \\
88 \\
109 \\
111 \\
100\end{array}$ & $\begin{array}{r}789 \\
256 \\
107 \\
174 \\
76 \\
176\end{array}$ & $\begin{array}{l}\frac{1}{-} \\
\frac{1}{-}\end{array}$ & $\begin{array}{r}14 \\
4 \\
2 \\
3 \\
4 \\
1\end{array}$ & $\begin{array}{r}43 \\
11 \\
11 \\
12 \\
19 \\
4\end{array}$ & $\begin{array}{r}648 \\
144 \\
90 \\
174 \\
198 \\
42\end{array}$ & $\begin{array}{r}720 \\
236 \\
82 \\
171 \\
156 \\
75\end{array}$ \\
\hline $\begin{array}{l}\text { W.N. Central } \\
\text { lowa } \\
\text { Kansas } \\
\text { Minnesota } \\
\text { Missouri } \\
\text { Nebraska } \\
\text { North Dakota } \\
\text { South Dakota }\end{array}$ & $\begin{array}{l}\frac{9}{-} \\
\frac{9}{3} \\
\frac{3}{-}\end{array}$ & $\begin{array}{l}8 \\
2 \\
0 \\
3 \\
2 \\
1 \\
0 \\
0\end{array}$ & $\begin{array}{r}35 \\
8 \\
3 \\
19 \\
13 \\
13 \\
5 \\
15 \\
5\end{array}$ & $\begin{array}{r}255 \\
87 \\
-\overline{144} \\
110 \\
36 \\
\frac{19}{19}\end{array}$ & $\begin{array}{r}305 \\
66 \\
31 \\
76 \\
71 \\
36 \\
3 \\
22\end{array}$ & $\begin{array}{l}\frac{16}{2} \\
2 \\
- \\
2 \\
8 \\
-\end{array}$ & $\begin{array}{r}34 \\
2 \\
4 \\
2 \\
12 \\
12 \\
2 \\
0 \\
4\end{array}$ & $\begin{array}{r}77 \\
10 \\
20 \\
9 \\
69 \\
14 \\
18 \\
17\end{array}$ & $\begin{array}{r}1,014 \\
63 \\
90 \\
86 \\
474 \\
80 \\
61 \\
160\end{array}$ & $\begin{array}{r}1,031 \\
62 \\
138 \\
61 \\
669 \\
69 \\
2 \\
30\end{array}$ & $\begin{array}{l}1 \\
\mathrm{~N} \\
- \\
- \\
- \\
-\end{array}$ & $\begin{array}{l}5 \\
0 \\
1 \\
0 \\
1 \\
0 \\
0 \\
0\end{array}$ & $\begin{array}{r}57 \\
0 \\
5 \\
52 \\
5 \\
4 \\
5 \\
3\end{array}$ & $\begin{array}{r}250 \\
\mathrm{~N} \\
46 \\
121 \\
47 \\
22 \\
8 \\
6\end{array}$ & $\begin{array}{r}212 \\
\mathrm{~N} \\
33 \\
79 \\
54 \\
18 \\
9 \\
19\end{array}$ \\
\hline $\begin{array}{l}\text { S. Atlantic } \\
\text { Delaware } \\
\text { District of Columbia } \\
\text { Florida } \\
\text { Georgia } \\
\text { Maryland } \\
\text { North Carolina } \\
\text { South Carolina } \\
\text { Virginia } \\
\text { West Virginia }\end{array}$ & $\begin{array}{l}9 \\
- \\
-2 \\
2 \\
5 \\
3 \\
- \\
-\end{array}$ & $\begin{array}{l}7 \\
0 \\
0 \\
2 \\
1 \\
1 \\
1 \\
0 \\
0 \\
0\end{array}$ & $\begin{array}{r}39 \\
2 \\
1 \\
29 \\
6 \\
5 \\
10 \\
2 \\
8 \\
2\end{array}$ & $\begin{array}{r}278 \\
7 \\
-62 \\
59 \\
46 \\
68 \\
6 \\
- \\
-\end{array}$ & $\begin{array}{r}263 \\
6 \\
66 \\
33 \\
50 \\
38 \\
7 \\
61 \\
2\end{array}$ & $\begin{array}{r}43 \\
- \\
33 \\
7 \\
3 \\
- \\
- \\
-\end{array}$ & $\begin{array}{r}53 \\
0 \\
0 \\
26 \\
16 \\
2 \\
1 \\
1 \\
1 \\
0\end{array}$ & $\begin{array}{r}122 \\
2 \\
2 \\
66 \\
38 \\
10 \\
22 \\
9 \\
8 \\
2\end{array}$ & $\begin{array}{r}1,756 \\
7 \\
10 \\
863 \\
571 \\
86 \\
109 \\
64 \\
44 \\
2\end{array}$ & $\begin{array}{r}1,388 \\
10 \\
8 \\
676 \\
338 \\
57 \\
133 \\
72 \\
94 \\
\end{array}$ & $\begin{array}{l}17 \\
\overline{-} \\
8 \\
6 \\
2 \\
- \\
- \\
-1\end{array}$ & $\begin{array}{r}22 \\
0 \\
0 \\
6 \\
4 \\
4 \\
1 \\
1 \\
2 \\
0\end{array}$ & $\begin{array}{r}43 \\
2 \\
2 \\
16 \\
11 \\
12 \\
26 \\
6 \\
11 \\
6\end{array}$ & $\begin{array}{r}857 \\
8 \\
9 \\
212 \\
167 \\
160 \\
126 \\
50 \\
102 \\
23\end{array}$ & $\begin{array}{r}672 \\
5 \\
7 \\
171 \\
143 \\
130 \\
96 \\
29 \\
69 \\
22\end{array}$ \\
\hline $\begin{array}{l}\text { E.S. Central } \\
\text { Alabama§ } \\
\text { Kentucky } \\
\text { Mississippi } \\
\text { Tennessee }^{\S}\end{array}$ & $\begin{array}{l}\frac{6}{4} \\
-\end{array}$ & $\begin{array}{l}2 \\
0 \\
1 \\
0 \\
0\end{array}$ & $\begin{array}{r}14 \\
5 \\
8 \\
1 \\
4\end{array}$ & $\begin{array}{r}131 \\
19 \\
49 \\
24\end{array}$ & $\begin{array}{r}114 \\
23 \\
42 \\
5 \\
44\end{array}$ & $\begin{array}{r}8 \\
4 \\
2 \\
2\end{array}$ & $\begin{array}{r}13 \\
3 \\
5 \\
1 \\
3\end{array}$ & $\begin{array}{r}31 \\
14 \\
12 \\
6 \\
11\end{array}$ & $\begin{array}{r}410 \\
126 \\
160 \\
37 \\
87\end{array}$ & $\begin{array}{r}941 \\
182 \\
223 \\
66 \\
470\end{array}$ & $\frac{1}{\mathrm{~N}}$ & $\begin{array}{l}3 \\
0 \\
0 \\
0 \\
3\end{array}$ & $\begin{array}{r}11 \\
0 \\
5 \\
0 \\
9\end{array}$ & $\begin{array}{r}155 \\
N \\
33 \\
-122\end{array}$ & $\begin{array}{r}134 \\
N \\
26 \\
108\end{array}$ \\
\hline $\begin{array}{l}\text { W.S. Central } \\
\text { Arkansas } \\
\text { Louisiana } \\
\text { Oklahoma } \\
\text { Texas }\end{array}$ & $\frac{1}{-}$ & $\begin{array}{l}1 \\
0 \\
0 \\
0 \\
1\end{array}$ & $\begin{array}{r}52 \\
2 \\
1 \\
8 \\
44\end{array}$ & $\begin{array}{l}21 \\
10 \\
11 \\
51\end{array}$ & $\begin{array}{r}67 \\
9 \\
18 \\
17 \\
23\end{array}$ & $\begin{array}{r}12 \\
3 \\
9 \\
-\end{array}$ & $\begin{array}{r}27 \\
1 \\
0 \\
3 \\
23\end{array}$ & $\begin{array}{r}596 \\
7 \\
7 \\
286 \\
308\end{array}$ & $\begin{array}{r}660 \\
66 \\
32 \\
87 \\
475\end{array}$ & $\begin{array}{r}2,450 \\
45 \\
110 \\
486 \\
1,809\end{array}$ & $\begin{array}{l}6 \\
- \\
2 \\
4\end{array}$ & $\begin{array}{l}7 \\
0 \\
0 \\
2 \\
4\end{array}$ & $\begin{array}{r}58 \\
5 \\
1 \\
14 \\
43\end{array}$ & $\begin{array}{r}284 \\
23 \\
2 \\
77 \\
182\end{array}$ & $\begin{array}{r}234 \\
14 \\
5 \\
86 \\
129\end{array}$ \\
\hline $\begin{array}{l}\text { Mountain } \\
\text { Arizona } \\
\text { Colorado } \\
\text { Idaho§ } \\
\text { Montana } \\
\text { Nevada§ } \\
\text { New Mexico§ } \\
\text { Utah } \\
\text { Wyoming }\end{array}$ & $\begin{array}{r}5 \\
3 \\
1 \\
3 \\
- \\
- \\
12 \\
-\end{array}$ & $\begin{array}{l}5 \\
1 \\
1 \\
1 \\
0 \\
0 \\
0 \\
1 \\
0\end{array}$ & $\begin{array}{r}13 \\
8 \\
6 \\
7 \\
1 \\
3 \\
2 \\
10 \\
3\end{array}$ & $\begin{array}{r}164 \\
63 \\
48 \\
44 \\
9 \\
9 \\
4 \\
78 \\
13\end{array}$ & $\begin{array}{r}201 \\
20 \\
52 \\
26 \\
13 \\
15 \\
19 \\
49 \\
7\end{array}$ & $\begin{array}{l}29 \\
21 \\
7 \\
- \\
- \\
-1 \\
-\end{array}$ & $\begin{array}{r}22 \\
12 \\
3 \\
0 \\
0 \\
1 \\
2 \\
1 \\
0\end{array}$ & $\begin{array}{r}47 \\
29 \\
18 \\
4 \\
1 \\
8 \\
8 \\
10 \\
4 \\
1\end{array}$ & $\begin{array}{r}670 \\
392 \\
102 \\
14 \\
5 \\
30 \\
79 \\
45 \\
3\end{array}$ & $\begin{array}{r}515 \\
266 \\
80 \\
10 \\
5 \\
41 \\
79 \\
32 \\
2\end{array}$ & $\begin{array}{l}4 \\
1 \\
3 \\
- \\
- \\
- \\
-\end{array}$ & $\begin{array}{r}12 \\
6 \\
3 \\
0 \\
0 \\
0 \\
1 \\
1 \\
0\end{array}$ & $\begin{array}{r}78 \\
57 \\
8 \\
2 \\
0 \\
6 \\
7 \\
7 \\
1\end{array}$ & $\begin{array}{r}500 \\
267 \\
108 \\
7 \\
- \\
- \\
58 \\
57 \\
3\end{array}$ & $\begin{array}{r}438 \\
181 \\
139 \\
2 \\
2 \\
2 \\
66 \\
45 \\
3\end{array}$ \\
\hline $\begin{array}{l}\text { Pacific } \\
\text { Alaska } \\
\text { California } \\
\text { Hawaii } \\
\text { Oregon } \\
\text { Washington }\end{array}$ & $\begin{array}{l}\frac{3}{3} \\
\frac{2}{2} \\
-\end{array}$ & $\begin{array}{l}7 \\
0 \\
4 \\
0 \\
2 \\
2\end{array}$ & $\begin{array}{r}55 \\
1 \\
18 \\
2 \\
47 \\
32\end{array}$ & $\begin{array}{r}207 \\
-134 \\
11 \\
64 \\
62\end{array}$ & $\begin{array}{r}210 \\
9 \\
86 \\
9 \\
59 \\
47\end{array}$ & $\begin{array}{l}\frac{44}{41} \\
\frac{3}{-}\end{array}$ & $\begin{array}{r}39 \\
0 \\
32 \\
1 \\
1 \\
2\end{array}$ & $\begin{array}{r}148 \\
2 \\
104 \\
4 \\
31 \\
43\end{array}$ & $\begin{array}{r}1,200 \\
8 \\
984 \\
30 \\
97 \\
81\end{array}$ & $\begin{array}{r}1,366 \\
11 \\
1,152 \\
26 \\
98 \\
79\end{array}$ & $\begin{array}{l}- \\
\overline{-} \\
\bar{N} \\
\mathrm{~N}\end{array}$ & $\begin{array}{l}2 \\
0 \\
0 \\
2 \\
0 \\
0\end{array}$ & $\begin{array}{l}9 \\
0 \\
0 \\
9 \\
0 \\
0\end{array}$ & $\begin{array}{l}76 \\
- \\
76 \\
N \\
N\end{array}$ & $\begin{array}{l}73 \\
- \\
73 \\
N \\
N\end{array}$ \\
\hline $\begin{array}{l}\text { American Samoa } \\
\text { C.N.M.I. } \\
\text { Guam } \\
\text { Puerto Rico } \\
\text { U.S. Virgin Islands }\end{array}$ & $\begin{array}{l}U \\
\frac{U}{-} \\
-\end{array}$ & $\begin{array}{l}0 \\
0 \\
0 \\
0 \\
0\end{array}$ & $\begin{array}{l}0 \\
0 \\
0 \\
0 \\
0\end{array}$ & $\begin{array}{l}U \\
U \\
- \\
-\end{array}$ & $\begin{array}{l}U \\
\frac{U}{2} \\
\end{array}$ & $\begin{array}{l}U \\
U \\
- \\
-\end{array}$ & $\begin{array}{l}0 \\
0 \\
0 \\
0 \\
0\end{array}$ & $\begin{array}{l}2 \\
0 \\
3 \\
2 \\
0\end{array}$ & $\frac{U}{\frac{U}{10}}$ & $\begin{array}{r}5 \\
U \\
12 \\
4 \\
-\end{array}$ & $\frac{U}{\mathrm{U}}$ & $\begin{array}{l}0 \\
0 \\
0 \\
0 \\
0\end{array}$ & $\begin{array}{l}0 \\
0 \\
0 \\
0 \\
0\end{array}$ & $\frac{U}{U}$ & $\frac{U}{\mathrm{U}}$ \\
\hline
\end{tabular}

C.N.M.I.: Commonwealth of Northern Mariana Islands.

U: Unavailable. - No reported cases. N: Not notifiable. Cum: Cumulative year-to-date counts.

Med: Median.

Max: Maximum.

* Incidence data for reporting years 2005 and 2006 are provisional.

Includes E. coli O157:H7; Shiga toxin positive, serogroup non-0157; and Shiga toxin positive, not serogrouped.

$\S$ Contains data reported through the National Electronic Disease Surveillance System (NEDSS). 
TABLE II. (Continued) Provisional cases of selected notifiable diseases, United States, weeks ending September 9, 2006, and September 10, 2005 (36th Week)*

\begin{tabular}{|c|c|c|c|c|c|c|c|c|c|c|c|c|c|c|c|}
\hline \multirow[b]{3}{*}{ Reporting area } & \multicolumn{5}{|c|}{$\begin{array}{c}\text { Streptococcus pneumoniae, invasive disease } \\
\text { Drug resistant, all ages }\end{array}$} & \multicolumn{5}{|c|}{ Syphilis, primary and secondary } & \multicolumn{5}{|c|}{ Varicella (chickenpox) } \\
\hline & \multirow{2}{*}{$\begin{array}{c}\text { Current } \\
\text { week }\end{array}$} & \multicolumn{2}{|c|}{$\begin{array}{l}\text { Previous } \\
52 \text { weeks }\end{array}$} & \multirow{2}{*}{$\begin{array}{l}\text { Cum } \\
2006\end{array}$} & \multirow{2}{*}{$\begin{array}{l}\text { Cum } \\
2005\end{array}$} & \multirow{2}{*}{$\begin{array}{c}\text { Current } \\
\text { week }\end{array}$} & \multicolumn{2}{|c|}{$\begin{array}{l}\text { Previous } \\
52 \text { weeks }\end{array}$} & \multirow{2}{*}{$\begin{array}{l}\text { Cum } \\
2006\end{array}$} & \multirow{2}{*}{$\begin{array}{l}\text { Cum } \\
2005\end{array}$} & \multirow{2}{*}{$\begin{array}{c}\text { Current } \\
\text { week }\end{array}$} & \multicolumn{2}{|c|}{$\begin{array}{l}\text { Previous } \\
52 \text { weeks }\end{array}$} & \multirow{2}{*}{$\begin{array}{l}\text { Cum } \\
2006\end{array}$} & \multirow{2}{*}{$\begin{array}{l}\text { Cum } \\
2005 \\
\end{array}$} \\
\hline & & Med & $\operatorname{Max}$ & & & & Med & $\operatorname{Max}$ & & & & Med & Max & & \\
\hline United States & 23 & 51 & 334 & 1,807 & 1,887 & 86 & 170 & 334 & 5,930 & 5,764 & 160 & 801 & 3,204 & 29,206 & 19,411 \\
\hline $\begin{array}{l}\text { New England } \\
\text { Connecticut } \\
\text { Maine }^{\dagger} \\
\text { Massachusetts } \\
\text { New Hampshire } \\
\text { Rhode Island } \\
\text { Vermont }^{\dagger}\end{array}$ & $\begin{array}{l}1 \\
\frac{U}{-} \\
\frac{1}{-}\end{array}$ & $\begin{array}{l}1 \\
0 \\
0 \\
0 \\
0 \\
0 \\
0\end{array}$ & $\begin{array}{r}24 \\
7 \\
2 \\
6 \\
0 \\
11 \\
2\end{array}$ & $\begin{array}{r}28 \\
U \\
8 \\
- \\
10 \\
10\end{array}$ & $\begin{array}{r}167 \\
69 \\
\mathrm{~N} \\
75 \\
14 \\
9\end{array}$ & $\begin{array}{r}3 \\
1 \\
-1 \\
1 \\
-\end{array}$ & $\begin{array}{l}4 \\
0 \\
0 \\
2 \\
0 \\
0 \\
0\end{array}$ & $\begin{array}{r}17 \\
11 \\
2 \\
6 \\
2 \\
6 \\
1\end{array}$ & $\begin{array}{r}147 \\
30 \\
7 \\
89 \\
12 \\
7 \\
2\end{array}$ & $\begin{array}{r}141 \\
30 \\
1 \\
88 \\
11 \\
10 \\
1\end{array}$ & $\begin{array}{l}2 \\
\\
- \\
\\
2\end{array}$ & $\begin{array}{r}44 \\
0 \\
5 \\
3 \\
6 \\
0 \\
12\end{array}$ & $\begin{array}{r}144 \\
58 \\
20 \\
54 \\
47 \\
0 \\
50\end{array}$ & $\begin{array}{r}1,093 \\
U \\
151 \\
94 \\
347 \\
-1 \\
501\end{array}$ & $\begin{array}{r}3,743 \\
1,074 \\
221 \\
1,702 \\
209 \\
-537\end{array}$ \\
\hline $\begin{array}{l}\text { Mid. Atlantic } \\
\text { New Jersey } \\
\text { New York (Upstate) } \\
\text { New York City } \\
\text { Pennsylvania }\end{array}$ & $\begin{array}{r}1 \\
N \\
1 \\
U \\
-\end{array}$ & $\begin{array}{l}3 \\
0 \\
1 \\
0 \\
2\end{array}$ & $\begin{array}{r}15 \\
0 \\
10 \\
0 \\
9\end{array}$ & $\begin{array}{r}118 \\
N \\
43 \\
U \\
75\end{array}$ & $\begin{array}{r}164 \\
N \\
64 \\
U \\
100\end{array}$ & $\begin{array}{l}7 \\
3 \\
2 \\
2\end{array}$ & $\begin{array}{r}21 \\
3 \\
2 \\
10 \\
5\end{array}$ & $\begin{array}{r}35 \\
7 \\
14 \\
23 \\
9\end{array}$ & $\begin{array}{r}732 \\
115 \\
98 \\
340 \\
179\end{array}$ & $\begin{array}{r}723 \\
97 \\
53 \\
444 \\
129\end{array}$ & $\frac{21}{-}$ & $\begin{array}{r}105 \\
0 \\
0 \\
0 \\
105\end{array}$ & $\begin{array}{r}183 \\
0 \\
0 \\
0 \\
183\end{array}$ & $\begin{array}{r}\frac{3,353}{-} \\
\frac{3,353}{-}\end{array}$ & $\begin{array}{r}3,277 \\
- \\
\frac{-}{3,277}\end{array}$ \\
\hline $\begin{array}{l}\text { E.N. Central } \\
\text { Illinois } \\
\text { Indiana } \\
\text { Michigan } \\
\text { Ohio } \\
\text { Wisconsin }\end{array}$ & $\begin{array}{r}\frac{9}{1} \\
\frac{1}{8} \\
\mathrm{~N}\end{array}$ & $\begin{array}{r}11 \\
0 \\
2 \\
0 \\
6 \\
0\end{array}$ & $\begin{array}{r}41 \\
3 \\
21 \\
4 \\
4 \\
32 \\
0\end{array}$ & $\begin{array}{r}429 \\
15 \\
115 \\
17 \\
282 \\
\mathrm{~N}\end{array}$ & $\begin{array}{r}475 \\
23 \\
147 \\
30 \\
275 \\
\mathrm{~N}\end{array}$ & $\begin{array}{r}8 \\
2 \\
1 \\
4 \\
1 \\
-\end{array}$ & $\begin{array}{r}17 \\
8 \\
1 \\
2 \\
4 \\
1\end{array}$ & $\begin{array}{r}38 \\
23 \\
4 \\
19 \\
8 \\
8 \\
4\end{array}$ & $\begin{array}{r}620 \\
292 \\
59 \\
85 \\
144 \\
40\end{array}$ & $\begin{array}{r}623 \\
349 \\
46 \\
56 \\
149 \\
23\end{array}$ & $\begin{array}{l}34 \\
\frac{-}{6} \\
28 \\
-\end{array}$ & $\begin{array}{r}237 \\
1 \\
0 \\
102 \\
82 \\
12\end{array}$ & $\begin{array}{r}586 \\
6 \\
475 \\
174 \\
420 \\
52\end{array}$ & $\begin{array}{r}10,715 \\
38 \\
475 \\
3,087 \\
6,526 \\
589\end{array}$ & $\begin{array}{r}4,066 \\
71 \\
251 \\
2,432 \\
992 \\
320\end{array}$ \\
\hline $\begin{array}{l}\text { W.N. Central } \\
\text { lowa } \\
\text { Kansas } \\
\text { Minnesota } \\
\text { Missouri } \\
\text { Nebraska }^{\dagger} \\
\text { North Dakota } \\
\text { South Dakota }\end{array}$ & $\begin{array}{l}\bar{N} \\
N \\
- \\
- \\
-\end{array}$ & $\begin{array}{l}1 \\
0 \\
0 \\
0 \\
1 \\
0 \\
0 \\
0\end{array}$ & $\begin{array}{r}191 \\
0 \\
0 \\
191 \\
3 \\
0 \\
1 \\
1\end{array}$ & $\begin{array}{l}33 \\
N \\
N \\
-32 \\
- \\
-1\end{array}$ & $\begin{array}{r}31 \\
\mathrm{~N} \\
\mathrm{~N} \\
25 \\
2 \\
1 \\
3\end{array}$ & $\begin{array}{l}3 \\
- \\
- \\
\frac{2}{-} \\
-1\end{array}$ & $\begin{array}{l}5 \\
0 \\
0 \\
1 \\
3 \\
0 \\
0 \\
0\end{array}$ & $\begin{array}{r}10 \\
3 \\
2 \\
3 \\
8 \\
1 \\
1 \\
3\end{array}$ & $\begin{array}{r}180 \\
11 \\
16 \\
21 \\
121 \\
3 \\
8\end{array}$ & $\begin{array}{r}178 \\
6 \\
15 \\
52 \\
100 \\
4 \\
-1\end{array}$ & $\begin{array}{r}10 \\
\mathrm{~N} \\
2 \\
- \\
- \\
8 \\
\end{array}$ & $\begin{array}{r}22 \\
0 \\
0 \\
0 \\
17 \\
0 \\
0 \\
1\end{array}$ & $\begin{array}{r}84 \\
0 \\
8 \\
0 \\
82 \\
0 \\
25 \\
12\end{array}$ & $\begin{array}{r}1,043 \\
\mathrm{~N} \\
17 \\
- \\
945 \\
-44 \\
37\end{array}$ & $\begin{array}{r}300 \\
\mathrm{~N} \\
- \\
208 \\
- \\
13 \\
79\end{array}$ \\
\hline $\begin{array}{l}\text { S. Atlantic } \\
\text { Delaware } \\
\text { District of Columbia } \\
\text { Florida } \\
\text { Georgia } \\
\text { Maryland }^{\dagger} \\
\text { North Carolina } \\
\text { South Carolina }^{\dagger} \\
\text { Virginia }^{\dagger} \\
\text { West Virginia }\end{array}$ & $\begin{array}{l}\frac{10}{-} \\
\frac{6}{4} \\
\frac{\mathrm{N}}{\mathrm{N}} \\
-\end{array}$ & $\begin{array}{r}26 \\
0 \\
0 \\
13 \\
8 \\
0 \\
0 \\
0 \\
0 \\
1\end{array}$ & $\begin{array}{r}53 \\
2 \\
3 \\
36 \\
29 \\
0 \\
0 \\
0 \\
0 \\
14\end{array}$ & $\begin{array}{r}967 \\
-21 \\
531 \\
322 \\
\frac{\mathrm{N}}{-} \\
\mathrm{N} \\
93\end{array}$ & $\begin{array}{r}780 \\
1 \\
13 \\
422 \\
249 \\
\mathrm{~N} \\
\mathrm{~N} \\
95\end{array}$ & $\begin{array}{l}23 \\
\frac{-}{13} \\
\frac{2}{2} \\
\frac{7}{1} \\
-\end{array}$ & $\begin{array}{r}42 \\
0 \\
2 \\
15 \\
7 \\
5 \\
5 \\
1 \\
3 \\
0\end{array}$ & $\begin{array}{r}186 \\
2 \\
9 \\
29 \\
147 \\
19 \\
17 \\
7 \\
12 \\
1\end{array}$ & $\begin{array}{r}1,385 \\
16 \\
79 \\
515 \\
205 \\
199 \\
211 \\
47 \\
110 \\
3\end{array}$ & $\begin{array}{r}1,369 \\
8 \\
69 \\
476 \\
273 \\
219 \\
188 \\
43 \\
91 \\
2\end{array}$ & $\begin{array}{l}6 \\
- \\
- \\
- \\
\frac{2}{4}\end{array}$ & $\begin{array}{r}90 \\
1 \\
0 \\
0 \\
0 \\
0 \\
0 \\
16 \\
30 \\
26\end{array}$ & $\begin{array}{r}860 \\
5 \\
5 \\
0 \\
0 \\
0 \\
0 \\
52 \\
812 \\
70\end{array}$ & $\begin{array}{r}3,102 \\
46 \\
25 \\
- \\
- \\
- \\
- \\
759 \\
1,217 \\
1,055\end{array}$ & $\begin{array}{r}1,463 \\
22 \\
24 \\
- \\
- \\
- \\
- \\
384 \\
314 \\
719\end{array}$ \\
\hline $\begin{array}{l}\text { E.S. Central } \\
\text { Alabama }^{\dagger} \\
\text { Kentucky } \\
\text { Mississippi } \\
\text { Tennessee }^{\dagger}\end{array}$ & $\begin{array}{r}2 \\
N \\
1 \\
1\end{array}$ & $\begin{array}{l}3 \\
0 \\
0 \\
0 \\
3\end{array}$ & $\begin{array}{r}13 \\
0 \\
5 \\
0 \\
13\end{array}$ & $\begin{array}{r}143 \\
N \\
28 \\
-115\end{array}$ & $\begin{array}{r}131 \\
N \\
24 \\
1 \\
106\end{array}$ & $\begin{array}{r}10 \\
7 \\
- \\
3\end{array}$ & $\begin{array}{r}13 \\
4 \\
1 \\
0 \\
5\end{array}$ & $\begin{array}{r}24 \\
18 \\
8 \\
6 \\
13\end{array}$ & $\begin{array}{r}477 \\
211 \\
48 \\
42 \\
176\end{array}$ & $\begin{array}{r}315 \\
105 \\
31 \\
37 \\
142\end{array}$ & $\begin{array}{r}1 \\
1 \\
N \\
N\end{array}$ & $\begin{array}{l}0 \\
0 \\
0 \\
0 \\
0\end{array}$ & $\begin{array}{r}70 \\
70 \\
0 \\
1 \\
0\end{array}$ & $\begin{array}{r}89 \\
88 \\
\mathrm{~N} \\
1 \\
\mathrm{~N}\end{array}$ & $\begin{array}{r}36 \\
36 \\
N \\
N\end{array}$ \\
\hline $\begin{array}{l}\text { W.S. Central } \\
\text { Arkansas } \\
\text { Louisiana } \\
\text { Oklahoma } \\
\text { Texas }^{\dagger}\end{array}$ & $\begin{array}{l}- \\
\frac{-}{N} \\
N\end{array}$ & $\begin{array}{l}0 \\
0 \\
0 \\
0 \\
0\end{array}$ & $\begin{array}{l}4 \\
3 \\
4 \\
0 \\
0\end{array}$ & $\begin{array}{r}14 \\
11 \\
3 \\
N \\
N\end{array}$ & $\begin{array}{r}99 \\
12 \\
87 \\
N \\
N\end{array}$ & $\begin{array}{r}26 \\
4 \\
3 \\
4 \\
15\end{array}$ & $\begin{array}{r}26 \\
1 \\
4 \\
1 \\
21\end{array}$ & $\begin{array}{r}44 \\
6 \\
17 \\
6 \\
39\end{array}$ & $\begin{array}{r}1,047 \\
52 \\
154 \\
51 \\
790\end{array}$ & $\begin{array}{r}859 \\
32 \\
192 \\
28 \\
607\end{array}$ & $\begin{array}{r}67 \\
2 \\
- \\
65\end{array}$ & $\begin{array}{r}181 \\
7 \\
0 \\
0 \\
165\end{array}$ & $\begin{array}{r}1,757 \\
110 \\
8 \\
0 \\
1,647\end{array}$ & $\begin{array}{r}7,922 \\
587 \\
43 \\
7,292\end{array}$ & $\begin{array}{r}\frac{4,667}{108} \\
\frac{-}{4,559}\end{array}$ \\
\hline $\begin{array}{l}\text { Mountain } \\
\text { Arizona } \\
\text { Colorado } \\
\text { Idaho }^{\dagger} \\
\text { Montana } \\
\text { Nevada }^{\dagger} \\
\text { New Mexico } \\
\text { Utah } \\
\text { Wyoming }\end{array}$ & $\begin{array}{l}\bar{N} \\
N \\
N \\
- \\
- \\
- \\
-\end{array}$ & $\begin{array}{l}2 \\
0 \\
0 \\
0 \\
0 \\
0 \\
0 \\
0 \\
1\end{array}$ & $\begin{array}{r}27 \\
0 \\
0 \\
0 \\
1 \\
27 \\
1 \\
8 \\
3\end{array}$ & $\begin{array}{r}75 \\
N \\
N \\
N \\
4 \\
1 \\
33 \\
37\end{array}$ & $\begin{array}{r}40 \\
N \\
N \\
N \\
2 \\
\frac{1}{17} \\
21\end{array}$ & $\begin{array}{l}2 \\
2 \\
- \\
- \\
- \\
- \\
-\end{array}$ & $\begin{array}{l}7 \\
4 \\
1 \\
0 \\
0 \\
1 \\
1 \\
0 \\
0\end{array}$ & $\begin{array}{r}24 \\
16 \\
3 \\
1 \\
1 \\
12 \\
5 \\
1 \\
0\end{array}$ & $\begin{array}{r}286 \\
131 \\
30 \\
2 \\
1 \\
71 \\
45 \\
6 \\
-\end{array}$ & $\begin{array}{r}298 \\
107 \\
33 \\
20 \\
5 \\
87 \\
39 \\
7 \\
-\end{array}$ & $\begin{array}{l}\frac{19}{16} \\
- \\
- \\
\frac{3}{-}\end{array}$ & $\begin{array}{r}52 \\
0 \\
33 \\
0 \\
0 \\
0 \\
3 \\
11 \\
0\end{array}$ & $\begin{array}{r}138 \\
0 \\
76 \\
0 \\
0 \\
2 \\
34 \\
55 \\
8\end{array}$ & $\begin{array}{r}1,889 \\
- \\
996 \\
- \\
4 \\
297 \\
560 \\
32\end{array}$ & $\begin{array}{r}1,859 \\
1,263 \\
- \\
- \\
- \\
164 \\
383 \\
49\end{array}$ \\
\hline $\begin{array}{l}\text { Pacific } \\
\text { Alaska } \\
\text { California } \\
\text { Hawaii } \\
\text { Oregon }^{\dagger} \\
\text { Washington }\end{array}$ & $\begin{array}{l}-\bar{T} \\
\frac{\mathrm{N}}{\mathrm{N}} \\
\mathrm{N}\end{array}$ & $\begin{array}{l}0 \\
0 \\
0 \\
0 \\
0 \\
0\end{array}$ & $\begin{array}{l}0 \\
0 \\
0 \\
0 \\
0 \\
0\end{array}$ & $\begin{array}{l}- \\
\frac{N}{N} \\
N\end{array}$ & $\begin{array}{l}- \\
\frac{N}{N} \\
\frac{N}{N}\end{array}$ & $\begin{array}{l}\frac{4}{2} \\
\frac{-}{2}\end{array}$ & $\begin{array}{r}31 \\
0 \\
28 \\
0 \\
0 \\
2\end{array}$ & $\begin{array}{r}49 \\
4 \\
39 \\
2 \\
2 \\
6 \\
11\end{array}$ & $\begin{array}{r}1,056 \\
6 \\
893 \\
12 \\
13 \\
132\end{array}$ & $\begin{array}{r}1,258 \\
6 \\
1,127 \\
8 \\
21 \\
96\end{array}$ & $\begin{array}{l}- \\
\overline{-} \\
\mathrm{N} \\
\mathrm{N} \\
\mathrm{N}\end{array}$ & $\begin{array}{l}0 \\
0 \\
0 \\
0 \\
0 \\
0\end{array}$ & $\begin{array}{l}0 \\
0 \\
0 \\
0 \\
0 \\
0\end{array}$ & $\begin{array}{l}- \\
- \\
N \\
N \\
N\end{array}$ & $\begin{array}{l}- \\
- \\
N \\
N \\
N\end{array}$ \\
\hline $\begin{array}{l}\text { American Samoa } \\
\text { C.N.M.I. } \\
\text { Guam } \\
\text { Puerto Rico } \\
\text { U.S. Virgin Islands }\end{array}$ & $\begin{array}{l}- \\
\bar{N} \\
-\end{array}$ & $\begin{array}{l}0 \\
0 \\
0 \\
0 \\
0\end{array}$ & $\begin{array}{l}0 \\
0 \\
0 \\
0 \\
0\end{array}$ & $\begin{array}{l}- \\
\bar{N} \\
-\end{array}$ & $\frac{-}{-}$ & $\begin{array}{l}U \\
U \\
- \\
-\end{array}$ & $\begin{array}{l}0 \\
0 \\
0 \\
3 \\
0\end{array}$ & $\begin{array}{r}0 \\
0 \\
0 \\
10 \\
0\end{array}$ & $\frac{U}{\frac{U}{86}}$ & $\begin{array}{r}U \\
U \\
3 \\
152 \\
\end{array}$ & $\frac{U}{\frac{U}{5}}$ & $\begin{array}{l}0 \\
0 \\
3 \\
7 \\
0\end{array}$ & $\begin{array}{r}0 \\
0 \\
12 \\
47 \\
0\end{array}$ & $\begin{array}{r}U \\
\frac{U}{236} \\
\end{array}$ & $\begin{array}{r}U \\
U \\
380 \\
515 \\
-\end{array}$ \\
\hline
\end{tabular}

C.N.M.I.: Commonwealth of Northern Mariana Islands.

U: Unavailable. $\quad$-: No reported cases. $\quad \mathrm{N}$ : Not notifiable.

Cum: Cumulative year-to-date counts.

Med: Median

Max: Maximum.

* Incidence data for reporting years 2005 and 2006 are provisional.

Contains data reported through the National Electronic Disease Surveillance System (NEDSS). 
TABLE II. (Continued) Provisional cases of selected notifiable diseases, United States, weeks ending September 9, 2006, and September 10, 2005 (36th Week)*

\begin{tabular}{|c|c|c|c|c|c|c|c|c|c|c|}
\hline \multirow[b]{4}{*}{ Reporting area } & \multicolumn{10}{|c|}{ West Nile virus disease $^{\dagger}$} \\
\hline & \multicolumn{5}{|c|}{ Neuroinvasive } & \multicolumn{5}{|c|}{ Non-neuroinvasive } \\
\hline & \multirow{2}{*}{$\begin{array}{c}\text { Current } \\
\text { week }\end{array}$} & \multicolumn{2}{|c|}{$\begin{array}{l}\text { Previous } \\
52 \text { weeks }\end{array}$} & \multirow{2}{*}{$\begin{array}{l}\text { Cum } \\
2006\end{array}$} & \multirow{2}{*}{$\begin{array}{l}\text { Cum } \\
2005\end{array}$} & & & & Cum & Cum \\
\hline & & Med & Max & & & week & Med & Max & 2006 & 2005 \\
\hline United States & - & 1 & 115 & 448 & 971 & - & 0 & 229 & 785 & 1,346 \\
\hline New England & - & 0 & 3 & 4 & 7 & - & 0 & 2 & 2 & - \\
\hline Connecticut & - & 0 & 2 & 4 & 2 & - & 0 & 1 & 2 & - \\
\hline Maine ${ }^{\S}$ & - & 0 & 0 & - & - & - & 0 & 0 & - & - \\
\hline Massachusetts & - & 0 & 3 & - & 4 & - & 0 & 1 & - & - \\
\hline New Hampshire & - & 0 & 0 & - & - & - & 0 & 0 & - & - \\
\hline Rhode Island & - & 0 & 0 & - & 1 & - & 0 & 0 & - & - \\
\hline Vermont ${ }^{\S}$ & - & 0 & 0 & - & - & - & 0 & 0 & - & - \\
\hline Mid. Atlantic & - & 0 & 8 & 5 & 31 & - & 0 & 3 & 2 & 17 \\
\hline New Jersey & - & 0 & 1 & - & 1 & - & 0 & 2 & 1 & - \\
\hline New York (Upstate) & - & 0 & 4 & - & 11 & - & 0 & 1 & - & 4 \\
\hline New York City & - & 0 & 2 & 1 & 6 & - & 0 & 0 & - & 3 \\
\hline Pennsylvania & - & 0 & 3 & 4 & 13 & - & 0 & 1 & 1 & 10 \\
\hline E.N. Central & - & 0 & 28 & 39 & 199 & - & 0 & 15 & 9 & 102 \\
\hline Illinois & - & 0 & 12 & 31 & 108 & - & 0 & 9 & 7 & 81 \\
\hline Indiana & - & 0 & 2 & 1 & 7 & - & 0 & 1 & - & 1 \\
\hline Michigan & - & 0 & 10 & 3 & 39 & - & 0 & 3 & - & 6 \\
\hline Ohio & - & 0 & 5 & 2 & 40 & - & 0 & 2 & 1 & 11 \\
\hline Wisconsin & - & 0 & 3 & 2 & 5 & - & 0 & 2 & 1 & 3 \\
\hline W.N. Central & - & 0 & 22 & 92 & 125 & - & 0 & 48 & 192 & 400 \\
\hline lowa & - & 0 & 3 & 5 & 7 & - & 0 & 4 & 4 & 13 \\
\hline Kansas & - & 0 & 3 & 12 & 7 & - & 0 & 2 & 6 & $\mathrm{~N}$ \\
\hline Minnesota & - & 0 & 5 & 17 & 16 & - & 0 & 7 & 25 & 18 \\
\hline Missouri & - & 0 & 5 & 12 & 10 & - & 0 & 3 & 3 & 11 \\
\hline Nebraska§ & - & 0 & 6 & 14 & 40 & - & 0 & 13 & 41 & 110 \\
\hline North Dakota & - & 0 & 4 & 10 & 12 & - & 0 & 19 & 67 & 68 \\
\hline South Dakota & - & 0 & 7 & 22 & 33 & - & 0 & 17 & 46 & 180 \\
\hline S. Atlantic & - & 0 & 6 & 5 & 22 & - & 0 & 3 & - & 16 \\
\hline Delaware & - & 0 & 0 & - & 1 & - & 0 & 0 & - & - \\
\hline District of Columbia & - & 0 & 1 & - & 1 & - & 0 & 1 & - & - \\
\hline $\begin{array}{l}\text { Florida } \\
\text { Fisila }\end{array}$ & - & 0 & 2 & 2 & 8 & - & 0 & 0 & - & 11 \\
\hline Georgia & - & 0 & 3 & 2 & 3 & - & 0 & 3 & - & 2 \\
\hline Maryland $\$$ & - & 0 & 1 & - & 4 & - & 0 & 0 & - & 1 \\
\hline North Carolina & - & 0 & 0 & - & 2 & - & 0 & 1 & - & 2 \\
\hline South Carolina ${ }^{\S}$ & - & 0 & 1 & - & 3 & - & 0 & 0 & - & - \\
\hline Virginia $\$$ & - & 0 & 0 & - & - & - & 0 & 1 & - & - \\
\hline West Virginia & - & 0 & 1 & 1 & - & $\mathrm{N}$ & 0 & 0 & $\mathrm{~N}$ & $\mathrm{~N}$ \\
\hline E.S. Central & - & 0 & 10 & 21 & 45 & - & 0 & 5 & 11 & 24 \\
\hline Alabama ${ }^{\S}$ & - & 0 & 1 & - & 4 & - & 0 & 2 & - & 2 \\
\hline Kentucky & - & 0 & 1 & - & 3 & - & 0 & 0 & - & - \\
\hline Mississippi & - & 0 & 9 & 21 & 26 & - & 0 & 5 & 11 & 21 \\
\hline Tennessee ${ }^{\S}$ & - & 0 & 3 & - & 12 & - & 0 & 1 & - & 1 \\
\hline W.S. Central & - & 0 & 32 & 133 & 190 & - & 0 & 14 & 33 & 121 \\
\hline Arkansas & - & 0 & 3 & 7 & 8 & - & 0 & 2 & 2 & 12 \\
\hline Louisiana & - & 0 & 8 & 29 & 89 & - & 0 & 5 & 14 & 45 \\
\hline Oklahoma & - & 0 & 6 & 12 & 3 & - & 0 & 3 & 1 & 4 \\
\hline Texas $^{\S}$ & - & 0 & 19 & 85 & 90 & - & 0 & 5 & 16 & 60 \\
\hline Mountain & - & 0 & 30 & 114 & 87 & - & 0 & 142 & 423 & 183 \\
\hline Arizona & - & 0 & 8 & 7 & 19 & - & 0 & 8 & 4 & 31 \\
\hline Colorado & - & 0 & 5 & 18 & 15 & - & 0 & 18 & 57 & 70 \\
\hline Idahos ${ }^{\S}$ & - & 0 & 7 & 26 & 3 & - & 0 & 100 & 260 & 9 \\
\hline Montana & - & 0 & 2 & 3 & 8 & - & 0 & 3 & 7 & 16 \\
\hline Nevadas & - & 0 & 9 & 27 & 8 & - & 0 & 10 & 49 & 14 \\
\hline New Mexico§ & - & 0 & 2 & 1 & 14 & - & 0 & 2 & 1 & 13 \\
\hline Utah & - & 0 & 7 & 29 & 19 & - & 0 & 12 & 33 & 26 \\
\hline Wyoming & - & 0 & 2 & 3 & 1 & - & 0 & 5 & 12 & 4 \\
\hline Pacific & - & 0 & 17 & 35 & 265 & - & 0 & 35 & 113 & 483 \\
\hline Alaska & - & 0 & 0 & - & - & - & 0 & 0 & - & - \\
\hline California & - & 0 & 17 & 33 & 264 & - & 0 & 30 & 94 & 477 \\
\hline Hawaii & - & 0 & 0 & - & - & - & 0 & 0 & - & - \\
\hline Oregon ${ }^{\S}$ & - & 0 & 1 & 2 & 1 & - & 0 & 9 & 19 & 6 \\
\hline Washington & - & 0 & 0 & - & - & - & 0 & 0 & - & - \\
\hline American Samoa & $U$ & 0 & 0 & $u$ & $u$ & $U$ & 0 & 0 & $u$ & $U$ \\
\hline C.N.M.I. & $\mathrm{U}$ & 0 & 0 & U & U & U & 0 & 0 & U & $\mathrm{U}$ \\
\hline Guam & - & 0 & 0 & - & - & - & 0 & 0 & - & - \\
\hline Puerto Rico & - & 0 & 0 & - & - & - & 0 & 0 & - & - \\
\hline U.S. Virgin Islands & - & 0 & 0 & - & - & - & 0 & 0 & - & - \\
\hline
\end{tabular}

C.N.M.I.: Commonwealth of Northern Mariana Islands.

U: Unavailable. - $\quad$ No reported cases. N: Not notifiable.

Cum: Cumulative year-to-date counts.

Med: Median.

Max: Maximum

* Incidence data for reporting years 2005 and 2006 are provisional.

Updated weekly from reports to the Division of Vector-Borne Infectious Diseases, National Center for Zoonotic, Vector-Borne, and Enteric Diseases (proposed) (ArboNET

$\S$ Surveillance). 
TABLE III. Deaths in 122 U.S. cities, ${ }^{*}$ week ending September 9, 2006 (36th Week)

\begin{tabular}{|c|c|c|c|c|c|c|c|c|c|c|c|c|c|c|c|}
\hline \multirow[b]{2}{*}{ Reporting Area } & \multicolumn{6}{|c|}{ All causes, by age (years) } & \multirow[b]{2}{*}{$\begin{array}{l}\text { P\&I } \\
\text { Total }\end{array}$} & \multirow[b]{2}{*}{ Reporting Area } & \multicolumn{6}{|c|}{ All causes, by age (years) } & \multirow[b]{2}{*}{$\begin{array}{l}\text { P\&I } \\
\text { Total }\end{array}$} \\
\hline & $\begin{array}{c}\text { All } \\
\text { Ages }\end{array}$ & $\geq 65$ & $45-64$ & $25-44$ & $1-24$ & $<1$ & & & $\begin{array}{c}\text { All } \\
\text { Ages }\end{array}$ & $\geq 65$ & $45-64$ & $25-44$ & $1-24$ & $<1$ & \\
\hline New England & 479 & 325 & 101 & 33 & 14 & 6 & 31 & S. Atlantic & 1,057 & 633 & 263 & 104 & 28 & 29 & 56 \\
\hline Boston, MA & 119 & 71 & 32 & 9 & 6 & 1 & 6 & Atlanta, GA & 136 & 66 & 40 & 24 & 3 & 3 & 4 \\
\hline Bridgeport, CT & 26 & 14 & 5 & 3 & 3 & 1 & 3 & Baltimore, MD & 112 & 67 & 27 & 12 & 2 & 4 & 10 \\
\hline Cambridge, MA & 15 & 12 & 2 & - & 1 & - & 2 & Charlotte, NC & 97 & 52 & 30 & 10 & 3 & 2 & 4 \\
\hline Fall River, MA & 26 & 19 & 6 & 1 & - & - & 3 & Jacksonville, FL & 127 & 76 & 30 & 12 & 8 & 1 & 8 \\
\hline Hartford, CT & 43 & 25 & 12 & 4 & 2 & - & 4 & Miami, FL & 73 & 48 & 17 & 6 & 1 & 1 & 4 \\
\hline Lowell, MA & 36 & 27 & 6 & 3 & - & - & 1 & Norfolk, VA & 56 & 38 & 11 & 3 & 1 & 3 & 2 \\
\hline Lynn, MA & 7 & 4 & 2 & - & 1 & - & 2 & Richmond, VA & 52 & 33 & 13 & 2 & 2 & 2 & 4 \\
\hline New Bedford, MA & 20 & 18 & - & 1 & - & 1 & 1 & Savannah, GA & 51 & 28 & 15 & 3 & 2 & 3 & 1 \\
\hline New Haven, CT & 30 & 21 & 7 & 1 & - & 1 & 3 & St. Petersburg, FL & 41 & 30 & 6 & 2 & - & 3 & 4 \\
\hline Providence, RI & 49 & 41 & 6 & 2 & - & - & 2 & Tampa, FL & 186 & 124 & 38 & 14 & 5 & 5 & 11 \\
\hline Somerville, MA & 4 & 3 & 1 & - & - & - & - & Washington, D.C. & 117 & 63 & 35 & 16 & 1 & 2 & 3 \\
\hline Springfield, MA & 29 & 16 & 7 & 3 & 1 & 2 & 1 & Wilmington, DE & 9 & 8 & 1 & - & - & - & 1 \\
\hline Waterbury, CT & 34 & 25 & 5 & 4 & - & 一 & 1 & E.S. Central & 589 & 385 & 138 & 43 & 11 & 12 & 39 \\
\hline Worcester, MA & 41 & 29 & 10 & 2 & - & - & 2 & Birmingham, AL & 99 & 71 & 19 & 3 & 1 & 5 & 5 \\
\hline Mid. Atlantic & 1,990 & 1,323 & 444 & 140 & 42 & 39 & 96 & Chattanooga, TN & 51 & 34 & 14 & 1 & - & 2 & 3 \\
\hline Albany, NY & 36 & 26 & 7 & 3 & - & - & 3 & Knoxville, TN & 76 & 50 & 20 & 5 & - & 1 & 5 \\
\hline Allentown, PA & 19 & 14 & 5 & - & - & - & 2 & Lexington, $\mathrm{KY}$ & 39 & 27 & 10 & 2 & - & - & 3 \\
\hline Buffalo, NY & 72 & 43 & 19 & 4 & 3 & 3 & 2 & Memphis, TN & 100 & 69 & 21 & 4 & 5 & 1 & 9 \\
\hline Camden, NJ & 39 & 20 & 13 & 2 & 1 & 3 & 2 & Mobile, AL & 70 & 49 & 14 & 4 & 2 & 1 & 3 \\
\hline Elizabeth, NJ & 12 & 7 & 4 & 1 & - & - & - & Montgomery, AL & 36 & 22 & 11 & 3 & - & - & 2 \\
\hline Erie, PA & 42 & 32 & 5 & 2 & - & 3 & 6 & Nashville, TN & 118 & 63 & 29 & 21 & 3 & 2 & 9 \\
\hline Jersey City, NJ & U & U & U & U & $U$ & U & U & W.S. Central & 1,109 & 679 & 278 & 92 & 29 & 31 & 34 \\
\hline New York City, NY & 917 & 637 & 201 & 52 & 14 & 11 & 35 & $\begin{array}{l}\text { W.S. Central } \\
\text { Austin, TX }\end{array}$ & $\begin{array}{r}1,109 \\
73\end{array}$ & $\begin{array}{r}6 / 9 \\
45\end{array}$ & $\begin{array}{r}278 \\
19\end{array}$ & $\begin{array}{r}92 \\
5\end{array}$ & $\begin{array}{r}29 \\
2\end{array}$ & $\begin{array}{r}31 \\
2\end{array}$ & $\begin{array}{r}34 \\
2\end{array}$ \\
\hline Newark, NJ & 21 & 8 & 5 & 6 & 1 & 1 & 1 & $\begin{array}{l}\text { Austin, IX } \\
\text { Baton Buge IA }\end{array}$ & 11 & $\begin{array}{r}40 \\
9\end{array}$ & 1 & - & & & \\
\hline Paterson, NJ & 14 & 9 & 3 & 2 & - & - & - & Baton Rouge, LA & 11 & & & $\overline{1}$ & 1 & $\overline{-}$ & - \\
\hline Philadelphia, PA & 442 & 249 & 114 & 49 & 18 & 12 & 18 & Corpus Christi, TX & 44 & 25 & 11 & 4 & - & 4 & 5 \\
\hline Pittsburgh, PA§ & 23 & 13 & 9 & - & - & 1 & 1 & Dallas, TX & 152 & 89 & 33 & 18 & 8 & 4 & 5 \\
\hline Reading, PA & 33 & 24 & 4 & 3 & 2 & - & 4 & El Paso, TX & 63 & 34 & 22 & 4 & 2 & 1 & 1 \\
\hline Rochester, NY & 120 & 91 & 20 & 4 & 1 & 4 & 8 & Fort Worth, TX & 94 & 61 & 25 & 4 & 1 & 3 & 一 \\
\hline Schenectady, NY & 21 & 17 & 3 & 1 & - & - & 1 & Houston, TX & 298 & 182 & 78 & 27 & 7 & 4 & 9 \\
\hline Scranton, PA & 32 & 27 & 4 & 1 & - & - & 1 & Little Rock, AR & 52 & 29 & 13 & 2 & 3 & 5 & 2 \\
\hline Syracuse, NY & 93 & 70 & 16 & 5 & 1 & 1 & 8 & New Orleans, LA" & $\mathrm{U}$ & $U$ & $U$ & $\mathrm{U}$ & $U$ & $U$ & $\mathrm{U}$ \\
\hline Trenton, NJ & 21 & 10 & 8 & 3 & - & - & 1 & San Antonio, TX & 183 & 122 & 37 & 16 & 4 & 4 & 5 \\
\hline Utica, NY & 15 & 13 & 1 & - & 1 & - & 2 & Shreveport, LA & 30 & 22 & 7 & - & - & 1 & 2 \\
\hline Yonkers, NY & 18 & 13 & 3 & 2 & - & - & 1 & Tulsa, OK & 109 & 61 & 32 & 12 & 1 & 3 & 3 \\
\hline E.N. Central & 1,649 & 1,084 & 367 & 119 & 43 & 35 & 94 & Mountain & 747 & 466 & 170 & 56 & 28 & 23 & 39 \\
\hline Akron, $\mathrm{OH}$ & 36 & $\begin{array}{r}13 \\
23\end{array}$ & $\begin{array}{r}11 \\
11\end{array}$ & 2 & - & - & $\begin{array}{r}94 \\
1\end{array}$ & Albuquerque, NM & 123 & 81 & 30 & 8 & 2 & 2 & 6 \\
\hline Canton, $\mathrm{OH}$ & 37 & 26 & 6 & 3 & 2 & - & 3 & Boise, ID & 44 & 34 & 6 & 1 & 2 & 1 & 1 \\
\hline Chicago, IL & 282 & 165 & 77 & 25 & 11 & 3 & 19 & Colorado Springs, CO & 47 & 33 & 8 & 2 & 4 & - & 1 \\
\hline Cincinnati, $\mathrm{OH}$ & 74 & 49 & 14 & 5 & 3 & 3 & $\begin{array}{r}19 \\
9\end{array}$ & Denver, CO & 51 & 28 & 13 & 4 & 1 & 5 & - \\
\hline Cleveland, $\mathrm{OH}$ & 171 & 118 & 34 & 12 & 5 & 2 & $\begin{array}{l}9 \\
6\end{array}$ & Las Vegas, NV & 247 & 148 & 70 & 19 & 7 & 3 & 18 \\
\hline Columbus, $\mathrm{OH}$ & 133 & 91 & 34 & 7 & - & 5 & 6 & Ogden, UT & $U$ & $\mathrm{U}$ & U & $U$ & U & U & U \\
\hline Dayton, $\mathrm{OH}$ & $\begin{array}{r}100 \\
98\end{array}$ & 70 & 18 & 9 & $\overline{1}$ & - & $\begin{array}{l}6 \\
4\end{array}$ & Phoenix, AZ & 96 & 52 & 17 & 11 & 5 & 7 & 5 \\
\hline Detroit, Ml & $\begin{array}{r}90 \\
149\end{array}$ & 77 & $\begin{array}{l}10 \\
44\end{array}$ & 13 & 11 & $\overline{4}$ & $\begin{array}{l}4 \\
9\end{array}$ & Pueblo, CO & 29 & 20 & 7 & 2 & - & - & 2 \\
\hline Evansville, IN & 41 & 33 & 6 & - & 2 & 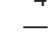 & 3 & Salt Like City, UT & 110 & 70 & 19 & 9 & 7 & 5 & 6 \\
\hline Fort Wayne, IN & 49 & 35 & 10 & $\overline{1}$ & - & $\overline{3}$ & $\underline{3}$ & Tucson, AZ & U & $U$ & U & U & $U$ & $U$ & $U$ \\
\hline Gary, IN & 12 & 11 & - & - & - & 1 & - & Pacific & 1,420 & 962 & 305 & 90 & 36 & 26 & 117 \\
\hline Grand Rapids, MI & 36 & 27 & 6 & 2 & - & 1 & 5 & Berkeley, CA & 14 & 10 & 2 & 1 & - & 1 & 2 \\
\hline Indianapolis, IN & 174 & 106 & 38 & 19 & 4 & 7 & 6 & Fresno, CA & 145 & 90 & 30 & 11 & 11 & 3 & 7 \\
\hline Lansing, MI & 33 & 27 & 5 & 1 & - & - & - & Glendale, CA & 13 & 8 & 3 & 2 & - & - & 2 \\
\hline Milwaukee, WI & 80 & 53 & 21 & 5 & - & 1 & 9 & Honolulu, $\mathrm{HI}$ & 52 & 31 & 15 & 5 & - & 1 & - \\
\hline Peoria, IL & 40 & 29 & 9 & - & 2 & - & 4 & Long Beach, CA & 50 & 22 & 18 & 5 & 2 & 3 & 5 \\
\hline Rockford, IL & 52 & 36 & 10 & 6 & - & - & - & Los Angeles, CA & 245 & 170 & 51 & 10 & 9 & 5 & 34 \\
\hline South Bend, IN & 40 & 25 & 10 & 2 & - & 3 & 2 & Pasadena, CA & 28 & 22 & 3 & 2 & 1 & - & 2 \\
\hline Toledo, $\mathrm{OH}$ & 72 & 52 & 11 & 7 & 1 & 1 & $\overline{6}$ & Portland, OR & 100 & 64 & 26 & 6 & 1 & 3 & 4 \\
\hline Youngstown, $\mathrm{OH}$ & 40 & 31 & 7 & - & 1 & 1 & 2 & Sacramento, CA & 186 & 126 & 35 & 16 & 4 & 5 & 15 \\
\hline W.N. Central & 605 & 412 & 119 & 42 & 12 & 17 & 36 & San Diego, CA & 122 & 83 & 28 & 6 & 3 & 1 & 10 \\
\hline Des Moines, IA & 107 & 81 & 19 & $\begin{array}{r}4< \\
2\end{array}$ & 1 & 2 & 4 & San Francisco, CA & 67 & 41 & 18 & 5 & 2 & 1 & 11 \\
\hline Duluth, MN & 28 & 18 & 8 & 1 & - & 1 & $\begin{array}{l}4 \\
2\end{array}$ & San Jose, CA & 154 & 123 & 26 & 5 & - & - & 13 \\
\hline Kansas City, KS & 26 & 14 & 6 & 5 & 1 & - & 1 & Santa Cruz, CA & 22 & 19 & 3 & - & - & - & 2 \\
\hline Kansas City, MO & 78 & 49 & 16 & 8 & 2 & 3 & 5 & Seattle, WA & 91 & 58 & 19 & 9 & 2 & 3 & 4 \\
\hline Lincoln, NE & 50 & $\begin{array}{l}49 \\
38\end{array}$ & 11 & - & 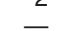 & 1 & $\begin{array}{l}5 \\
7\end{array}$ & Spokane, WA & 52 & 42 & 9 & 1 & - & - & 2 \\
\hline Minneapolis, MN & 48 & $\begin{array}{l}38 \\
26\end{array}$ & 13 & $\overline{5}$ & $\overline{1}$ & $\begin{array}{l}1 \\
3\end{array}$ & $\begin{array}{l}7 \\
3\end{array}$ & Tacoma, WA & 79 & 53 & 19 & 6 & 1 & - & 4 \\
\hline Omaha, NE & 76 & 60 & 11 & 3 & 1 & 1 & 4 & Total & $9,645^{\star *}$ & 6,269 & 2,185 & 719 & 243 & 218 & 542 \\
\hline St. Louis, MO & 99 & 58 & 19 & 12 & 3 & 6 & 6 & & & & & & & & \\
\hline St. Paul, MN & 41 & 31 & 5 & 3 & 2 & - & 3 & & & & & & & & \\
\hline Wichita, KS & 52 & 37 & 11 & 3 & 1 & - & 1 & & & & & & & & \\
\hline
\end{tabular}

\section{$\mathrm{U}$ : Unavailable. - No reported cases.}

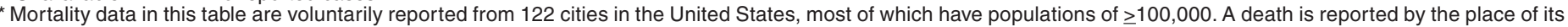
occurrence and by the week that the death certificate was filed. Fetal deaths are not included.

† Pneumonia and influenza.

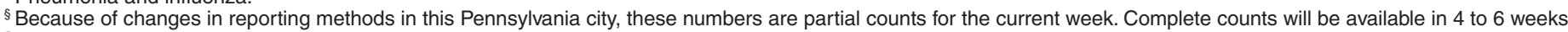

"Because of Hurricane Katrina, weekly reporting of deaths has been temporarily disrupted.

** Total includes unknown ages. 
FIGURE I. Selected notifiable disease reports, United States, comparison of provisional 4-week totals September 9, 2006, with historical data

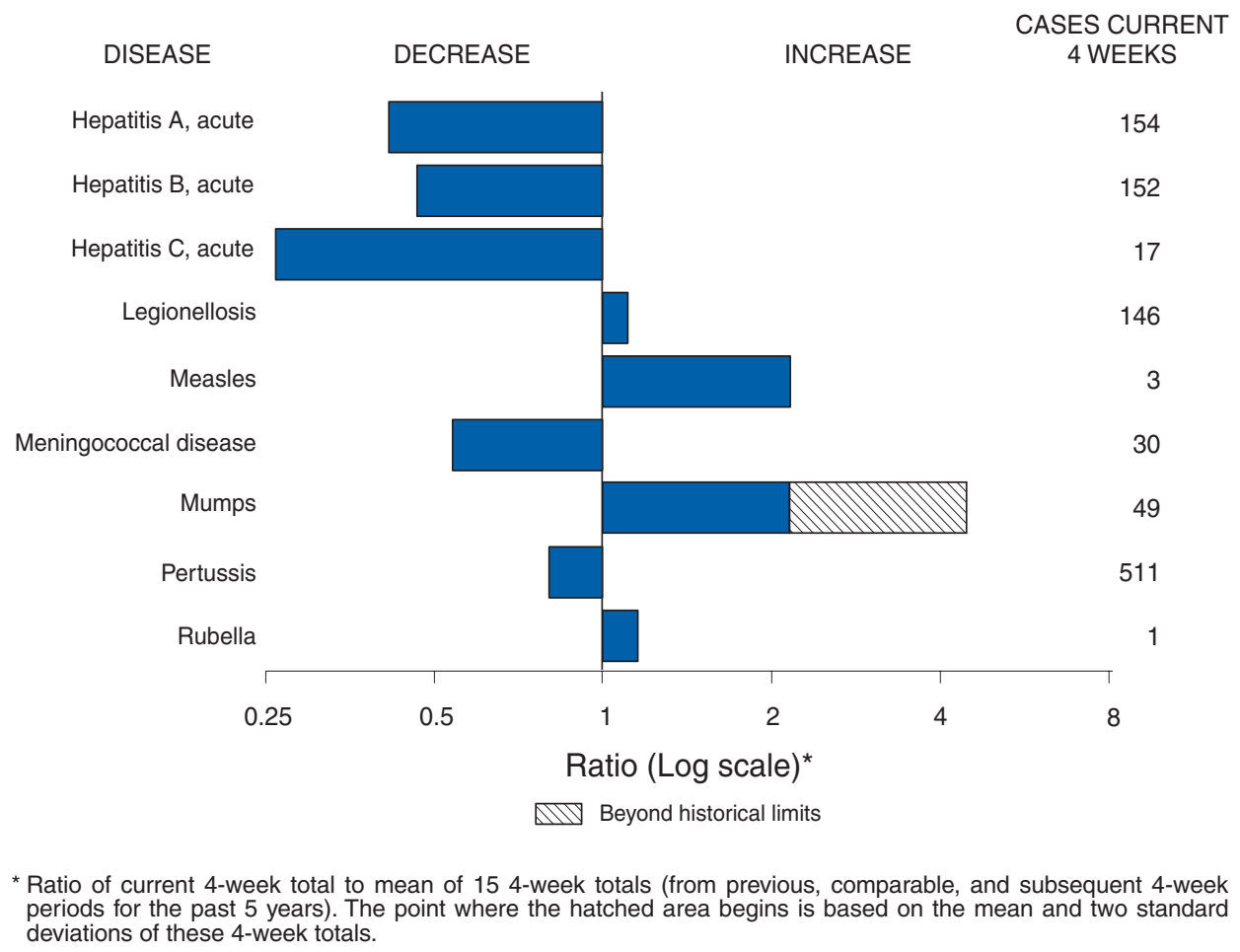

Notifiable Disease Morbidity and 122 Cities Mortality Data Team Patsy A. Hall

Deborah A. Adams Rosaline Dhara

Willie J. Anderson Vernitta Love

Lenee Blanton Pearl C. Sharp 
Vol. 55 / No. 36 
The Morbidity and Mortality Weekly Report (MMWR) Series is prepared by the Centers for Disease Control and Prevention (CDC) and is available free of charge in electronic format. To receive an electronic copy each week, send an e-mail message to listserv@listserv.cdc.gov. The body content should read SUBscribe mmwrtoc. Electronic copy also is available from CDC's Internet server at http://www.cdc.gov/mmwr or from CDC's file transfer protocol server at $f t p: / / f t p . c d c$. gov/pub/ publications/mmwr. Paper copy subscriptions are available through the Superintendent of Documents, U.S. Government Printing Office, Washington, DC 20402; telephone 202-512-1800.

Data in the weekly MMWR are provisional, based on weekly reports to CDC by state health departments. The reporting week concludes at close of business on Friday; compiled data on a national basis are officially released to the public on the following Friday. Data are compiled in the National Center for Public Health Informatics, Division of Integrated Surveillance Systems and Services. Address all inquiries about the MMWR Series, including material to be considered for publication, to Editor, MMWR Series, Mailstop E-90, CDC, 1600 Clifton Rd., N.E., Atlanta, GA 30333 or to www.mmwrq@cdc.gov.

All material in the MMWR Series is in the public domain and may be used and reprinted without permission; citation as to source, however, is appreciated.

Use of trade names and commercial sources is for identification only and does not imply endorsement by the U.S. Department of Health and Human Services.

References to non-CDC sites on the Internet are provided as a service to $M M W R$ readers and do not constitute or imply endorsement of these organizations or their programs by CDC or the U.S. Department of Health and Human Services. CDC is not responsible for the content of these sites. URL addresses listed in $M M W R$ were current as of the date of publication. 